\title{
THESIS
}

\section{RIFT TO DRIFT TRANSITION IN THE SOUTHWEST AUSTRALIAN DEEPWATER MENTELLE BASIN}

\author{
Submitted by \\ Emmanuel Guerzon \\ Department of Geosciences
}

In partial fulfillment of the requirements

For the Degree of Master of Science

Colorado State University

Fort Collins, Colorado

Summer 2021

Master's Committee:

Advisor: Dennis Harry

Lisa Stright

Joseph Scalia IV 
Copyright by Emmanuel Guerzon 2021

All Rights Reserved 


\section{ABSTRACT}

RIFT TO DRIFT TRANSITION IN THE SOUTHWEST AUSTRALIAN DEEPWATER MENTELLE BASIN

The Mentelle Basin is a deepwater polyphase basin located off of the southwest margin of Australia that formed during Late Jurassic and Early Cretaceous breakup of Gondwana. It is underlain by highly extended continental crust and is bordered to the west by less extended crust forming the Naturaliste Plateau, and to the east by the Yalingup Shelf and Perth Basin beneath the continental shelf and coastal plain. The purpose of this study is to characterize the depositional, subsidence, and tectonic histories of the Mentelle Basin during the syn-rift to post-rift transition period. We use seismic reflection data and boreholes drilled by the Deep Sea Drilling Project and International Ocean Discovery Program (IODP) to map three horizons and intermittent volcanic features within this $>134 \mathrm{Ma}$ to $126 \mathrm{Ma}$ period. The youngest horizon mapped was the top of Lithostratigraphic Unit 5 (LSU5) at IODP Site U1513, which corresponds with the lower Aptian age (126 Ma) when rifting on this part of the margin ended and seafloor spreading began between Greater India and Australia west of the Naturaliste Plateau. Also mapped was a reflector encountered at the top of the basalt pile in IODP Hole U1513D at the western edge of the Mentelle Basin. The oldest horizon mapped is the Valanginian Unconformity that lies below this basalt pile and corresponds with breakup and the onset of seafloor spreading on the Perth Abyssal Plain further north. Isochore maps and two depth structure maps generated from these horizons illustrate 
the subsidence history and structural and magmatic evolution of the Mentelle Basin during breakup.

Syn-rift magmatism in the Mentelle Basin was more widespread than previously thought. While earlier studies deemed the western half of the Mentelle Basin magmatic, the eastern extent of magmatism was unknown. Seismic correlation of the basalt reflector at Site U1513 indicates the Naturaliste Plateau basalts extended eastward to the eastern flank of the Mentelle Basin. Younger flows $2-20 \mathrm{~km}$ wide and occasional volcanic cones ranging from $0.5-2.5 \mathrm{~km}$ wide are imaged in the western half of the basin to the toe of the eastern slope. These younger volcanic features were emplaced between the late Valanginian through the start of the Aptian age. Basalt flows and some volcanic features in the basin are interpreted to have been exposed and weathered at or above sea level around the time of emplacement before subsequent burial by a marine transgression. The Mentelle Basin began to subside prior to the Naturaliste Plateau (> $134 \mathrm{Ma}$ ) as rifting occurred between India and Australia-Antarctica. Once final breakup occurred and seafloor spreading began west of the Naturaliste Plateau, both the Mentelle Basin and Naturaliste Plateau subsided to bathyal depths beginning around $126 \mathrm{Ma}$. 


\section{TABLE OF CONTENTS}

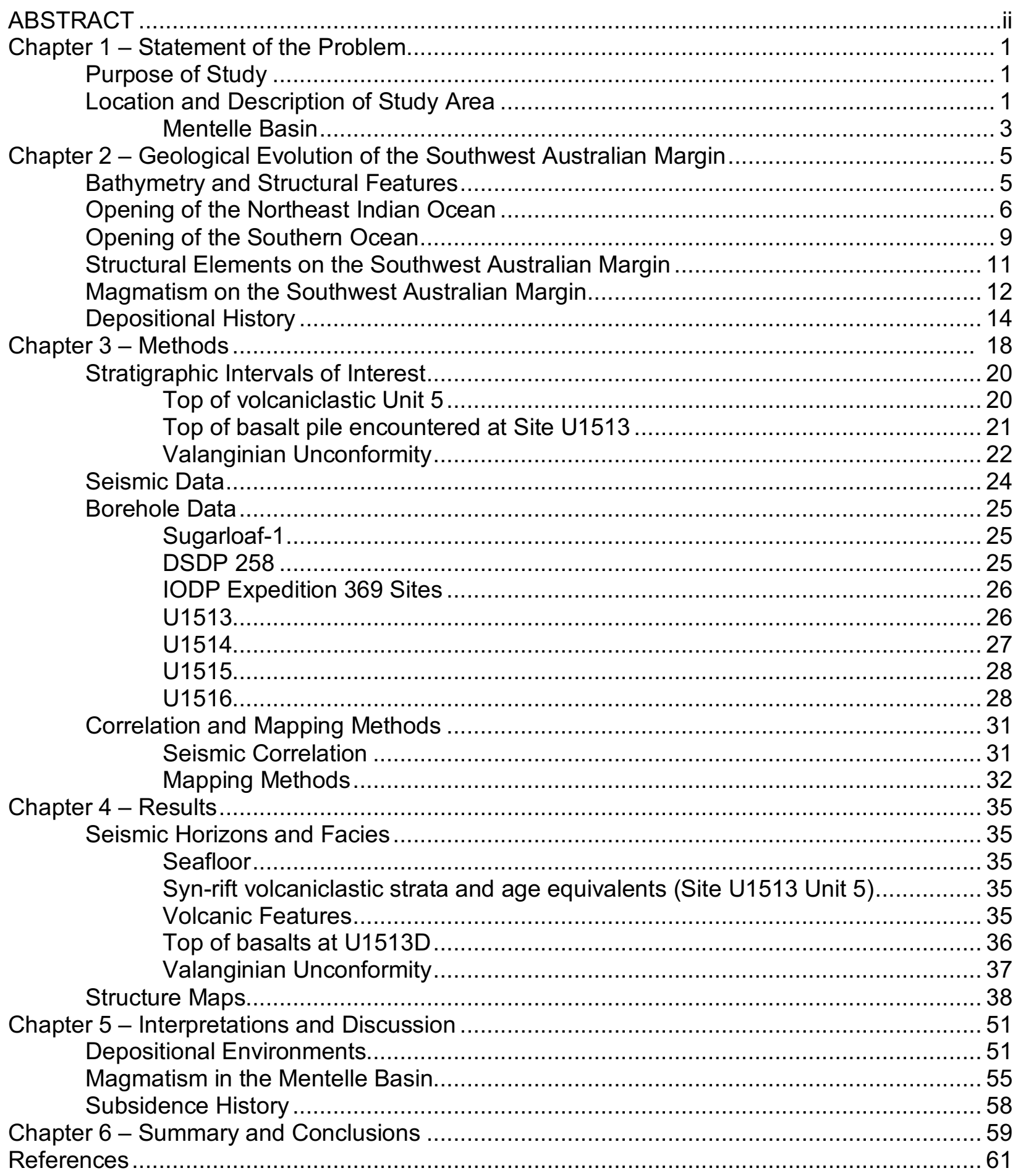




\section{CHAPTER I: STATEMENT OF THE PROBLEM}

\section{Purpose of Study}

The opening of the northeast Indian Ocean is reasonably well constrained by marine magnetic anomalies, but the relationship between rifting, subsidence, sedimentation, and magmatism during the late stages of rifting and immediately after breakup is not well understood. This is especially true on the southwest Australian continental margin, where the deepwater Mentelle Basin formed over highly extended crust west of the continental shelf. The Mentelle Basin stratigraphic record contains an interval deposited between the Valanginian (139 +/- $3.0 \mathrm{Ma})$ and Aptian (126 Ma) ages, which was a transitional period along the southwest Australian margin. This interval encompasses when the margin transitioned from volcanically active to inactive, shallow depths to deep water, and syn-rift to post-rift conditions.

This thesis will focus on the Valanginian through Aptian stratigraphic interval in the Mentelle Basin to understand the timing, pattern, and tectonic causes of subsidence in the basin. This will give us insight to the processes occurring during the time of East Gondwana breakup and opening of the northeast Indian Ocean.

\section{Location and Description of Study Area}

Located in the northeast Indian Ocean, the western Australian margin was formed by continental rifting during the Late Jurassic through the Early Cretaceous period. The continental shelf is underlain by the well-explored Perth Basin, which is a polyphase rift basin that exploited structural trends created during an earlier Permian extensional episode. The Perth Basin and continental shelf in the central part of the western Australian margin are bordered by the Perth Abyssal Plain (PAP; Fig. 1). The PAP is underlain by oceanic crust, with the oldest crust 
corresponding with seafloor spreading magnetic anomaly chron M11 (132 Ma) (Gibbons et al., 2012). To the northwest of the margin lies the Wallaby Plateau (WP), separated from the margin by extended continental crust beneath the Wallaby Saddle, as well as oceanic crust corresponding with chrons M14 - M11 (136 - 132 Ma) (Mihut and Muller, 1998). The Wallaby Plateau has a core of continental crust, which was later intruded by magma around the time seafloor spreading began (Symonds et al., 1998). Just northwest of the WP lies the Zenith Plateau, which like the Wallaby Plateau consists of continental crust overlain by $136-132 \mathrm{Ma}$ basaltic flows (Planke et al., 2002). On the southwest Australian margin lies the deepwater Late Jurassic - Early Cretaceous Mentelle Basin (MB), and to its west lies the Naturaliste Plateau (NP). Based on the seismic velocity structure (Direen et al., 2007), the NP is thought to be a fragment of continental crust which, like the WP and ZP separated from Australia during the early stages of opening of the Indian Ocean (Gibbons et al., 2012). West of the NP is oceanic crust whose age is estimated to correspond with chrons M5n or M3n (126 - 124 Ma) (Müller et al., 2000; Gibbons et al., 2012). The MB and NP are bordered to the north by a transform margin that separates them from the PAP and are bordered to the south by a poorly constrained transtensional margin that separates the two features from Cenozoic oceanic crust in the Southern Ocean created during Cretaceous rifting (Weaver et al., 1994). 


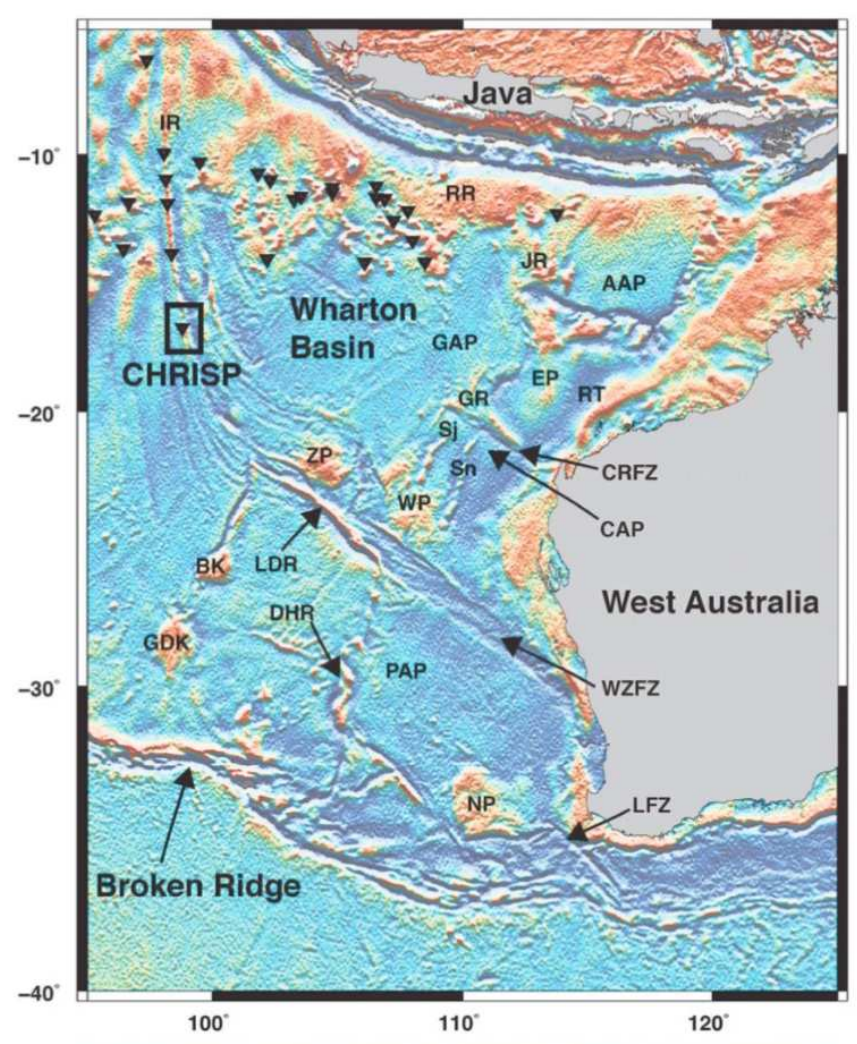

Figure 1. Western Australian margin with labelled offshore features. Shown are the locations of the Naturaliste Plateau (NP), Leeuwin Fracture Zone (LFZ), Perth Abyssal Plain (PAP), Dirk Hartog Ridge (DHR), Wallaby-Zenith Fracture Zone (WZFZ), Gulden Draak Knoll (GDK), Batavia Knoll (BK), Lost Dutchmen Ridge (LDR), Zenith Plateau (ZP), Wallaby Plateau (WP), Sonne Ridge (Sn), Sonja Ridge (Sj), Galah Rise (GR), Exmouth Plateau (EP), Rankin Trend (RT), Argo Abyssal Plain (AAP), Joey Rise (JR), Roo Rise

$(R R)$, and Investigator Ridge (IR). Area in black box in the NW of the figure is the location of the CHRISP 2008 seamount dredge samples. Figure from Gibbons et al., 2012 with bathymetry from Sandwell and Smith, 2009.

\section{Mentelle Basin}

This study focuses on the Mentelle Basin, which is a deepwater polyphase basin covering $36,400 \mathrm{~km}^{2}$. As mentioned above, the MB is bordered to the west by the NP, and bordered to the east by the Yallingup Shelf, which is a basement structural high separating the MB from the Vlaming Sub-basin in the southern Perth Basin (PB) (Fig. 2). The eastern MB lies in water depths from $500-2000 \mathrm{~m}$ and contains up to $1 \mathrm{~km}$ of post-rift strata above the breakup unconformity (Borissova et al., 2010). The western MB lies in water depths of $2000-4000 \mathrm{~m}$ and contains up to $2.7 \mathrm{~km}$ of post-rift strata (Borissova et al., 2010). The greatest total sediment thickness is located in the western MB as well, totaling $10-11 \mathrm{~km}$ (Borissova et al., 2010). 
The onset of extension in the MB is not well constrained. Deep divergent seismic reflections below the inferred breakup unconformity could be interpreted as syn-rift fill, indicating the MB could have formed coevally with Perth Basin extension and breakup (chrons M11r - M11n, 133 - $132 \mathrm{Ma}$ ). Alternatively, the deep divergent reflections may represent deposits from the older Permian phase of extension (as is observed in the Vlaming Sub-basin). In this case, the MB could post-date PB extension, representing a new basin that started to form after seafloor spreading began in the PAP. The southern PB also contains the Bunbury basalts, which are coeval with extension in the southernmost PAP. Basalts of similar age and composition are present on the NP (Direen et al., 2017; Huber et al., 2019), but the presence and extent of volcanism in the central and eastern MB is unknown.

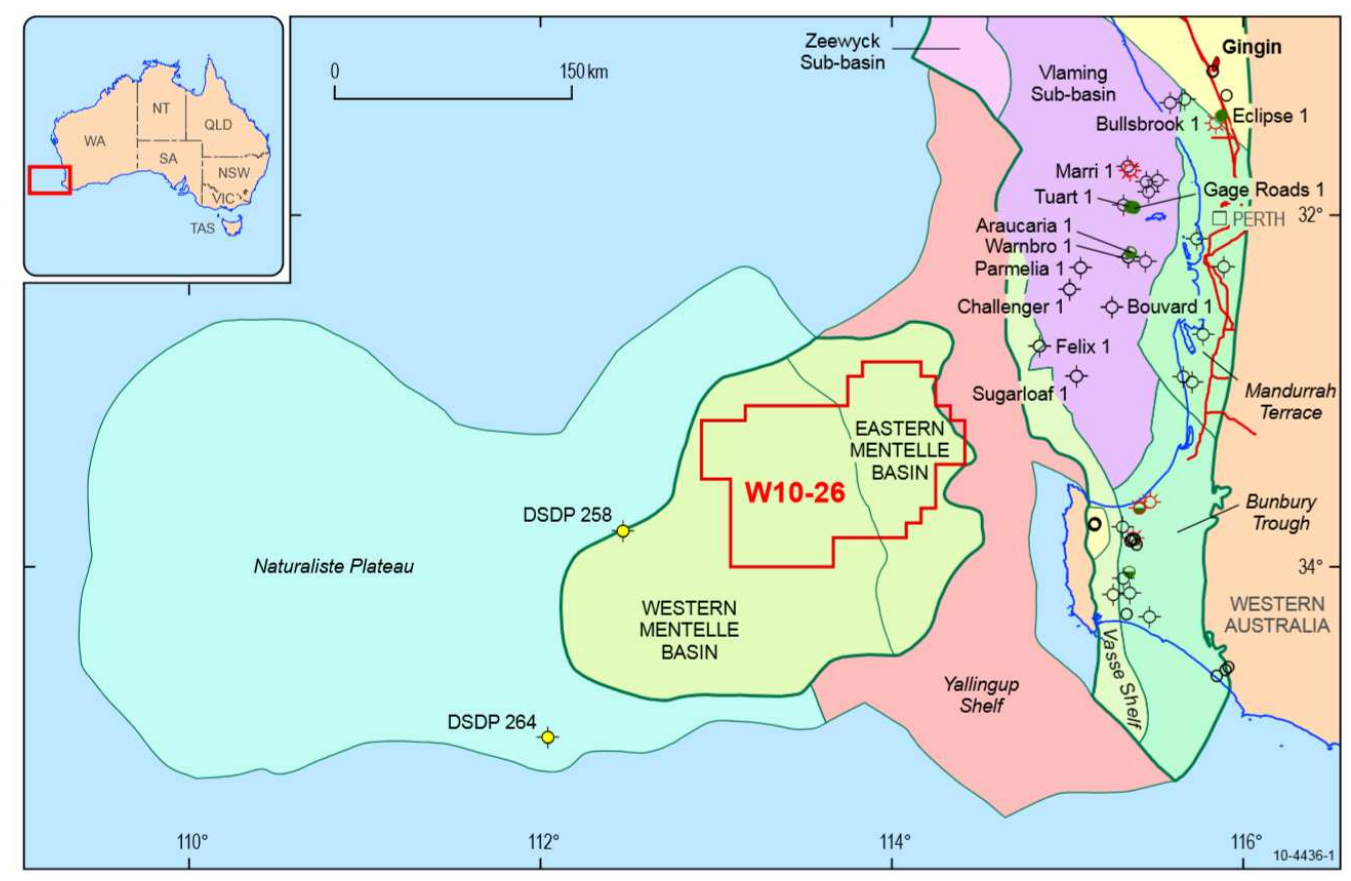

Figure 2. Zoomed in view around the Mentelle Basin on the SW Australian margin, Borissova et al., 2010. Deepwater features of interest in this study include (from W to E) the moderately extended Naturaliste Plateau and highly extended Mentelle Basin. These are bordered to the east by the Yallingup Shelf (a structural high underlaying the morphological shelf) and the inboard Perth Basin. 


\section{CHAPTER II: GEOLOGICAL EVOLUTION OF THE SOUTHWEST AUSTRALIAN MARGIN}

\section{Bathymetry and Structural Features}

Located on the continental shelf off of southwest Australia is the Vlaming Sub-basin (Fig. 2).

This sub-basin lies in the southernmost reaches of the Perth Basin, and has been well studied by petroleum industry drilling and seismic surveys. The final phase of rifting in this basin occurred during the Late Jurassic through Early Cretaceous as Greater India separated from Australia (Lech et al., 2016). To the west of the Vlaming Sub-basin is the basement high of the Yallingup Shelf, which is a relatively unextended block of continental crust laying beneath the shelf edge (Fig. 3). Northward on the central western Australian margin, continental crust comprising the Yallingup Shelf borders $131 \mathrm{Ma}$ (chron M10n) oceanic crust on the central Perth Abyssal Plain. The Yallingup Shelf plunges northward and disappears, so the deepwater central PAP transitions from extended continental crust beneath the Perth Basin to $131 \mathrm{Ma}$ oceanic crust. West of the Yallingup Shelf is extended continental crust underlying the deepwater MB and the adjacent Naturaliste Plateau (Fig. 3). The NP is a fragment of continental crust located roughly $170 \mathrm{~km}$ west of the Australian mainland (Direen et al., 2017). It is roughly $250 \mathrm{~km}$ by $400 \mathrm{~km}$ and covers an area of about $90000 \mathrm{~km}^{2}$. The NP has been suggested to consist of a lower - middle crust extensional allochthon formed during Cretaceous rifting between Antarctica and Australia, overlain by Cretaceous-age volcanics (Halpin et al., 2008).

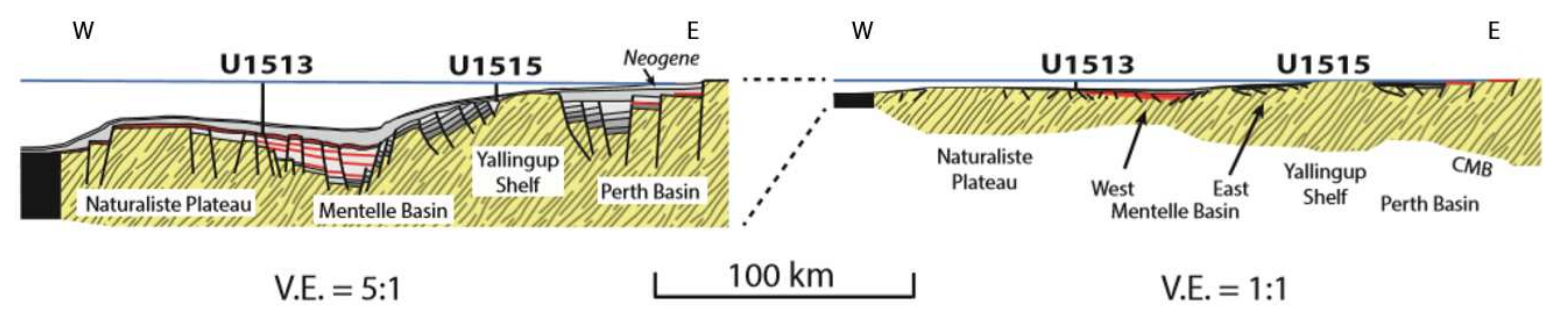

Figure 3. Present-day cross section of the Mentelle Basin and surrounding features, modified from Harry et al., 2020. 


\section{Opening of the Northeast Indian Ocean}

A Permian rifting episode occurred on the margin between $300-265 \mathrm{Ma}$ (Fig. 4a). This was part of a rifting episode that spanned much of the supercontinent of Gondwana, creating rift branches between Greater India, Australia, and Antarctica (Yeates et al., 1987; Harrowfield et al., 2005; Veevers, 2006; Maritati et al., 2020). This was followed by a tectonically quiet period with minor regional subsidence that lasted until the Middle Jurassic (Plumb, 1979; Norvick, 2004), when West and East Gondwana began to separate and rifting resumed between Africa, India, and the combined Australia-Antarctica continent (Fig. 4b) (Norton \& Sclater, 1979; Besse

\& Courtillot, 1988; C.M. Powell et al., 1988; Royer \& Sandwell, 1989; Lawver et al., 1992). This final extensional episode began around $165 \mathrm{Ma}$ and resulted in counter-clockwise rotation of India away from Australia-Antarctica (C.M. Powell et al., 1988; Lawver et al., 1992; Direen et al., 2008, 2011; Ball et al., 2013; Gibbons et al., 2013). The NP at this time was located on the northeast side of the soon-to-be triple junction of the Indian, Australian, and Antarctic plates. The smaller continental fragments of the Batavia and Gulden Draak Knoll were located north and southwest of the NP, respectively (Gibbons et al., 2013; Williams et al., 2013; Whittaker et al., 2016). At $136 \mathrm{Ma}$, there was a reorganization of the spreading system, which created a triple junction between the three plates (Gibbons et al., 2012). Between 132 - $131 \mathrm{Ma}$, seafloor spreading began between Australia and Greater India on the Cuvier Abyssal Plain on the northwest Australian margin (Markl, 1978; Fullerton et al., 1989; Heine \& Müller, 2005; Robb et al., 2005; Gibbons et al., 2012). The Perth Abyssal Plain breakup event was coeval with seafloor spreading on the Cuvier Abyssal Plain, or occurred soon after, as it was also underway by $132-131 \mathrm{Ma}$ (chrons M11n - M10N). This spreading began while the MB and NP were still extending, but seafloor spreading eventually developed west of the Naturaliste Plateau (126 $124 \mathrm{Ma}$ ), connecting the India-Australia and India-Antarctica rift segments (Fig. 4c and 4d). Seafloor spreading propagated southward down the Australian margin, and by $130 \mathrm{Ma}$, India 
had separated from Australia and Antarctica (Gaina et al., 2007; Gibbons et al., 2012). Seafloor spreading was established west of the NP 126 - 124 Ma (chron M5n - M3n) following westward migration of the PAP spreading center across the northern NP transform margin (Gibbons et al., 2012). Following final NP/India breakup, Greater India continued moving westward relative to Australia until 100 Ma (Gibbons et al., 2012), but left behind the Gulden Draak and Batavia Knolls on the Australian Plate due to a ridge jump around $108 \mathrm{Ma}$ (Williams et al., 2013; Whittaker et al., 2016) (Fig. 4d and 4e). There was a global plate reorganization at 100 Ma that led to reorientation of the Indian Ocean spreading system, followed by rapid movement of India northward towards its present-day position (Müller et al., 2000; Veevers, 2006). 


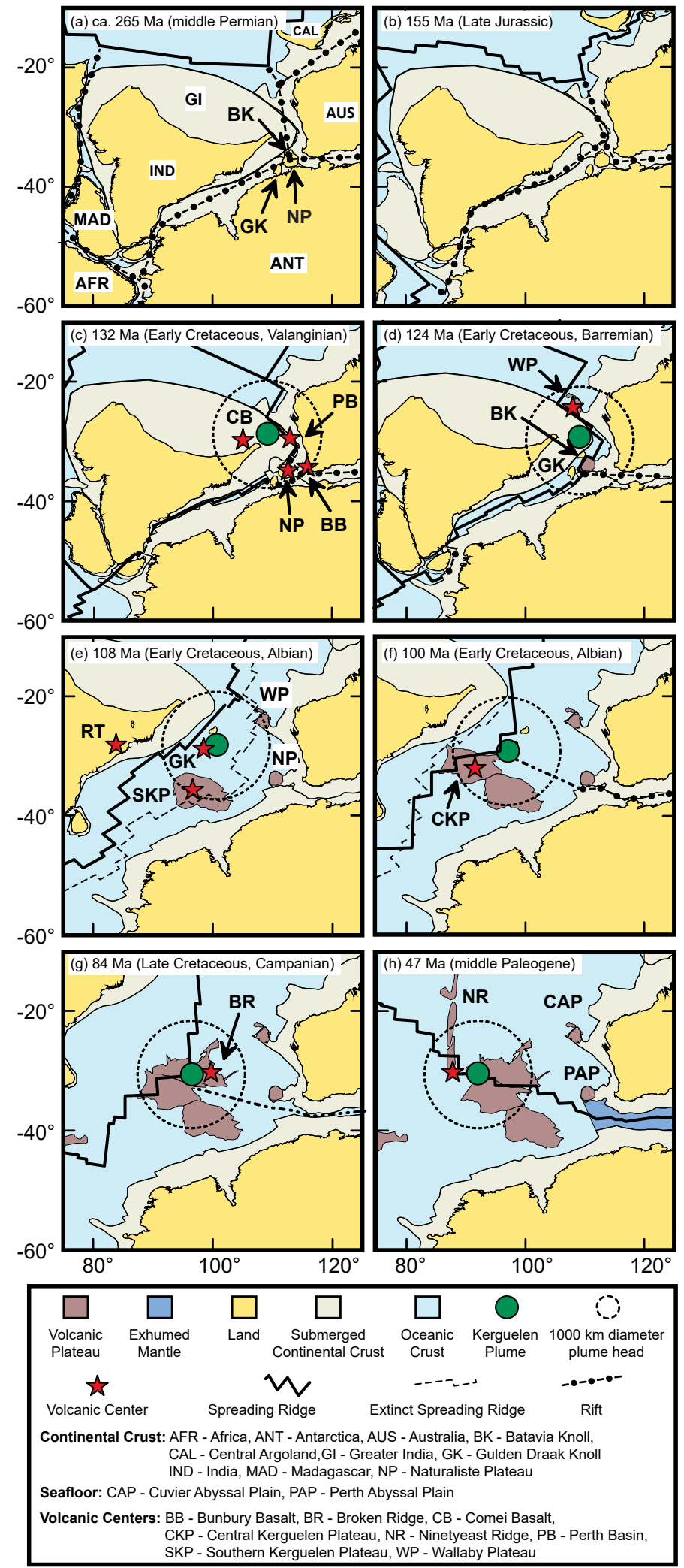

Figure 4. Plate reconstruction and tectonic history from Harry et al., 2020. 


\section{Opening of the Southern Ocean}

Extension between Australia and Antarctica began around $165 \mathrm{Ma}$ (Fig. 5a) (White et al., 2013),

followed by seafloor spreading that propagated west to east between $80-45 \mathrm{Ma}$ (Fig. $5 \mathrm{~d}$ )

(Totterdell et al., 2000; Direen et al., 2012). Seafloor spreading occurred very slowly at a rate of $\sim 5 \mathrm{~mm} /$ year between $80-45 \mathrm{Ma}$, then accelerated to $\sim 22 \mathrm{~mm} /$ year (Mutter et al., 1985), as Australia migrated north relative to Antarctica (Fig. 5e). Australia completely separated from Antarctica by 34 Ma (White et al., 2013) and advanced to its present-day position (Fig. 5f). 

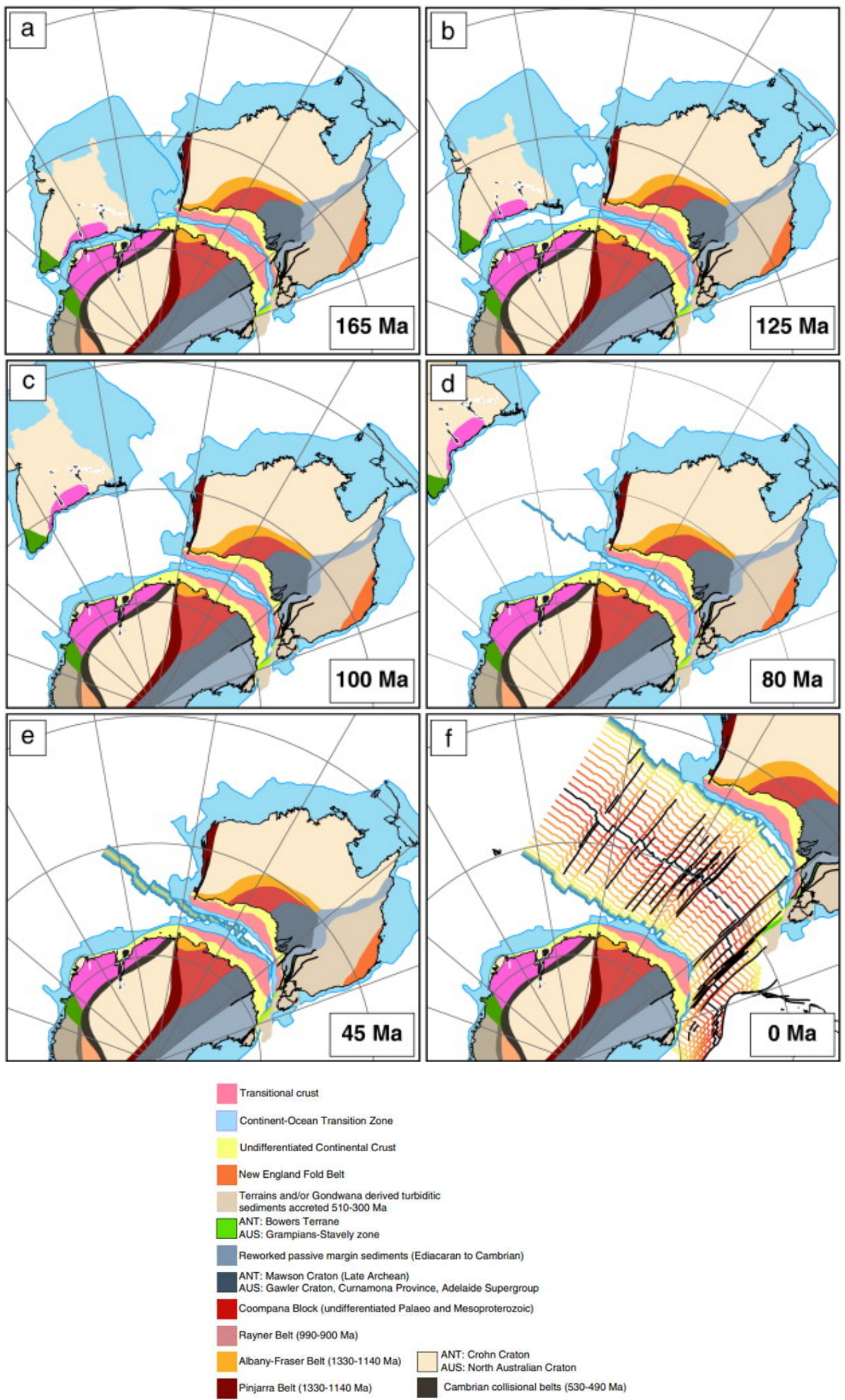

Figure 5. Rift propagation and seafloor spreading between Australia and Antarctica from White et al., 2013. 


\section{Structural Elements on the Southwest Australian Margin}

The Darling Fault is a long-lived feature that separates the Archean (Kinny et al., 1996) Yilgarn Craton from Phanerozoic structures on the west Australian rifted margin (Fig. 6). It is a nearly linear fault that has experienced several episodes of strike-slip and vertical motion at least since the Late Permian (Veevers, 2006). West of the Darling Fault lies the Perth Basin, which is a $1300 \mathrm{~km}$ long polyphase basin that follows the trend of northwest-striking faults that initially formed during a Late Permian extensional episode (Crostella and Backhouse, 2000) (Fig.6). It contains up to $15 \mathrm{~km}$ of late Paleozoic, Mesozoic, and Cenozoic strata (Yeates et al., 1987; Harris, 1994; Song \& Cawood, 2000; Norvick, 2004). Underlying the Perth Basin is the Mesoproterozoic Pinjarra Orogen, which formed when Greater India and Australia amalgamated during the assembly of Gondwana (Markwitz et al., 2017). West of the Perth basin in the central region of the margin are the Houtman and Zeewyck sub-basins, which are separated from the Perth Abyssal Plain oceanic crust by a structural high marking the ocean-continent transition zone (Bradshaw et al., 2003). The Yallingup Shelf, which is a structural high underlain by continental crust, borders the Perth Basin to the west on the southern end of the southwest Australian margin, and is east of the MB. The basement rock underneath the MB is thought to be of similar composition to Mesoproterozoic metasedimentary rocks and orthogneiss that were dredged from the southern NP further west, although it is unknown how much Late Mesozoic syn-rift strata may also be present in the basement. The deep basement rocks dredged from the NP have been correlated with outcrops from the Albany-Fraser-Wilkes orogen on the southern Australian margin and conjugate Antarctica margin (Halpin et al., 2008, 2020). Similar basement rocks presumably underlay syn-rift deposits within the MB. 


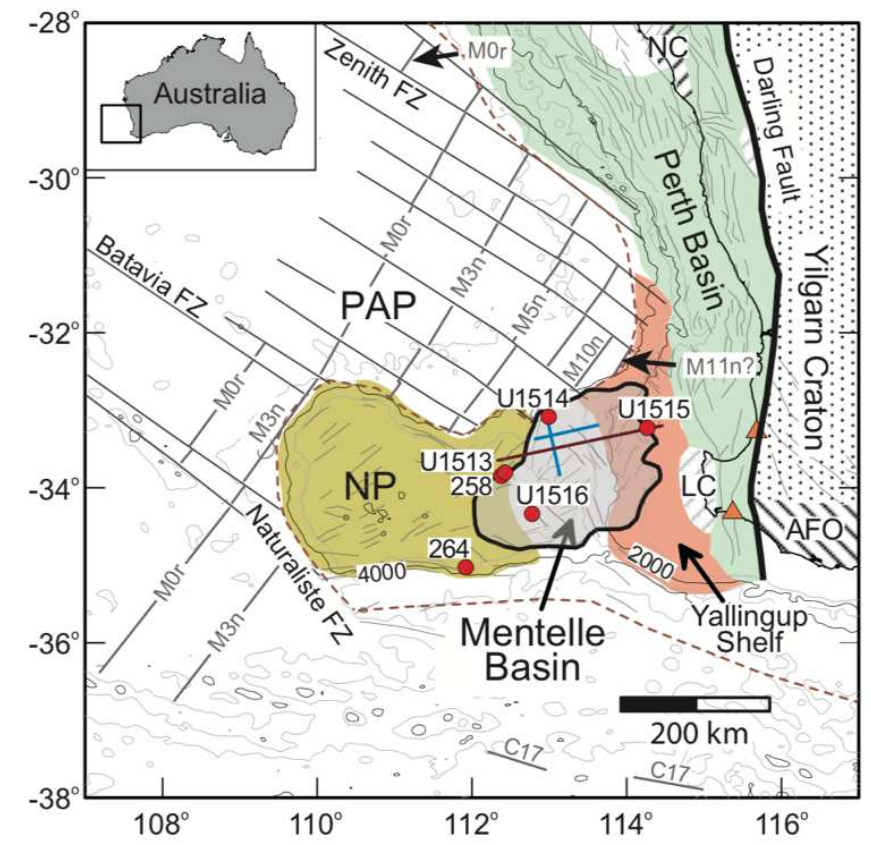

Figure 6. Southwest Australian margin and more of the structural features from Harry et al., 2020. Labels indicate DSDP Sites 258 and 264, and IODP Sites U1513-U1516.

\section{Magmatism on the Southwest Australian Margin}

The extent and role of magmatism on the southwest Australian margin is not well understood. Syn-rift magmatic activity is evidenced by the Bunbury basalts, which have been encountered in the southern Perth Basin boreholes as well as outcrop onshore (Crostella and Backhouse, 2000; Borissova, 2002), and in basalt flows encountered in the western MB at IODP Site U1513 (Huber et al., 2019b). Dating of the U1513 basalts and the basalts encountered in the Perth Basin show that they were emplaced during syn-rift time, between 137 and 130 Ma (Olierook et al., 2016). The basalts present on the NP (131 - 128 Ma) (Direen et al., 2017; Olierook et al., 2016) have been interpreted in the seismic data to extend into the western Mentelle Basin.

However, basalts have not been encountered further north in the central Perth Basin adjacent to the PAP, and there is no evidence of seaward dipping reflectors or strong magnetic anomalies in this area suggesting abundant magmatism at the time of breakup. Seaward dipping reflectors 
interpreted to be volcanic flows are present in the northern Perth Basin (Colwell et al., 1994; Symonds et al., 1998; Borissova, 2002; Bradshaw et al., 2003; Norvick, 2004; Goncharov \& Nelson, 2012; Owens et al., 2018), suggesting this portion of the Australian margin was magmatic during breakup. There is also a thick cap of volcanics on the Wallaby Plateau (Olierook et al., 2015) on the northwest end of the western Australian margin. These basalts are aged at $124 \mathrm{Ma}$ and thereby post-date rifting. There are suggested Bunbury Basalt equivalents seen in other regions, such as the 132 Ma Comei basalts in southeastern Tibet, which would have been the conjugate margin during rifting (Zhu et al., 2009), and the 131-128 Ma NP basalts (Direen et al., 2017; Olierook et al., 2016).

These Bunbury/NP/Comei basalts aged 137 - 128 Ma are petrogenetically similar to the Kerguelen mantle plume basalts seen on the Kerguelen Plateau (>119 - $100 \mathrm{Ma})$, (Whitechurch et al., 1992; Mahoney et al., 1995; Frey et al., 2000; Ingle et al., 2002; Duncan, 2002; Coffin et al., 2002), eastern Indian margin (118 Ma) (Baksi et al., 1987; Baksi, 1995; Kent et al., 2002; Ingle et al., 2004; Zhu et al., 2008), and the Wallaby Plateau (124 Ma) (Olierook et al., 2015). The widely accepted idea is that the large size of the Kerguelen plume head $(\sim 1000 \mathrm{~km})$ and smaller size of the Indian Ocean at the time of eruption account for the modern broad spatial distribution of these basalts (Direen et al., 2017; Olierook et al., 2017; Zhou et al., 2017; Olierook et al., 2016; Zhu et al., 2009; Ingle et al., 2004; Ingle et al., 2002; Kent et al., 2002; Frey et al., 1996; Storey et al., 1989). In this model, the initially large plume head was depleted during the first 10 - $15 \mathrm{Ma}$ after seafloor spreading began in the Indian ocean, with subsequent plume-related volcanism being confined to the Kerguelen Plateau. Another model suggests regional contamination of the upper mantle by the Kerguelen plume head (or other magmatic episodes) prior to the onset of rifting. This enriched fertile mantle was then tapped at different times and places during the rifting process (Harry et al., 2020; Kent et al., 1991; Storey et al., 1989). A third idea, similar to the rising mushroom plume model, is that the Kerguelen plume 
acted as a deep reservoir that fed individual rising columns, which then fed magmatism at various places and times as the Indian Ocean opened (Coffin et al., 2002).

\section{Depositional History}

Underneath the NP and MB is crystalline basement rock, which is likely similar to the granitic basement found underneath the Perth Basin (Crostella and Backhouse, 2000) and Yallingup Shelf. Basement in those areas has been determined from drilling to be part of the Proterozoic Pinjarra Orogen (Bodorkos et al., 2016). Only the post-Cretaceous rift sequence of the Mentelle Basin has been drilled, so the stratigraphy underlying this is inferred from seismic interpretation and geologic knowledge from the nearby Vlaming Sub-basin in the southern Perth Basin. Major sequences were correlated between the MB and Vlaming Sub-basin based on seismic dip and reflection termination patterns (Borissova et al., 2010). Overlying the metamorphic basement Pinjarra Orogen in the Vlaming Sub-basin is the rift sequence from the Permian, which is comprised of sandstone interspersed with coal measures (Fig. 7). This is inferred to correlate with deep stratified reflectors observed below the Valanginian Unconformity in the MB (Borissova et al., 2010). On top of the rift sequence is the tectonically quiescent strata, which in the MB is inferred to correlate with the Late Permian Upper Sue Group, Sabina and Lesueur Triassic sandstones, and Lower Jurassic Cattamarra Coal Measures in the southern Perth Basin (Figs. 7, 8). This Late Permian to Early Jurassic strata was then heavily deformed, faulted, and eroded during the Middle Jurassic - Early Cretaceous rifting episode that led to opening of the Indian Ocean (Borissova et al., 2010). The syn-rift sequence in the Mentelle Basin has been suggested to correlate with the fluvial and marine siliciclastic Middle to Late Yarragadee Formation through Late Jurassic - Early Cretaceous Parmelia Group strata encountered in the Vlaming Sub-basin (Fig. 7) (Borissova et al., 2010). In the Perth Basin, the syn-rift strata are capped by a late Valanginian unconformity interpreted to mark breakup and 
the onset of seafloor spreading on the PAP (Lech et al., 2016). This breakup unconformity is overlain by the syn-and-post-rift Bunbury basalts in the Vlaming Sub-basin. A similar unconformity imaged in MB seismic data has been interpreted to correlate with the Perth Basin Valanginian Unconformity. In the western MB, the Valanginian Unconformity is overlain by a basaltic sequence (correlated to the Bunbury basalts) that interfingers with volcaniclastic sandstone beds encountered at IODP Site U1513 during Expedition 369 (Huber et al., 2019b; Lee et al., 2020; Harry et al., 2020). The Bunbury basalts in the PB are overlain by the deltaic and marine Gage Sandstone and South Perth Shale in the Vlaming Sub-basin (Fig. 8). The post-breakup Cretaceous sequence overlying the basalts and volcaniclastics in the MB is comprised of middle bathyal to bathyal clay and claystone (Fig. 15) (Huber et al., 2019b; Lee et al., 2020, Harry et al., 2020), signifying post-breakup deepwater subsidence of the basin. 


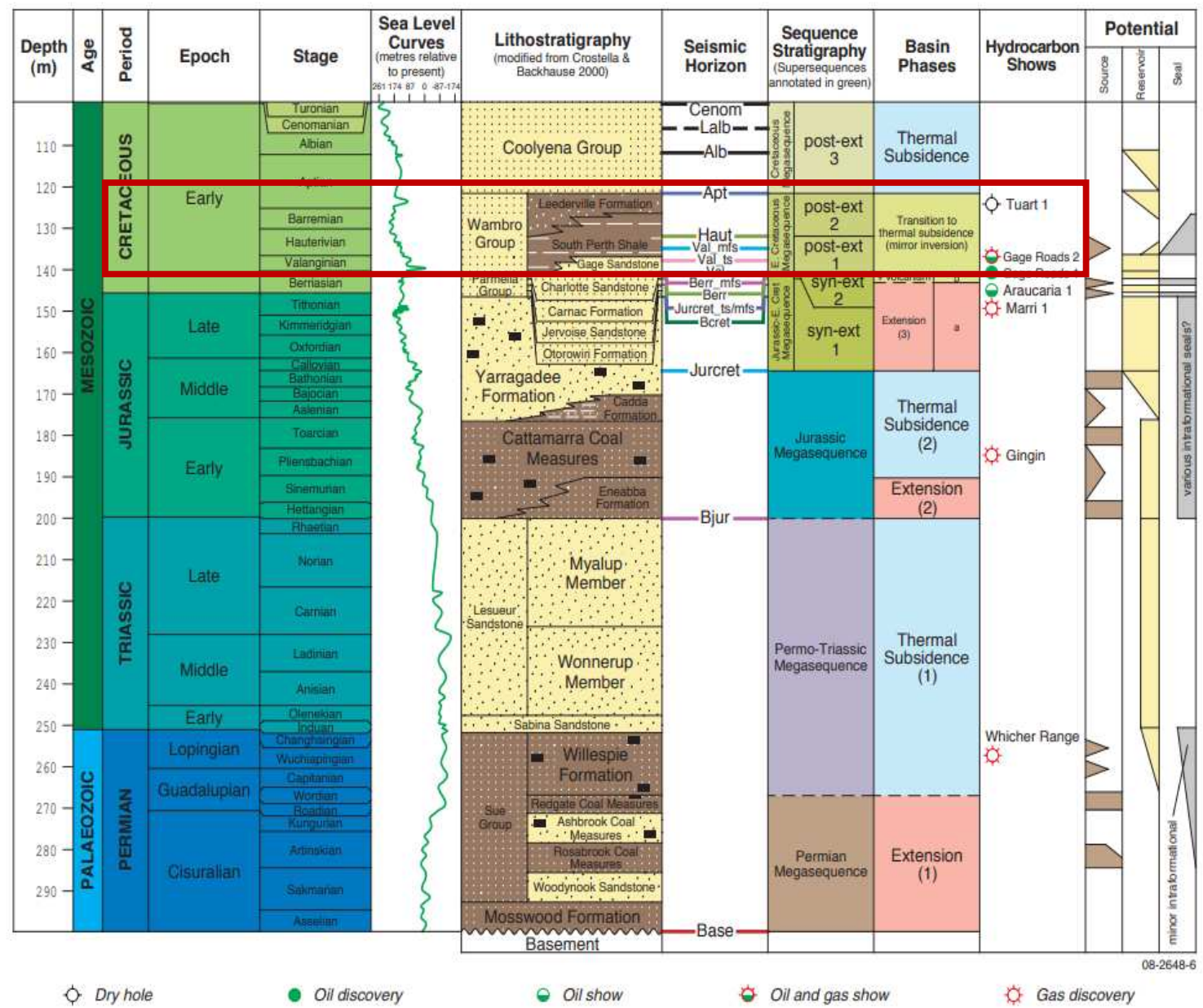

Figure 7. Southern Perth Basin stratigraphy, modified from Nicholson et al., 2008. Red box denotes stratigraphic interval of interest from the Valanginian to Aptian ages (139-126 Ma). 


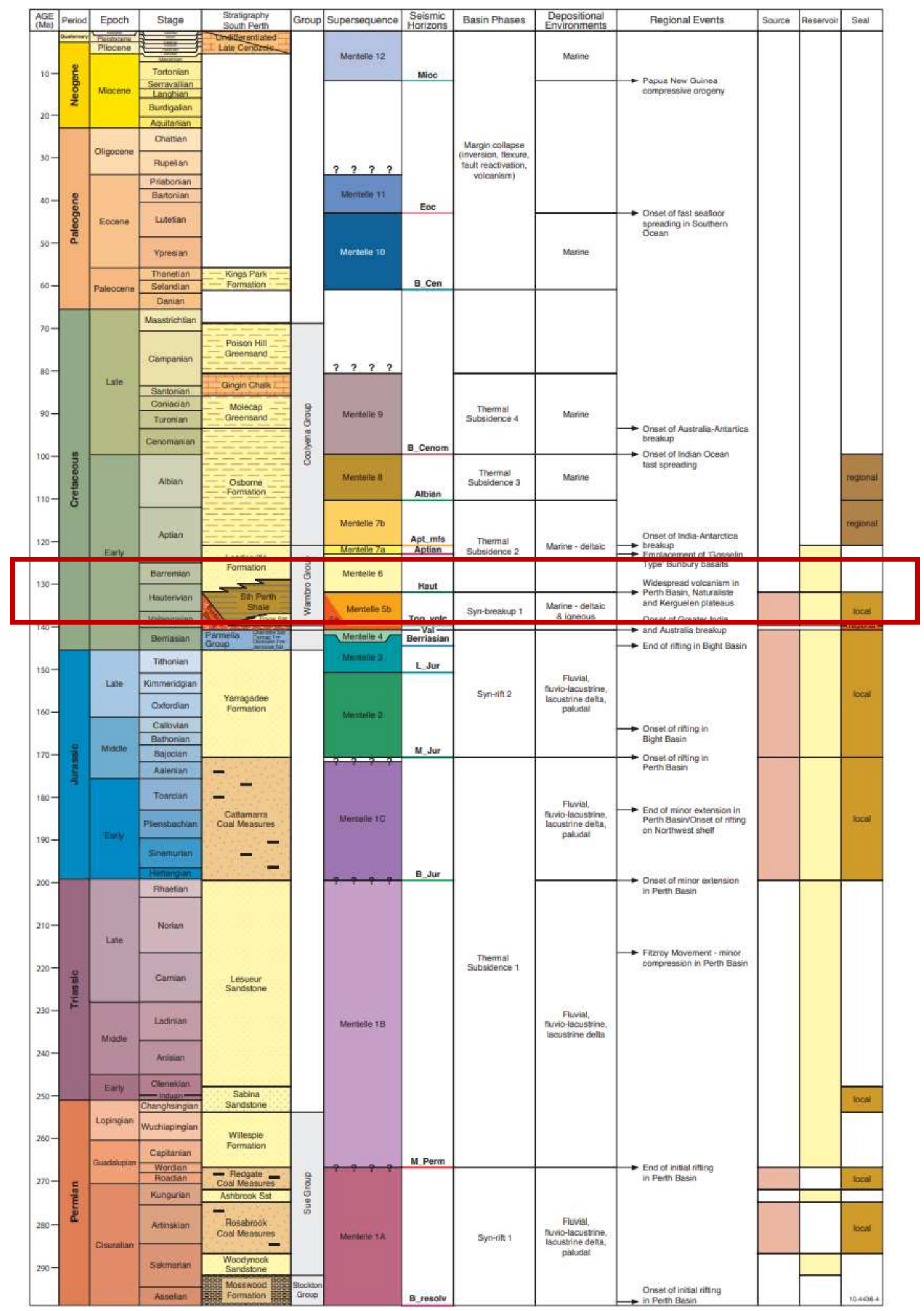

Figure 8. Stratigraphic column of the Mentelle Basin modified from Borissova et al., 2010. Red box denotes stratigraphic interval of interest from the Valanginian to Aptian ages $(139-126 \mathrm{Ma})$. 


\section{CHAPTER III: METHODS}

2D seismic reflection data were used in conjunction with the DSDP and IODP drilling data to create structure and isochore maps of strata deposited immediately before and after breakup on the southwest Australian margin, covering the period of time during which extension continued in the MB after seafloor spreading had begun in the Perth Abyssal Plain. Four horizons were mapped in this period of interest, not including the seafloor (Figs. 9, 10). These include the top of the volcaniclastic sequence that corresponds with the lower Aptian age (126 Ma) (Lee et al., 2020) and laterally time-equivalent strata, the top of the basalts encountered at borehole U1513D, and two possibilities for the Valanginian Unconformity, which correlate with the Perth Abyssal Plain breakup event (133 - $132 \mathrm{Ma})$. 


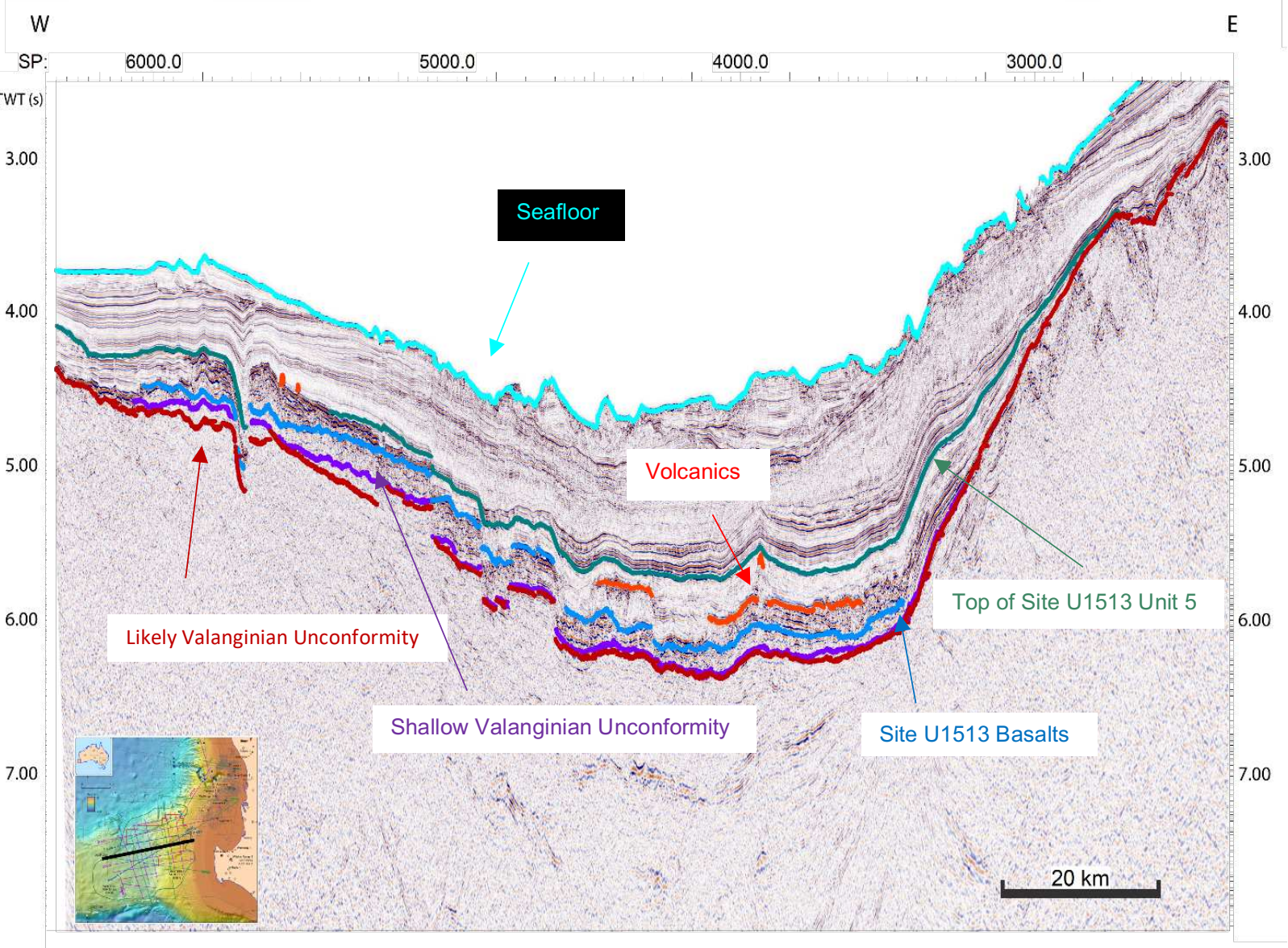

Figure 9. Typical cross section in the time domain through the Mentelle Basin. Line S310_07 from top to bottom: seafloor (turquoise), top of volcaniclastic Unit 5 (dark green), volcanic features (orange), basalts encountered at U1513D (blue), shallow Valanginian Unconformity possibility (purple), likely Valanginian Unconformity (maroon). Y-axis is in two-way travel time (s). Mapped faults are not pictured here for image clarity. Locator map in bottom left modified from Borissova et al., 2010. 


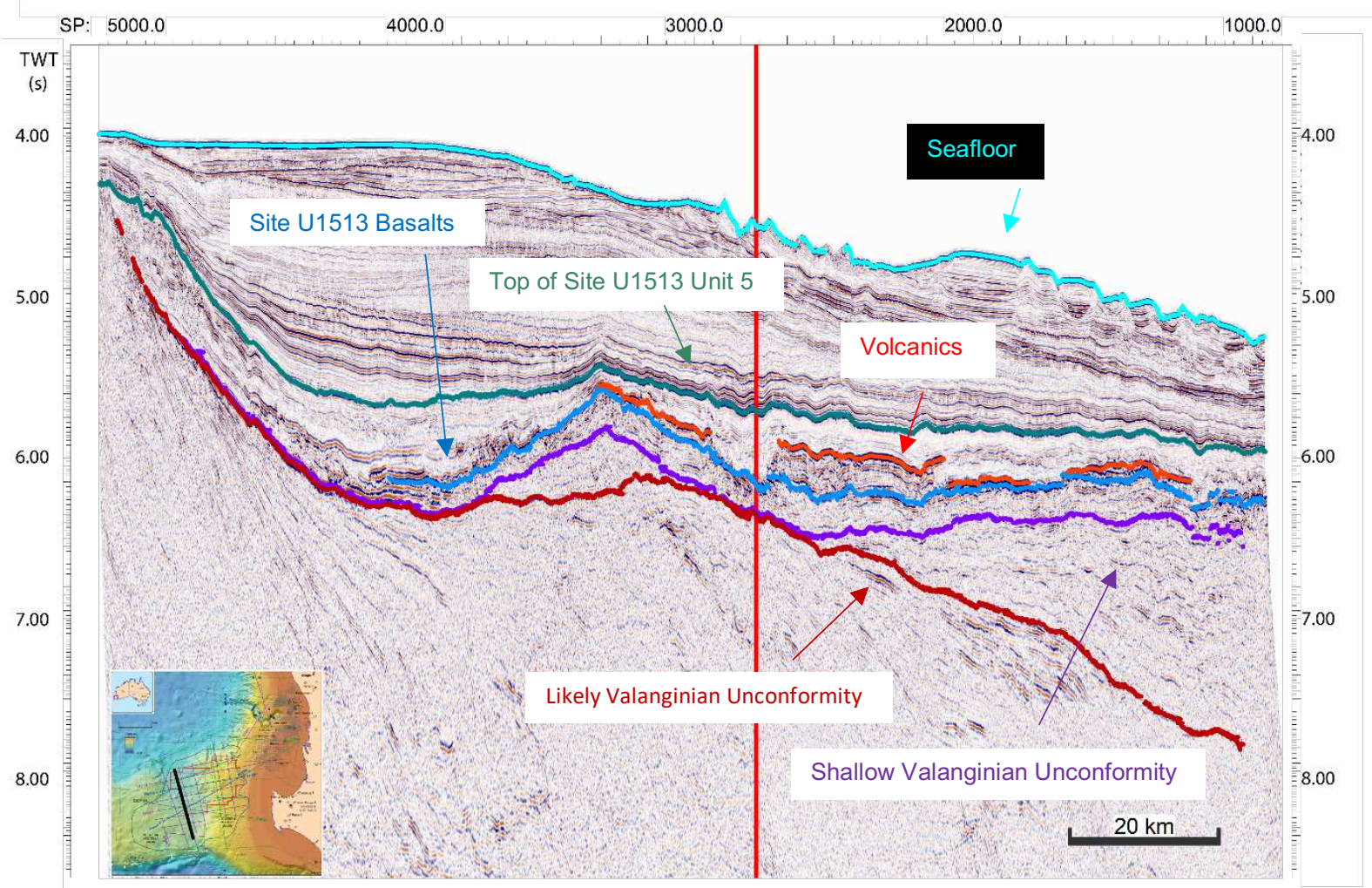

Figure 10. Seismic cross section in the time domain through the Mentelle Basin on line S310 17. The red vertical line indicates the intersection with line S310_07, shown in Fig. 9. From top to bottom: seafloor (turquoise), top of volcaniclastic Unit 5 (dark green), volcanic features (orange), basalts encountered at U1513D (blue), shallow Valanginian Unconformity possibility (purple), likely Valanginian Unconformity (maroon). Y-axis is in two-way travel time (s). Mapped faults are not pictured here for image clarity. Locator map in bottom left modified from Borissova et al., 2010.

\section{Stratigraphic Intervals of Interest}

\section{Top of volcaniclastic Unit 5}

The youngest horizon mapped in this is study is the top of the volcaniclastic sequence and its laterally equivalent strata, which corresponds with Lithostratigraphic Unit 5 encountered at IODP Site U1513. Our primary control for this surface is IODP 369 Site U1513D, where the top of Unit 5 was encountered in the borehole (Fig. 11). The surface corresponds with the lower Aptian age (126 Ma), when rifting on this part of the southwest Australian margin ended and seafloor spreading began between India and Australia (Lee et al., 2020). At Site U1513, Unit 5 is 
comprised of basalt clasts interbedded with siliciclastics (Huber et al., 2019b; Lee et al., 2020). In the seismic data, the top of Unit 5 and its laterally equivalent strata appear as an even, continuous, high amplitude reflector above a package of subparallel, less continuous, and lower amplitude reflectors. The reflector can be mapped throughout the $\mathrm{MB}$, but it is still unclear if it overlays volcaniclastic strata everywhere, as there is a lateral change in reflector character underneath the top of Unit 5 moving eastward throughout the basin.

\section{Top of basalt pile encountered at Site U1513}

The next surface mapped in this study is the reflector encountered at the top of the basalt pile (Unit 6) in IODP Borehole U1513D on the western edge of the MB (Fig. 11). While this reflector was initially believed to be the top of the basalt stratigraphic interval, mapping shows that this reflector interfingers with what we interpret to be younger basalt flows deeper in the MB. The surface we mapped appears as a high amplitude reflector with a semi-sub continuous character that occasionally grades laterally to a wavy or hummocky character.

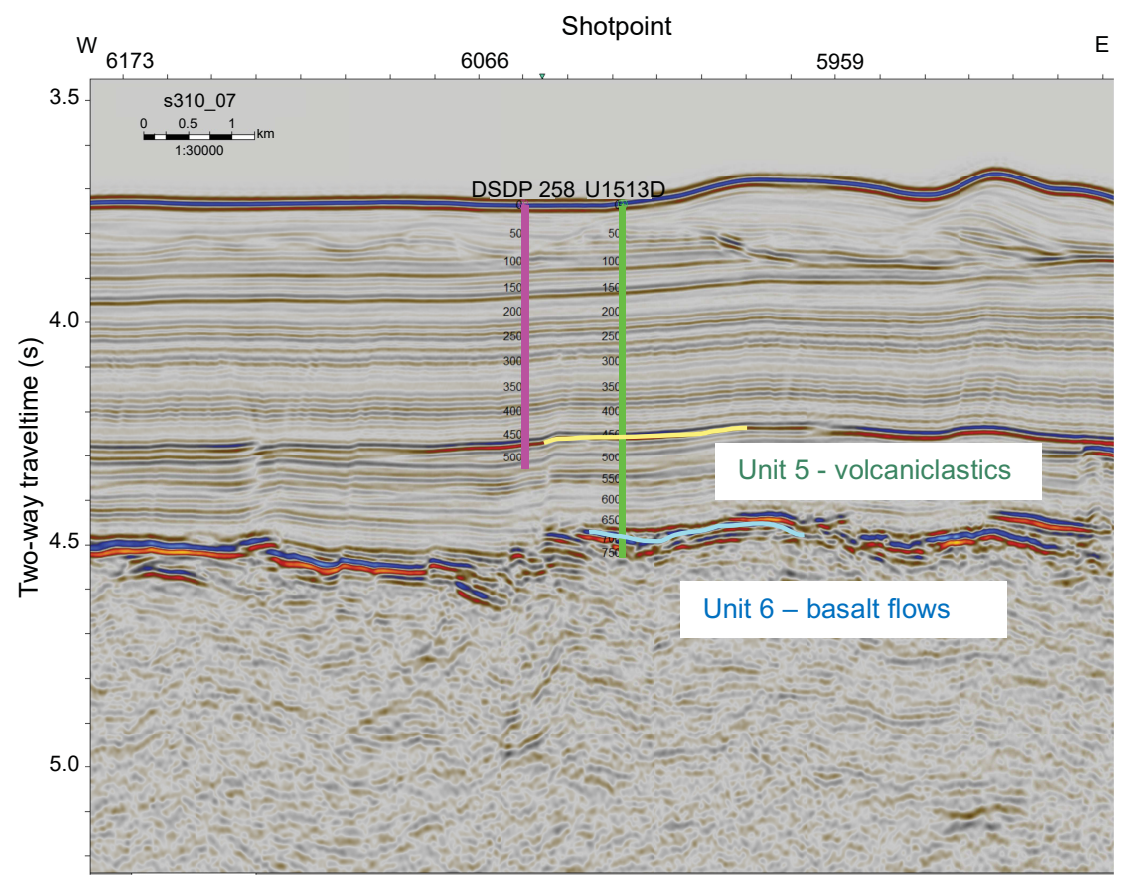

Figure 11. U1513D borehole tie modified from Huber et al., 2019. The top of volcaniclastic Unit 5 is shown in yellow, while the top of the basalts is in light blue. 


\section{Valanginian Unconformity}

The oldest horizon mapped in this study is the Valanginian Unconformity. It lies underneath the basalt pile encountered at site U1513D and corresponds with breakup and onset of seafloor spreading on the PAP further north (133 - 132 Ma) (Harry et al., 2020; Hall et al., 2013; Borissova et al., 2010). The unconformity surface has only been drilled in the MB at site U1515A, in the eastern part of the basin on the western flank of the Yallingup Shelf (Fig. 12). Maps shown here with that horizon are based on that one well tie and on seismic correlation to the Sugarloaf-1 borehole in the Vlaming Sub-basin (Fig. 13). On the eastern flank of the MB, the unconformity reflector is identifiable as a continuous angular unconformity and of higher amplitude than the discontinuous to chaotic reflectors underneath (Fig. 12). However, deeper in the basin, the unconformity becomes a disconformity, and in some areas a conformable stratigraphic surface, making it difficult to map with certainty (Fig. 14). In the areas where the unconformity is difficult to map, the reflector devolves into a wavy, sometimes chaotic low amplitude reflector that is parallel to and of similar amplitude and character to the surrounding reflectors for long portions of the seismic line. This led to uncertainty in the position of the Valanginian Unconformity in the deep basin, which was captured by mapping two possibilities "shallow" and "deep" alternatives for the horizon (Figs 9, 10, 14). 


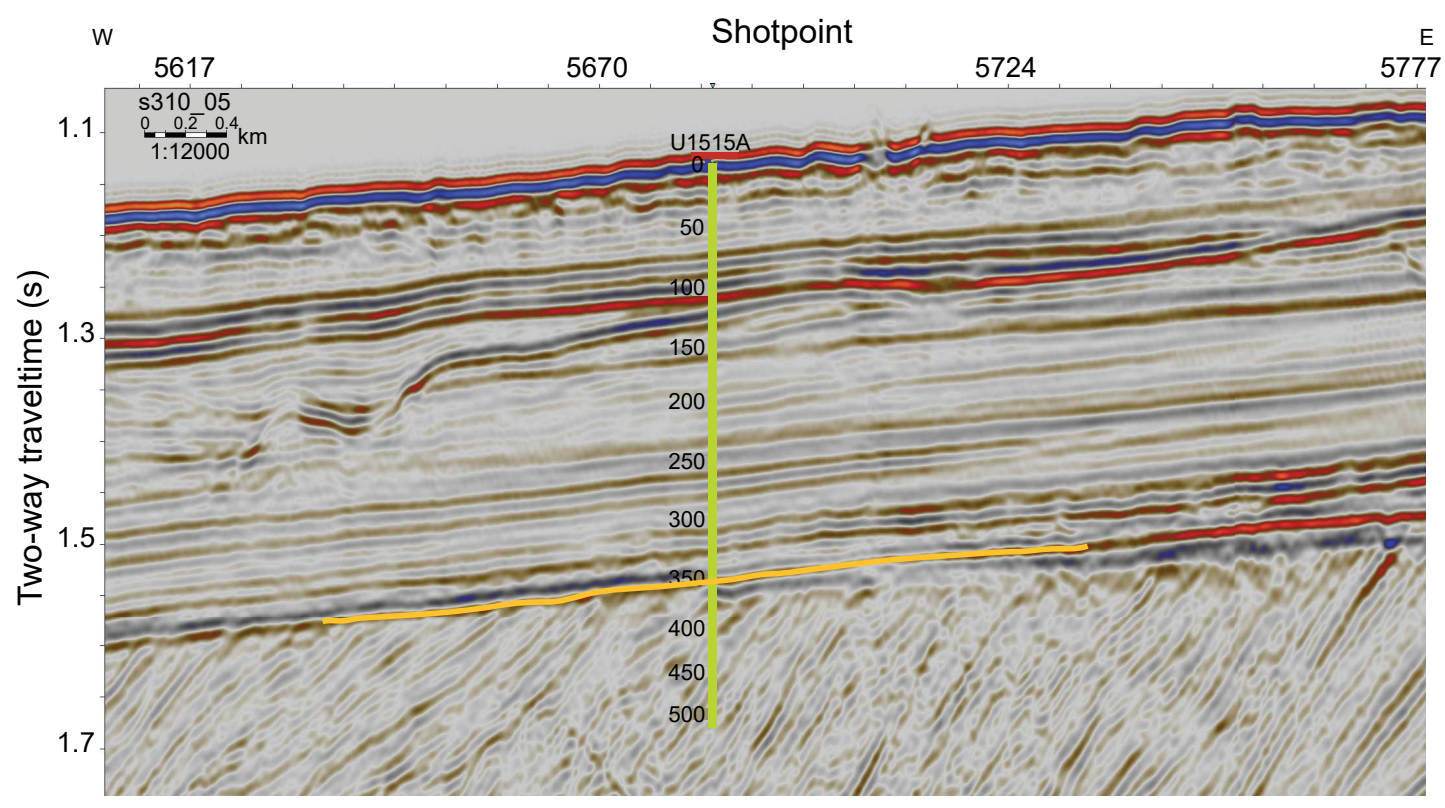

Figure 12. U1515A well tie modified from Huber et al., 2019. The Valanginian Unconformity surface is shown in orange. There is only one unconformity surface mapped at this location because the uncertainty occurs further west deeper in the Mentelle Basin, resulting in multiple unconformity possibilities. See Fig. 15 for borehole location.

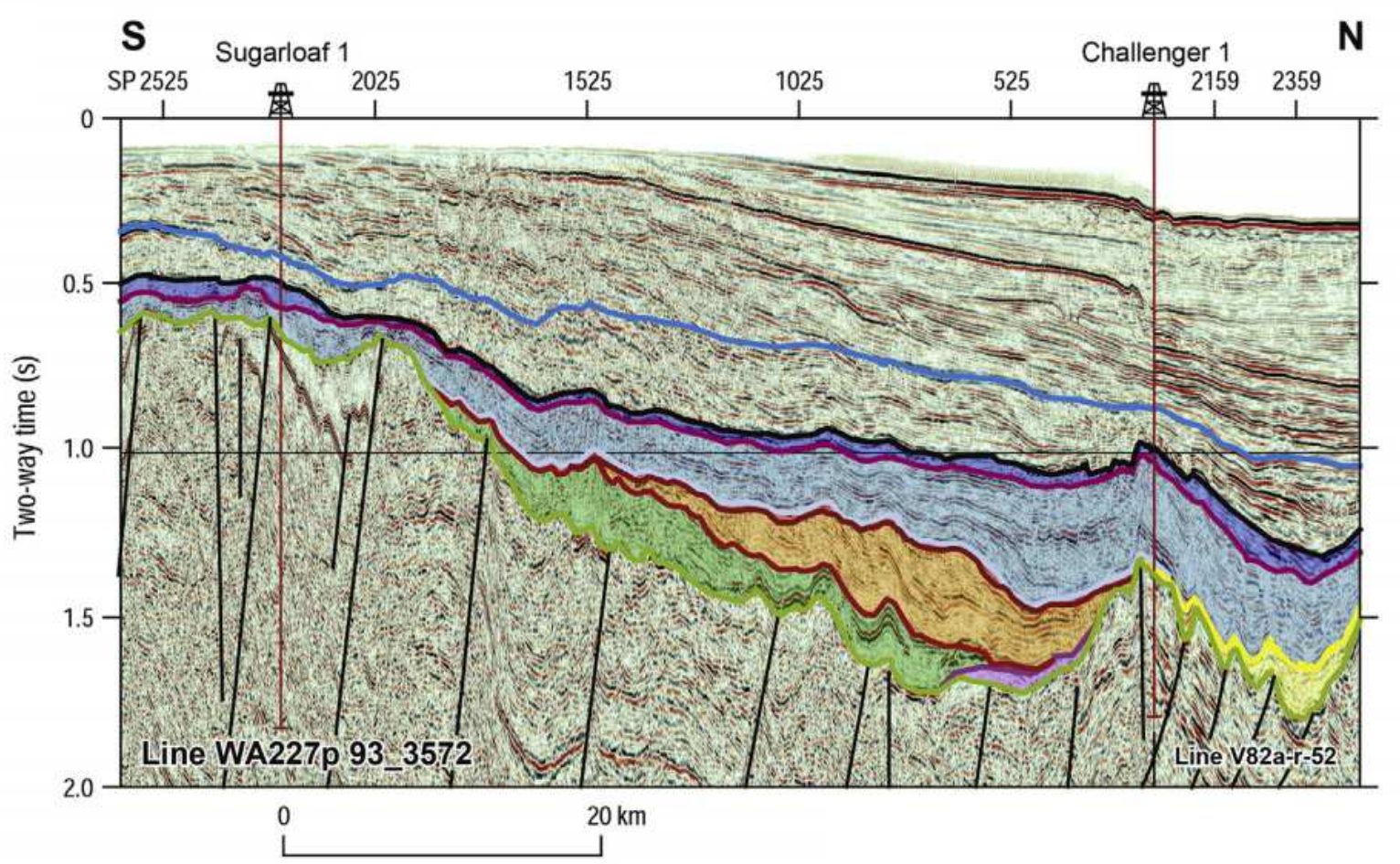

Figure 13. Valanginian Unconformity (green) well tie at Sugarloaf-1 in the southern Perth Basin modified from Lech et al., 2016. This seismic line is in the Vlaming Sub-basin, east of the Mentelle Basin and Yallingup Shelf. See Fig 15. For borehole location 


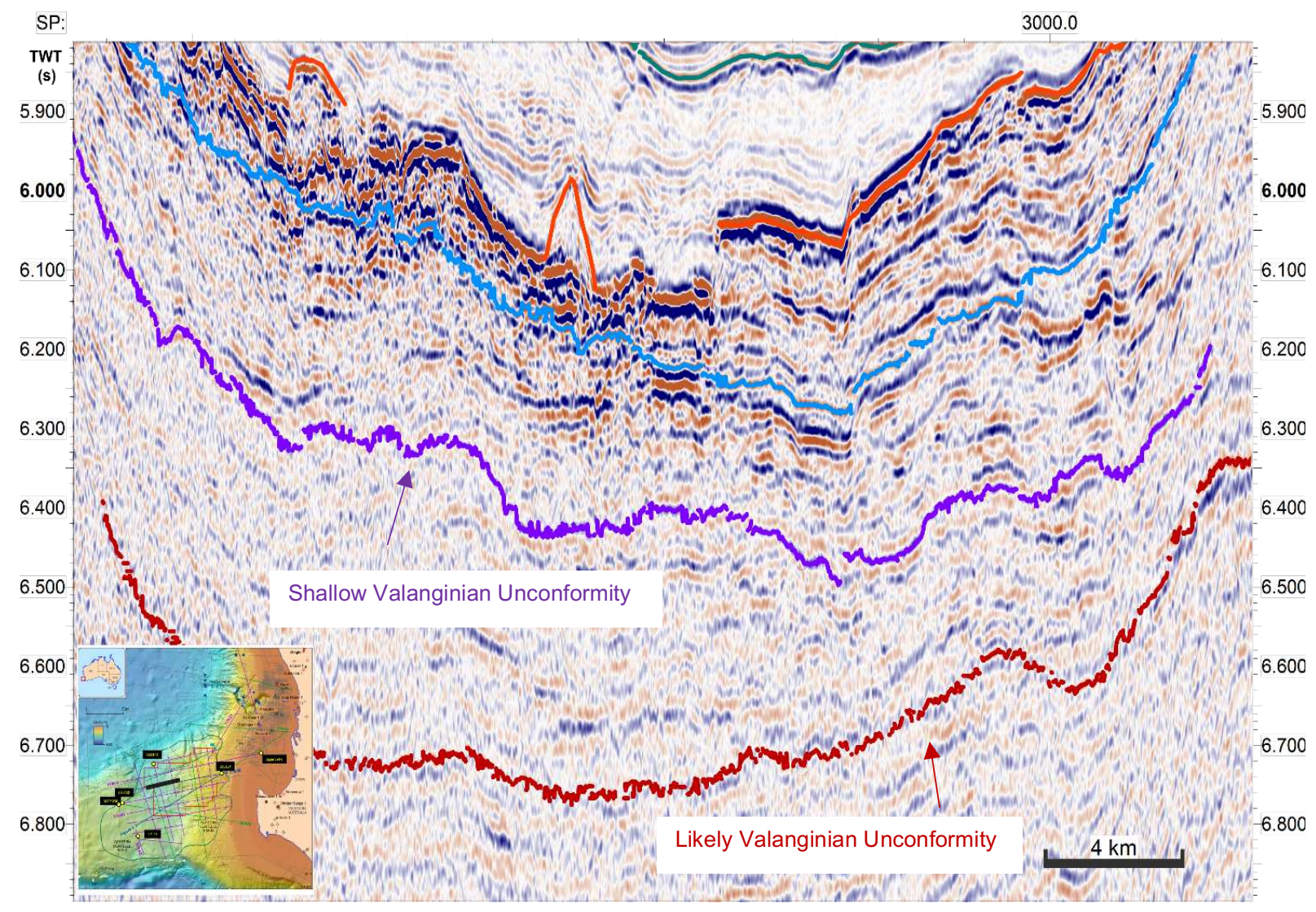

Figure 14. Valanginian Unconformity possibilities mapped in the MB. The unconformity possibilities pictured here on line S310_05 appear as conformable surfaces here in the deeper basin. Locator map modified from Borissova et al., 2010.

\section{Seismic Data}

Two sets of 2D seismic reflection data shot by Geoscience Australia were used. The oldest survey used was Survey GA 280 (S280), which was acquired in 2004. S280 consists of 7 lines that total 1060 line-km of $12 \mathrm{~s}$ record seismic data. The data has a $4 \mathrm{~ms}$ sample rate with an unknown fold and a $12 \mathrm{~m}$ CMP interval. The other seismic survey used was survey S310, which was shot in 2008 and 2009. It consisted of 16 seismic lines of $12 \mathrm{~s}$ record, 2 ms sample rate, and 106 fold seismic data. This survey added 2570 line-km to the seismic coverage, and reduced the grid spacing to $10-20 \mathrm{~km}$. Using a rough mean velocity of $3 \mathrm{~km} / \mathrm{s}$ (taken to be a representative average of the crystalline bedrock and sedimentary basin fill), the typical depth of 
penetration of the seismic data is about $18 \mathrm{~km}$. The dominant frequency was measured to be 46 $\mathrm{Hz}$ and $40 \mathrm{~Hz}$ in the post-rift and syn-rift stratigraphy, respectively. These dominant frequencies and mean velocity indicate seismic wavelengths of 75 and $65 \mathrm{~m}$ and a tuning thickness (resolution, taken to be one fourth of the wavelength) of $16.3 \mathrm{~m}$ in the post-rift stratigraphy and $18.8 \mathrm{~m}$ in the deeper syn-rift stratigraphy.

\section{Borehole Data}

Well data in our study area is limited to a deep exploratory well in the Vlaming Sub-basin to the east, two Deep Sea Drilling Project (DSDP) sites on the Naturaliste Plateau (Sites 258 and 264), and four boreholes from Integrated Ocean Drilling Program (IODP) Expedition 369 (Fig. 15). DSDP Site 264 did not penetrate syn-rift strata in the MB and is not discussed here.

\section{Sugarloaf-1}

The Sugarloaf-1 well is situated in the Vlaming Sub-basin in the southern half of the Perth Basin approximately $50 \mathrm{~km}$ west of the Australian coast and $72 \mathrm{~km}$ northwest of Bunbury (Crostella and Backhouse, 2000) (Fig. 15). It was drilled in 1971 by West Australian Petroleum Pty Ltd to a depth of $3660 \mathrm{~m}$. The borehole penetrated the Valanginian Unconformity at $875 \mathrm{~m}$ (Fig. 13), and then is mostly dominated by the Ottowiri mudstone member of the Yarragadee Formation (Nicholson et al., 2008). This well is used to tie the interpreted Valanginian Unconformity in the MB with the known unconformity in the Vlaming Sub-basin.

\section{DSDP 258}

The Site 258 borehole was drilled by the Deep Sea Drilling Project on the northern flank of the NP between October $25^{\text {th }}-29^{\text {th }}, 1972$ (Davies et al., 1974) (Fig. 15). The water depth is $2793 \mathrm{~m}$ at the borehole location, and it was drilled to a depth of $525 \mathrm{~m}$. Unit I in the borehole was 
coccolith ooze down to $114 \mathrm{~m}$ with shallow-water foraminifera present and was deposited starting in the late Miocene to present-day. Unit Ila is $89 \mathrm{~m}$ of yellowish gray - light gray interbedded chalk and siliceous limestone, and Unit IIb is $60 \mathrm{~m}$ of greenish gray coccolith chalk. These units range from Cenomanian to Santonian in age. Unit III is $22 \mathrm{~m}$ of dark greenish gray transitional clay and chalk, followed by $229 \mathrm{~m}$ of brownish/olive black detrital ferruginous clay (Unit IV) that is middle to late Albian in age. Unit $\mathrm{V}$ in the borehole is comprised of $11 \mathrm{~m}$ of Lower Cretaceous (undefined range) olive gray and greenish gray glauconitic sandstone and brown silty mudstone with deep-water foraminifera, indicating a transition between shelf and deepwater sedimentation. The sediments in the borehole generally coarsen downwards, suggesting a shallower depositional environment before subsiding to greater depths. Unit $\mathrm{V}$ at DSDP Site 258 correlates with the volcaniclastic Unit V encountered at IODP Site U1513 that is discussed below and is mapped in this study.

\section{IODP Expedition 369 Sites:}

The borehole descriptions below are all sourced from Huber et al., 2019a-e. Borehole locations are shown in Figure 15. Correlations between boreholes are shown in Figure 16 and are as described in IODP Volume 369.

\section{U1513}

There were five boreholes drilled at this location, with an approximate water depth of $2800 \mathrm{~m}$. Site $\mathrm{U} 1513$ is the westernmost borehole location in the MB, located on its western flank (Fig. 15). Four of the five holes drilled at this site were drilled between October $19^{\text {th }}-25^{\text {th }}, 2017$, while the last hole (U1513E) was drilled November $20^{\text {th }}-25^{\text {th }}, 2017$. This study concentrated on Hole U1513D, which penetrated $757.4 \mathrm{~m}$ below the sea floor, and was the only borehole to penetrate the basalts in the MB. At site U1513, Unit I is composed of $64.93 \mathrm{~m}$ of Pleistocene to late Miocene age calcareous ooze and nannofossil ooze with sponge spicules, which correlates with 
the late Miocene ooze at DSDP 258. Unit II is a $182.93 \mathrm{~m}$ thick Campanian to Cenomanian calcareous ooze and chalk, nannofossil ooze and chalk, claystone, and silicified limestone, which correlates to the Unit Ila and IIb chalks at DSDP 258 and indicates a deepwater depositional environment. Unit III is a 21.87 m thick Cenomanian alternation of green, light gray, and black nannofossil-rich claystone, correlating to the Unit III transitional claystone at DSDP 258. Unit IV is a $187.12 \mathrm{~m}$ thick interval comprised of Cenomanian to Albian black claystone and nannofossil-rich claystone, correlated to the Unit IV Albian black claystone at DSDP 258 and corresponding with a deepwater depositional environment. Unit $\mathrm{V}$ is a gray to black volcanic-rich sandstone $234.25 \mathrm{~m}$ thick, aged to Aptian and Valanginian time (126 - $134 \mathrm{Ma})$ and interbedded with thin siltstone beds, indicating above sea level to shelf depths deposition. This correlates with Unit V at DSDP Site 258 (Lee et al., 2020). Unit VI is an $82.20 \mathrm{~m}$ thick volcanic sequence of unknown age composed of basalts, breccia, and dolerite dikes, and the vesicular texture with brown to red oxidation indicate emplacement in a subaerial to shallow water environment (Huber et al., 2019b; Tejada et al., 2020).

\section{U1514}

Drilled November $5^{\text {th }}, 2017$ by IODP Expedition 369, U1514C is the northernmost borehole in the $M B$, and was the drill site in the deepest water at a depth of 3850 m (Huber et al., 2019) (Fig. 15). It lies on the north-northwest south-southeast trending seismic line S310_17 and was drilled to a sub-seafloor depth of $516.8 \mathrm{~m}$. Unit I consists of $81.2 \mathrm{~m}$ of Pleistocene to Eocene pale brown to pale yellow nannofossil ooze, foraminiferal ooze, sponge spicule-rich nannofossil ooze, and biosiliceous ooze. Unit II is $308 \mathrm{~m}$ of nannofossil chalk, nannofossil-rich claystone, and claystone, indicating a deepwater depositional environment. Unit III is comprised of an at least 126 m thick sequence of greenish gray/brown/black claystone and nannofossil-rich claystone with low to medium bioturbation, also indicative of a deepwater marine environment. 
The bottom of this unit was not penetrated, so U1514 did not penetrate the strata targeted in this study.

U1515

This well was drilled November $10^{\text {th }}, 2017$, and is the easternmost borehole drilled in the Mentelle Basin (Fig. 15). It lies on the eastern flank of the basin on a west to east-striking seismic line S310_05 at a water depth of $\sim 850 \mathrm{~m}$ and penetrated to a depth of $517 \mathrm{~m}$ below the seafloor. Unit I is $129 \mathrm{~m}$ of Pleistocene to upper Campanian or upper Santonian light greenishgray calcareous ooze with sponge spicules, that grades down to chert, calcareous chalk, and sandy limestone. Unit lla consists of a massive, black to greenish black glauconitic silty sandstone with an unknown age about $116 \mathrm{~m}$ thick, indicative of a continental shelf depositional environment. Unit IIb is about $41 \mathrm{~m}$ thick of dark gray silty sandstone with black claystone suggesting an outer neritic to bathyal depositional environment, and the interval between 334.89 - 345.21 mbsf has been dated to be Valanginian (139 Ma) or younger in age (Wainman et al., 2019). The interval of Ilb between $354.40-375.52 \mathrm{mbsf}$ is dated to the Early Cretaceous (Wainman et al., 2019). Unit Ilc is a $\sim 111 \mathrm{~m}$ thick gray to dark gray pre-rift silty sandstone and black claystone that also contains plant debris, is dated between the Middle - Late Jurassic period, and was deposited in an fluvio-lacustrine environment (Wainman et al., 2019). The Valanginian Unconformity is interpreted to be between 345.21 and 354.40 mbsf at Site U1515 (Wainman et al., 2019). Units Ilb and Ilc thus bracket the marine transgression above the Valanginian Unconformity.

U1516

Four boreholes were drilled at this site between November $14^{\text {th }}-18^{\text {th }}, 2017$ in a water depth of approximately $2675 \mathrm{~m}$. The drilling location lays along the north-northwest south-southeast striking seismic line S310_67, located in the southwest corner of the western flank of the MB. 
The two deepest boreholes were U1516C and U1516D, drilled to depths of 541.6 and $477.6 \mathrm{~m}$ respectively. Depths for the following stratigraphic description were not provided, as the observations were made by stitching the two boreholes together. Unit la is a $257.86 \mathrm{~m}$ thick Pleistocene to Paleocene massive, structureless white to light greenish gray calcareous/nannofossil ooze with sponge spicules. Unit lb is a $158.94 \mathrm{~m}$ thick Miocene to Eocene calcareous/nannofossil chalk with sponge spicules that is also mottled, massive, and structureless, indicating a deepwater marine depositional environment. Unit Ic is a $14.76 \mathrm{~m}$ thick Paleocene nannofossil-rich claystone and claystone with intense bioturbation, which indicates a deepwater depositional environment. Unit II is a 38.29 m thick Turonian nannofossil chalk with clay, while Unit III is a 7.86 m thick Cenomanian claystone with some nannofossils and clayey nannofossil chalk, indicative of a deepwater marine environment. Unit IV is a $60.9 \mathrm{~m}$ thick Cenomanian to Albian black and dark greenish gray nannofossil-rich claystone and claystone with nannofossils, still inferring a deepwater depositional environment. Unit IV at Site U1516 is inferred to be equivalent to post-rift Unit IV at Site U1513. U1516 did not penetrate into the volcaniclastic or pre-rift strata. 


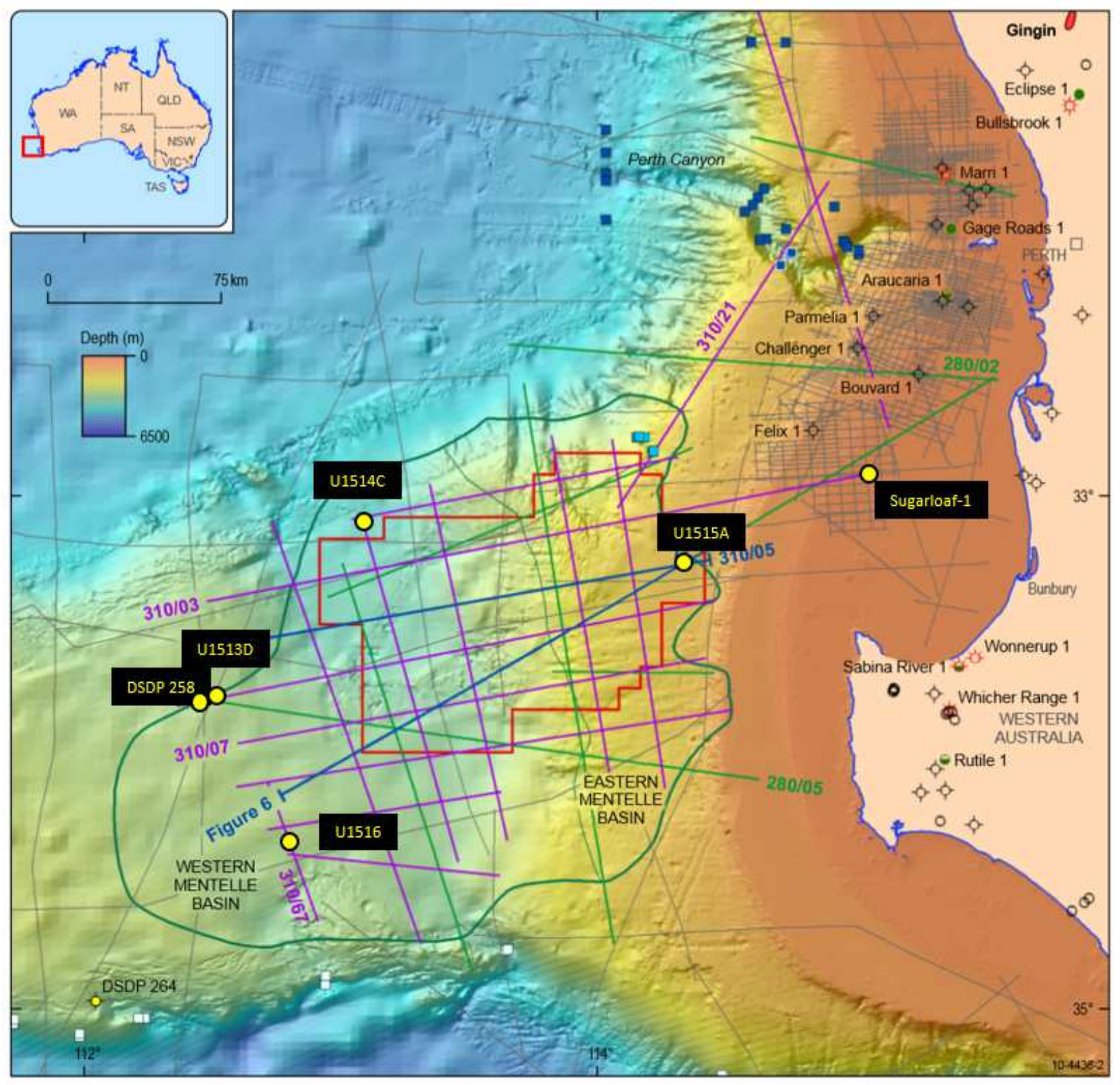

Figure 15. Locations of boreholes used in this study. Modified from Borissova et al., 2010. 


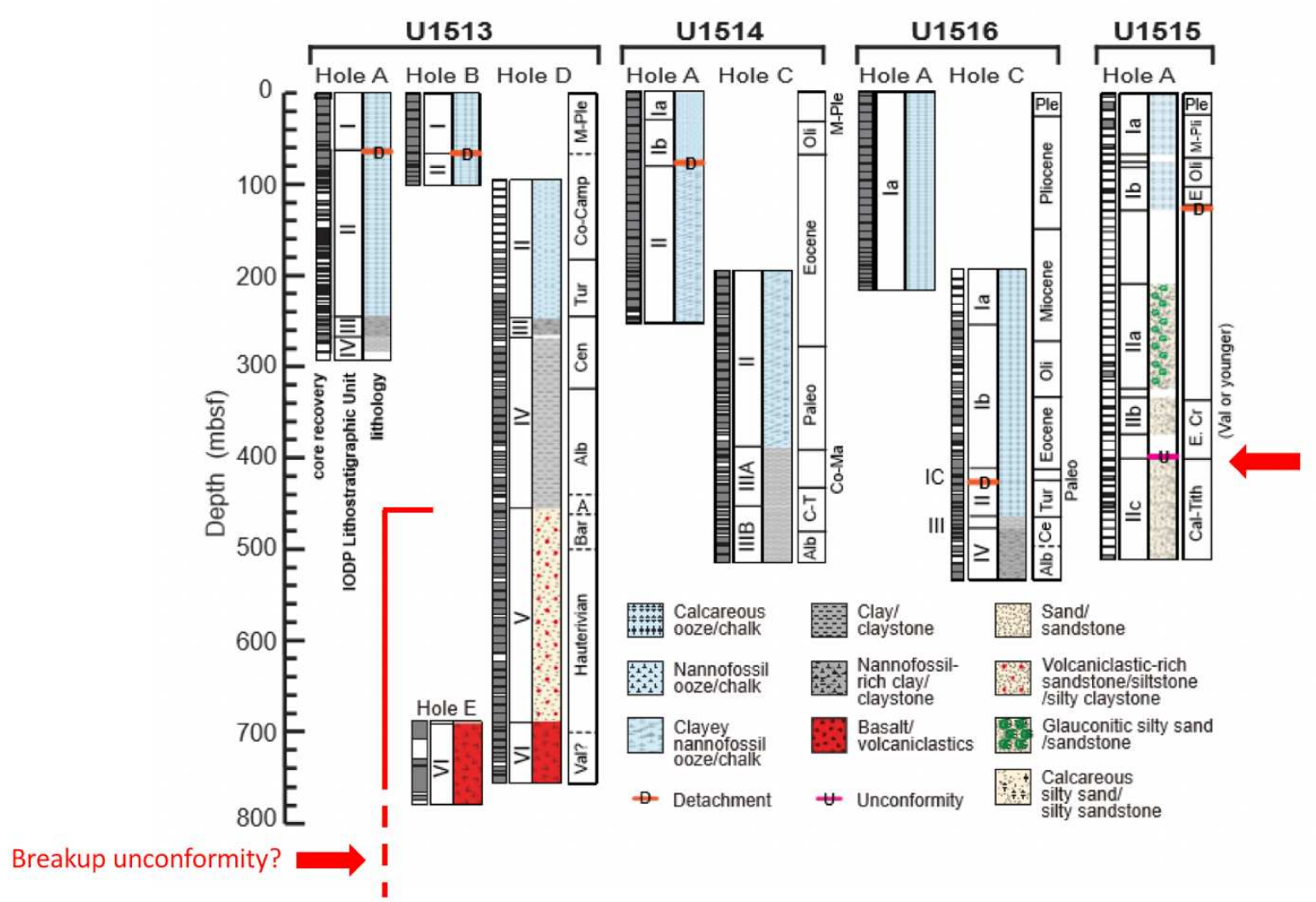

Figure 16. Stratigraphic columns for IODP Expedition 369 borehole sites, modified from Harry et al., 2020. The red arrows denote the Valanginian Unconformity, which was encountered in U1515A but not penetrated elsewhere in the Mentelle Basin. The solid red to dashed bracket indicate our interval of interest, which is from the Valanginian (139 Ma) to the start of the Aptian (126 Ma) age.

\section{Correlation and Mapping Methods}

\section{Seismic Correlation}

IHS Kingdom Software (2018) was used to map horizons and generate time and depth structure maps and time and depth isochore maps. Seismic horizons were correlated across each 2D seismic profile and were verified by time-tying loops around each of the seismic line intersections. Where available, seismic correlations were verified by comparing to borehole data. Sugarloaf-1 in the Vlaming Sub-basin and site U1515A in the eastern MB were used to tie the Valanginian Unconformity, and site U1513D on the western slope of the basin was used to tie the basalt horizon mapped. 


\section{Mapping Methods}

Kingdom Suite's proprietary flex gridding algorithm was used to generate time-structure maps and isochore maps for each horizon and interval between horizons. The algorithm computes a surface that passes through or close to (within a specified criteria) the travel time or isochore data measured from the seismic profiles. The surface is constrained to minimize a weighted blend of curvature and the Laplacian misfit between the computed surface and the constraining data, with successive grid refinements applied until a specified misfit criterion is achieved. Once the reflectors of interests were mapped in the time domain, interval velocities derived from common midpoint velocity analyses of seismic data from the MB were used to convert to depth. Velocity analyses were selected from five locations throughout the basin that were free of faults and intrusions (Fig. 17). Velocity analyses from five clustered common midpoint gathers from each of these five locations were piecewise averaged to create a stepwise profile displaying average interval velocity vs. travel time (Fig. 18). Steps in the velocity profiles were then correlated with each of the stratigraphic intervals of interest. The five summed velocity profiles showed little variation across the basin, so the mean interval velocities from each of the locations were then averaged within each interval to create a single basin-wide velocity profile. Isochore maps were then converted to depth by multiplying each stratigraphic interval with its corresponding interval velocity and dividing by two. Isochores were then summed to create a depth structure map to the seafloor and the likely Valanginian Unconformity. 


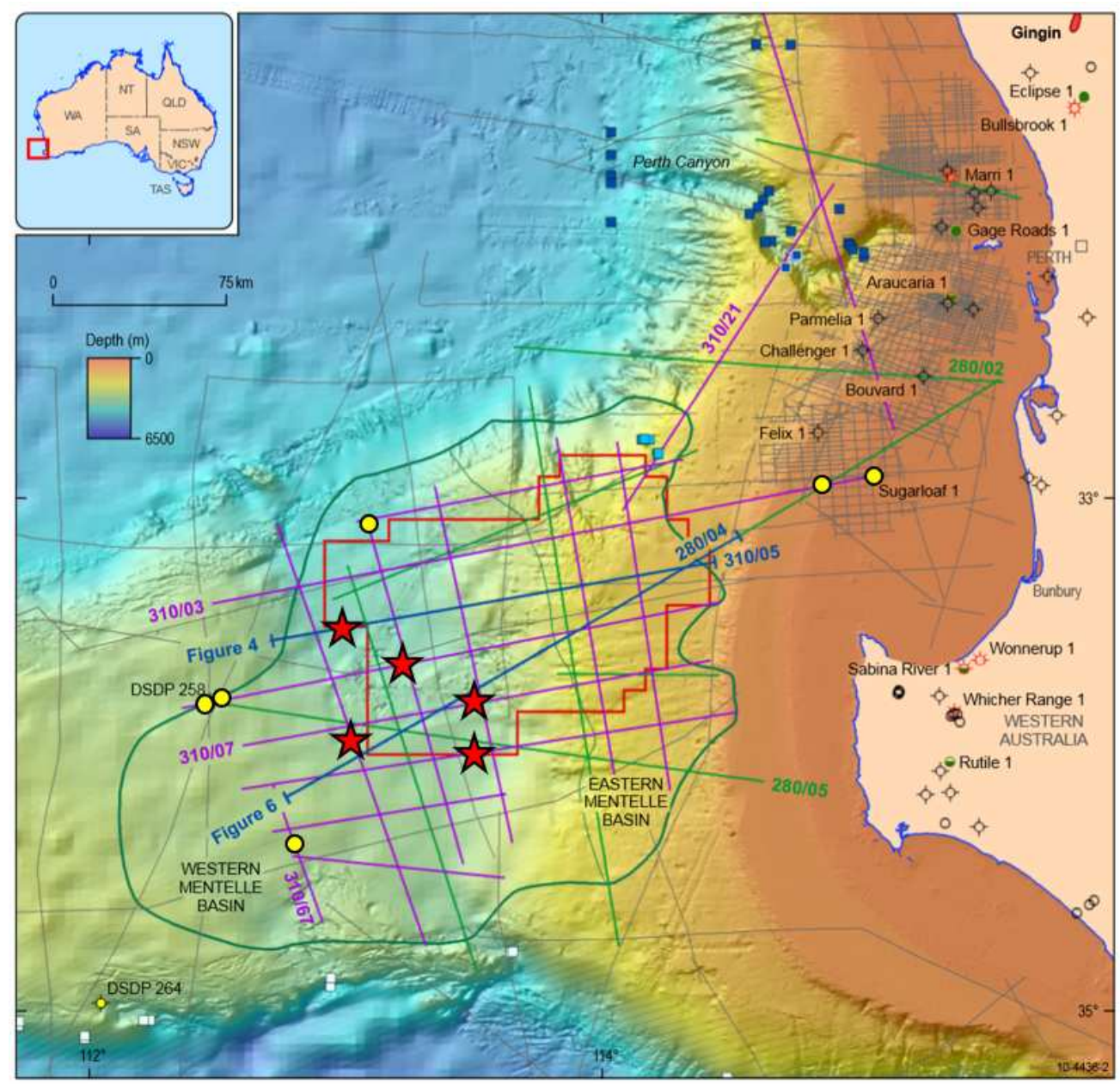

Figure 17. Basemap modified from Borissova et al., 2010 showing locations of velocity analyses (red stars). 
a)

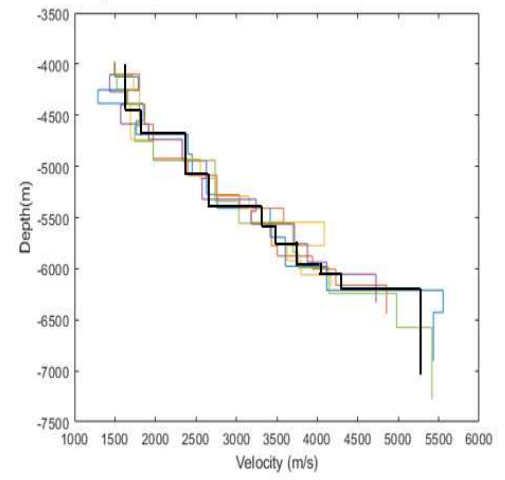

b)

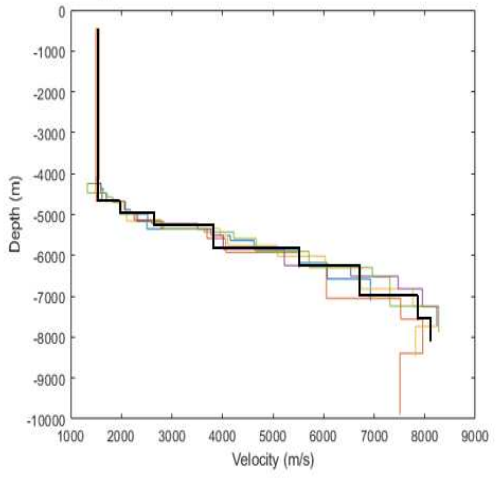

c)

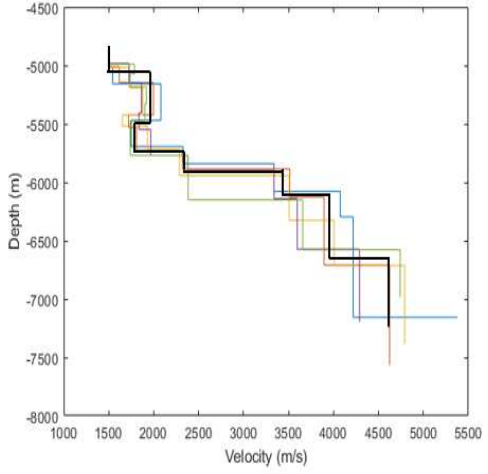

d)

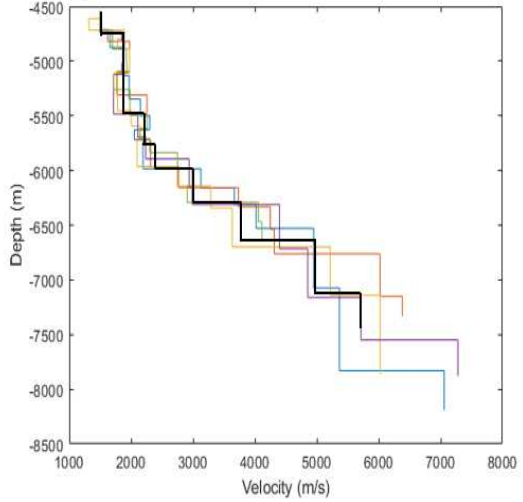

e)

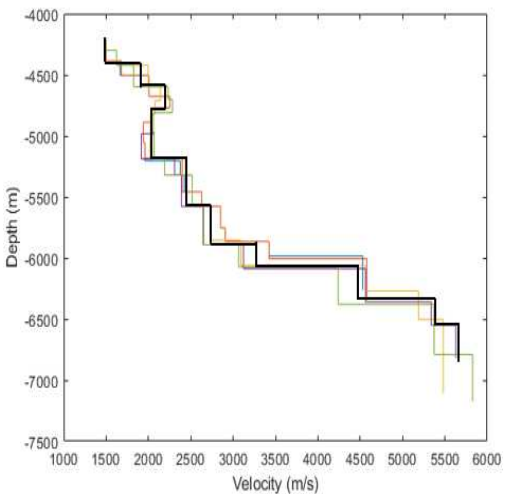

Figure 18. Stepwise interval velocity profiles throughout the Mentelle Basin. The black line on each plot indicates the average velocity picked for each interval. On each plot, depth $(\mathrm{m})$ is on the $y$-axis and velocity $(\mathrm{m} / \mathrm{s})$ is on the x-axis. (a) Velocity profile on line S310_10 around shotpoint 3500. (b) Velocity profile on line S310_18 around shotpoint 3460. (c) Velocity profile on line S310_05 around shotpoint 2300. (d) Velocity profile on line S310_07 around shotpoint 4000. (e) Velocity profile on line S310_09 around shotpoint 3020.

Table 1. Interval velocities and average interval velocities from five locations within the Mentelle Basin. An asterisk denotes that that value was ignored due to being anomalously high or low compared to the other velocities from that same interval in different locations.

\begin{tabular}{|c|c|c|c|c|c|c|}
\hline & $\begin{array}{c}\text { S310_18 } \\
\text { Velocities (m/s) }\end{array}$ & $\begin{array}{c}\text { S310_10 } \\
\text { Velocities (m/s) }\end{array}$ & $\begin{array}{c}\text { S310_09 } \\
\text { Velocities (m/s) }\end{array}$ & $\begin{array}{c}\text { S310_07 } \\
\text { Velocities (m/s) }\end{array}$ & $\begin{array}{c}\text { S310_05 } \\
\text { Velocities (m/s) }\end{array}$ & $\begin{array}{c}\text { Average } \\
\text { Interval } \\
\text { Velocity (m/s) }\end{array}$ \\
\hline $\begin{array}{c}\text { Interval 1: } \\
\text { Seafloor to Top } \\
\text { of Unit 5 }\end{array}$ & 1800 & 2200 & 2200 & 1800 & 2000 & 2000 \\
\hline $\begin{array}{c}\text { Interval 2: Top } \\
\text { of Unit 5 to Top } \\
\text { of Basalts at } \\
\text { U1513D }\end{array}$ & 2700 & $3300^{*}$ & 2700 & 2700 & 2500 & 2650 \\
\hline $\begin{array}{c}\text { Interval 3: Top } \\
\text { of Basalts to } \\
\text { Shallow } \\
\text { Valanginian } \\
\text { Unconformity }\end{array}$ & 3900 & 3700 & 3400 & 3800 & 3600 & 3680 \\
\hline $\begin{array}{c}\text { Interval 4: } \\
\text { Shallow } \\
\text { Valanginian } \\
\text { Unconformity } \\
\text { to Likely } \\
\text { Valanginian } \\
\text { Unconformity }\end{array}$ & 3900 & 4000 & 4500 & 3800 & & 4000 \\
\hline
\end{tabular}




\section{CHAPTER IV: RESULTS}

\section{Seismic Horizons and Facies}

\section{Seafloor}

The seafloor was very simple to map as a high amplitude, continuous reflector at the top of each seismic line throughout our data coverage. It appeared as a trough and a zero phase (symmetric) wavelet on the S310 data.

Syn-rift volcaniclastic strata and age equivalents (Site U1513 Unit 5)

The top of the volcaniclastic strata (Unit 5 at site U1513, 126 Ma) and its laterally equivalent strata appear as a continuous, high amplitude reflector above a package of lower amplitude, continuous to semi-continuous reflectors, which allowed for mapping with high certainty across the MB. However, as the reflector neared its termination along the eastern slope of the basin, the amplitude decreased but maintained its continuity as the seismostratigraphic unit onlaps onto the underlying basalts and older syn-rift strata. This seismostratigraphic unit extends westward from its pinchout on the eastern half of the basin (Fig. 9) to west of boreholes U1513D and DSDP 258, pinches out at the very southern extent of the MB (Fig. 10), and extends northwards towards the PAP (Fig. 10).

\section{Volcanic Features}

There are two main types of what are interpreted to be volcanic features (based on seismic character) within the MB. One feature style appeared as a high amplitude, continuous reflector 2 - $20 \mathrm{~km}$ wide, interpreted to be subaerial volcanic flows (this interpretation was confirmed at IODP Site U1513D, where these flows were drilled at one of these reflectors sequences). The seismic data shows that these flows are stratigraphically and spatially widespread in the lower 
half of the volcaniclastic unit and are common but more spatially restricted to the region around the basin axis in the upper half of the unit. They lie between the top of Unit 5 (Aptian) and the basalts (constrained to be $>132 \mathrm{Ma}$ ), so are between Aptian and at least late Valanginian in age (Harry et al., 2020).

The other type of volcanic feature commonly seen on the seismic profiles appears as smallerscale, $0.5-1.5 \mathrm{~km}$ wide cone-shaped surfaces with chaotic reflections underneath that crosscut mapped horizons. These are interpreted to be volcanic cones emplaced in a subaerial to subaqueous environment and are scattered throughout the MB from the western slope to the toe of the eastern slope. However, at the toe of the eastern slope in the northern end of the basin is a much larger cone-shaped feature $8-10 \mathrm{~km}$ wide. The volcanic cones in the deep MB vary in age, as some crosscut the top of Unit 5, while others crosscut the basalts horizon, signifying these features were emplaced over a period of time between the late Valanginian and post-Aptian.

\section{Top of basalts at U1513D}

High amplitude reflectors interpreted to be basalt flows within the volcaniclastic stratigraphic unit were correlated through the central MB to the eastern slope based on the borehole tie at U1513D. There are similar reflectors also interpreted to be basalt flows extending downward below this particular flow, but it is unclear where the transition to pre-rift basement or syn-rift strata occurs. This particular basalt flow at site U1513 was mapped eastward with confidence to a large offset $(0.4 \mathrm{~s})$ fault. However, east of the fault and in the MB, the reflector marking the top of the basalt pile encountered at U1513D interfingers with similar reflector sequences displaying a high amplitude semi-continuous character. Lee et al. (2020) interpreted the basalts to be restricted to the portion of the Naturaliste Plateau that lies west of this fault. Here, the basalt flows encountered at U1513D are interpreted to extend down the western slope of the MB and eastward to their termination along the eastern slope of the basin. I thus interpret the majority of 
the $\mathrm{MB}$ to be underlain by late syn-rift basalts of similar age to the Bunbury Basalt that is encountered in the southern Perth Basin. While the basalt reflector pinches out to the south in the basin (Fig. 10), there is no evidence of thinning or termination of the basalt reflector package toward the northern margin (Fig. 10). While the basalts reflector was mapped with high certainty on the western edge of the basin, the reflector changed character eastward from continuous and high amplitude to semi-continuous and of a lower amplitude. This is interpreted to indicate a transition from interfingered volcanic/volcaniclastic strata (as in Unit VI at Site U1513D) to clastic strata shed from the emergent Yallingup Shelf.

\section{Valanginian Unconformity}

Starting on the eastern slope of the MB, the unconformity surface was mapped from the borehole tie at U1515A, where it was clear to the eye and easy to correlate. The surface appeared as a high amplitude reflector with an angular unconformity configuration due to the reflection termination pattern, but that character changed deeper in the MB. On both the western and eastern slopes, the unconformity becomes more difficult to follow because reflectors above and below the surface bifurcate and diverge downdip into the basin. The unconformity also changes from an angular unconformity to a disconformity. In the deeper central and shallowing western regions of the basin, the reflection terminations against the unconformity are difficult to discern, resulting in high uncertainty when mapping. The reflector originally mapped changed as well to a sub-continuous to discontinuous lower-amplitude character. This uncertainty led to mapping two possibilities for the unconformity - a "shallowest" and a deeper "likely" horizon.

The shallowest unconformity option is the shallowest reflector below the high amplitude reflectors that are confidently identified as basalts. This option can be traced across the basin to the eastern flank, although it does not always appear to be capped by high amplitude reflectors interpreted to be basalts in the east. Starting from near the toe of the eastern slope of the MB, 
this surface spans west to borehole U1513D, and the full north to south coverage of the seismic data.

The deeper unconformity surface follows reflectors that separate downlapping volcanic strata from dipping strata on the east and west flanks. However, the reflectors become conformable in the middle of the basin (Fig. 14), and along with the seismic character changes create the uncertainty. Deeper reflectors than the one shown in Figs. 9 and 10 were followed, but near the basin axis these reflectors become indistinguishable from the divergent reflectors that form the deep crust. This is why the deeper unconformity mapped becomes the "likely" unconformity option. This likely surface covers the same region as the "shallow" possibility, but also ranges eastward past site U1515 onto the Yallingup Shelf and into the Vlaming Sub-basin. Eastward of site U1515 and to the borehole tie at Sugarloaf-1 in the southern Perth Basin, the unconformity is obvious and simple to map.

\section{Structure Maps}

The time structure maps show the MB as a structural low, flanked to the east by a steeper slope and a gentler one to the west. The basin shallows to the south and plunges to the north towards the Perth Abyssal Plain. Refer to Figs. 9 and 10 to see seismic cross sections of the basin structure west to east and north to south, respectively. The seafloor map shows a bathymetric trough plunging to the NNW and is bordered by the Yallingup Shelf to the east and the NP on the west (Fig. 19). The map of the volcaniclastics and age-equivalent strata (Fig. 20) display the MB with a steeper east slope than west slope, and that the basin shallows to the south and plunges to the north. There is slightly sharper relief on the basalt horizon (Fig. 21), which displays a narrower basin trough than the deeper Valanginian Unconformity horizons (Figs. 22, 23). 


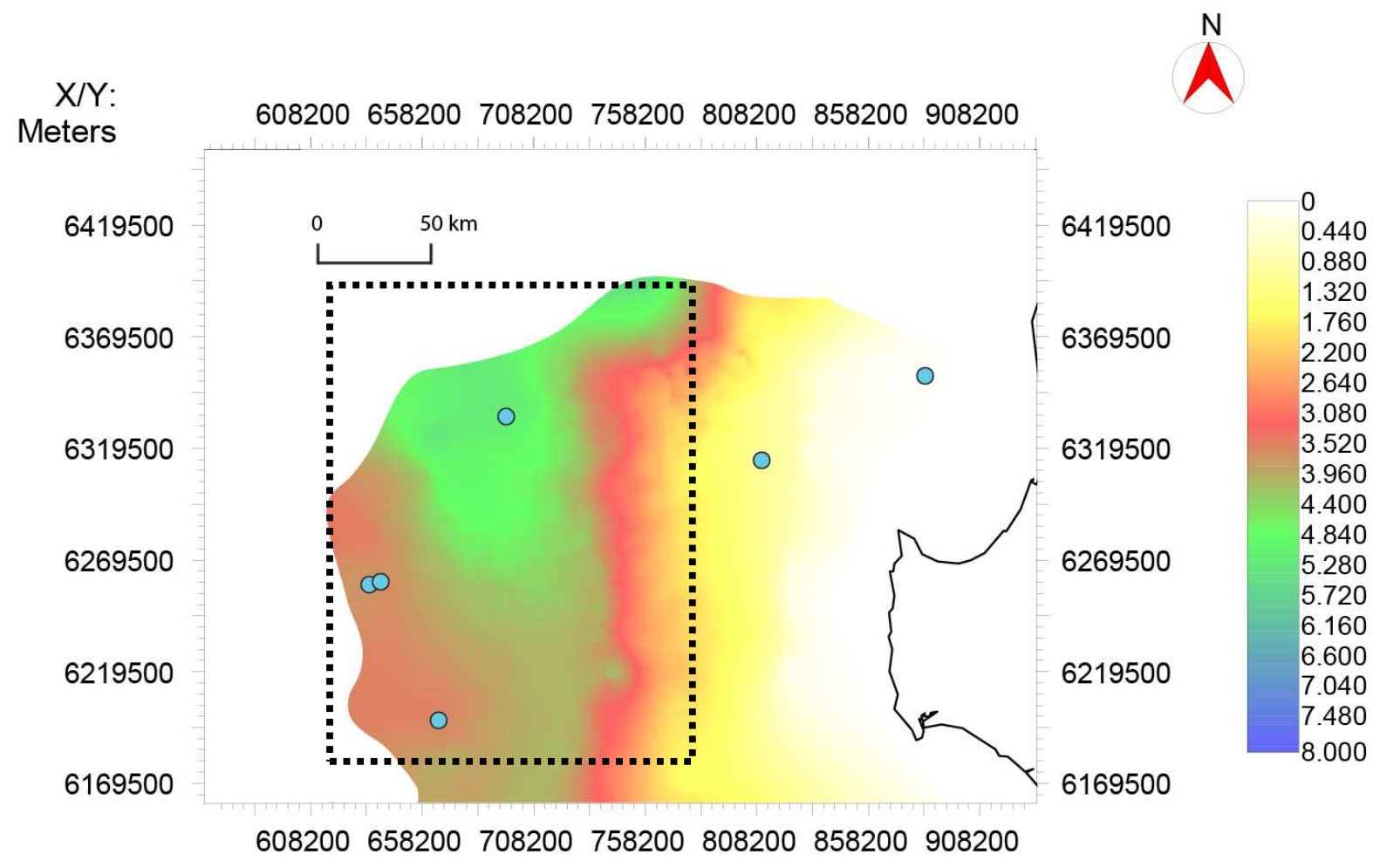

Figure 19. Seafloor time structure map. Eight seconds of relief are shown. Seafloor follows a similar geometry to the Mentelle Basin, with the greatest water depth above the northern basin axis and shallowing eastward up the Yallingup Shelf. Australian coastline is in black to the east. Black dashed box outlines area shown in Figs. $20-30$. Borehole locations are indicated by the blue circles, clockwise starting from the southwest: U1516, DSDP 258, U1513D, U1514C, U1515A, Sugarloaf-1. 


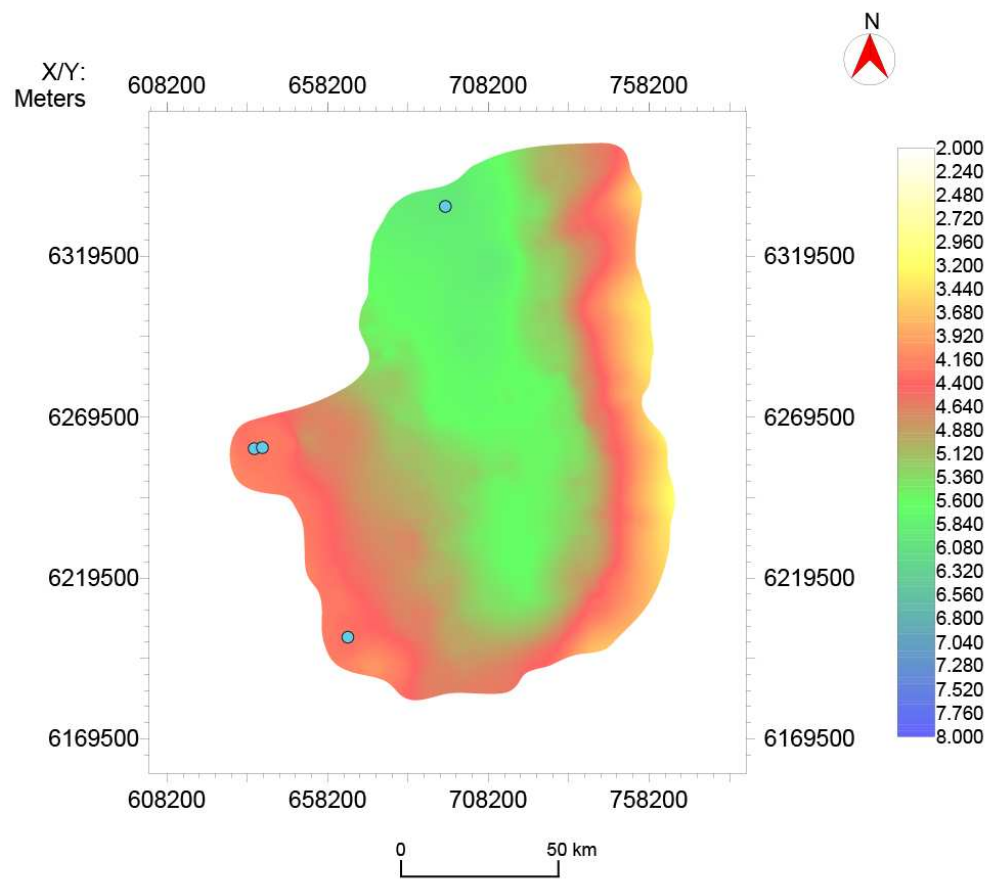

Figure 20. Top of Unit 5 at Site U1513 (volcaniclastics and age-equivalent strata) time structure map. Three seconds of relief are shown. Unit 5 terminates on the eastern slope of the basin, shallows to the south, and plunges to the north. The eastern slope is steeper than the western slope, and the basin axis strikes NNW-SSE around the geographic center of the basin. The blue circles denote borehole locations. Starting from the south and moving clockwise: Hole U1516, DSDP 258, Hole U1513D, Hole U1514C.

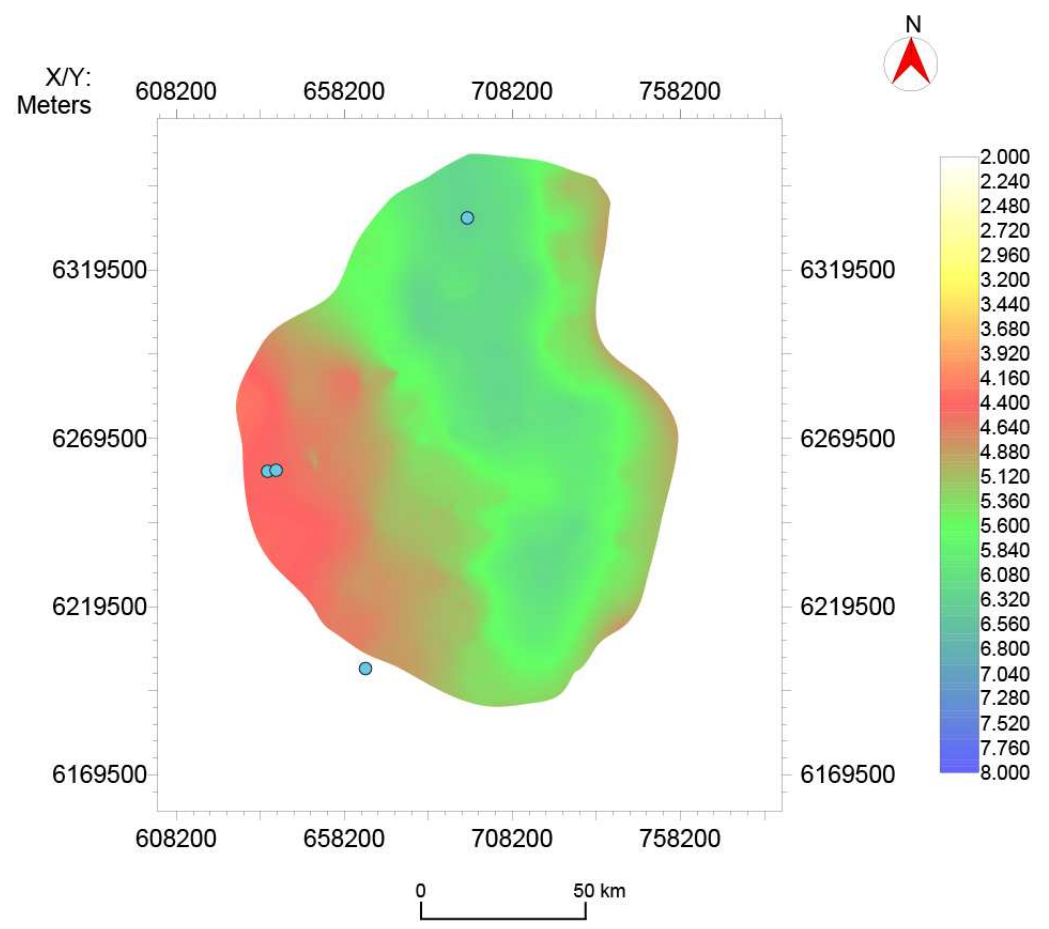

Figure 21. Site U1513 basalts time structure map. Relief is about $2.7 \mathrm{~s}$. The basalts cover the western region of the Mentelle Basin before terminating at the toe of the eastern slope. The horizon pinches out on the southern tip of the basin but plunges northwards. The blue circles denote the borehole locations, see Fig. 17. 


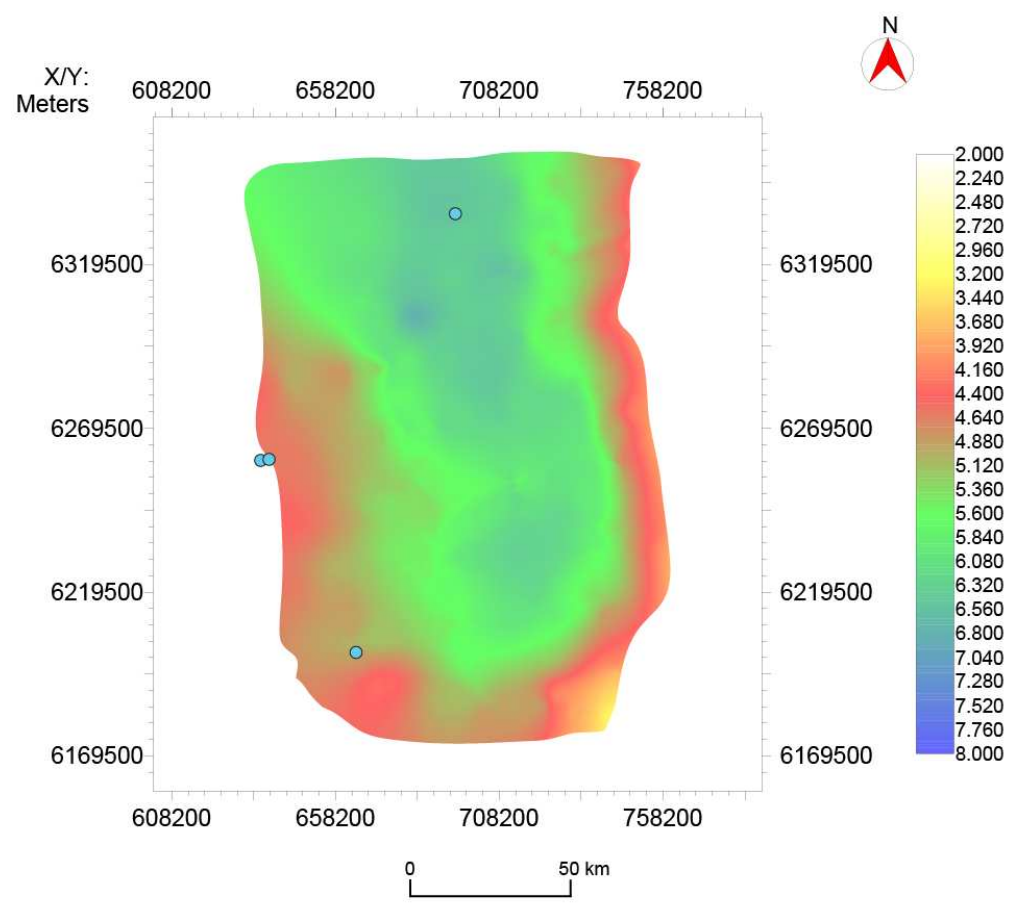

Figure 22. Shallow Valanginian Unconformity time structure map. The horizon has about $4.8 \mathrm{~s}$ of relief and shows a wider basin trough than the basalts horizon (Fig. 20). The east slope of the Mentelle Basin is steeper than the west slope. The unconformity shallows to the south and plunges to the north. The blue circles denote borehole locations, see Fig. 17.

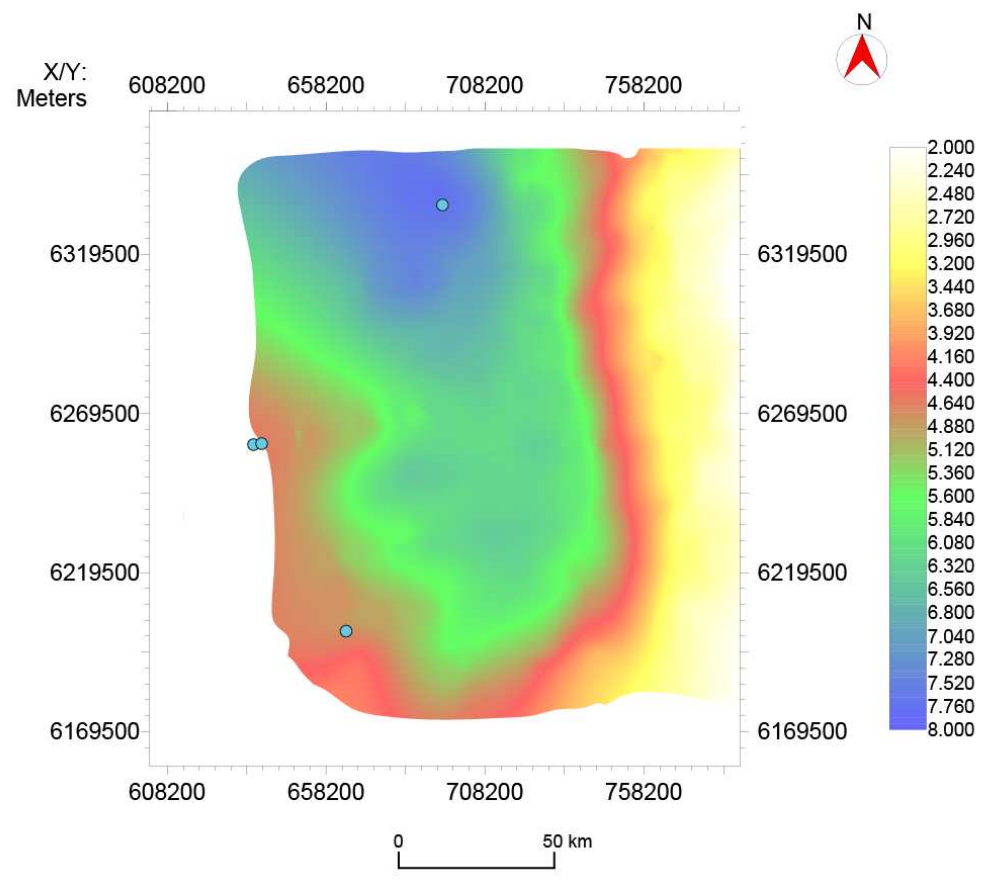

Figure 23. Likely Valanginian Unconformity time structure map. Six seconds of relief are shown here in the Mentelle Basin. This horizon shows a wider basin than the basalts horizon (Fig. 19). The east slope of the basin is steeper than the west, and the horizon shallows to the south and plunges to the north. The blue circles denote borehole locations, see Fig. 17. 
The isochore maps show that between the Aptian age (126 Ma) and present-day, sediment deposition was greatest off of the Yallingup Shelf in the eastern half of the MB and westward to the basin axis (Fig. 24). Between the time of basalt emplacement and the early Aptian, deposition of the volcaniclastic unit was relatively uniform on the eastern flank of the NP, thicker at the toe of the Yallingup Shelf in the southeast MB, and formed a narrow NNW-striking thickening trend across the basin axis (Fig. 25). Emplacement of basalts after the start of the Valanginian (139 Ma) age was greatest in the northern and SW MB (Figs. 26, 27). These two areas of greatest basalt deposition are separated by a thinner W-E striking feature. Basalt thickness generally decreases moving east across the basin before pinching out along the eastern slope. Deposition between the shallow and deeper possibilities of the Valanginian Unconformity (Fig. 28) shows a similar pattern to the interval between the likely Valanginian Unconformity and the Site U1513 basalt (Fig. 27).

Deposition was greatest between the Aptian and Valanginian ages in the northern MB and in a region SW of the basin axis (Fig. 29). Deposition increased in the eastern half of the basin relative to the western half between the Aptian and present day (Fig. 30). The northern and SW depocenters in the basin are separated by a W-E striking paleohigh (Figs. 10, 31). Large-scale (10 - $20 \mathrm{~km}$ width) basalt flows lie $\mathrm{N}$ and $\mathrm{S}$ of this paleohigh (Figs. 10, 31). 

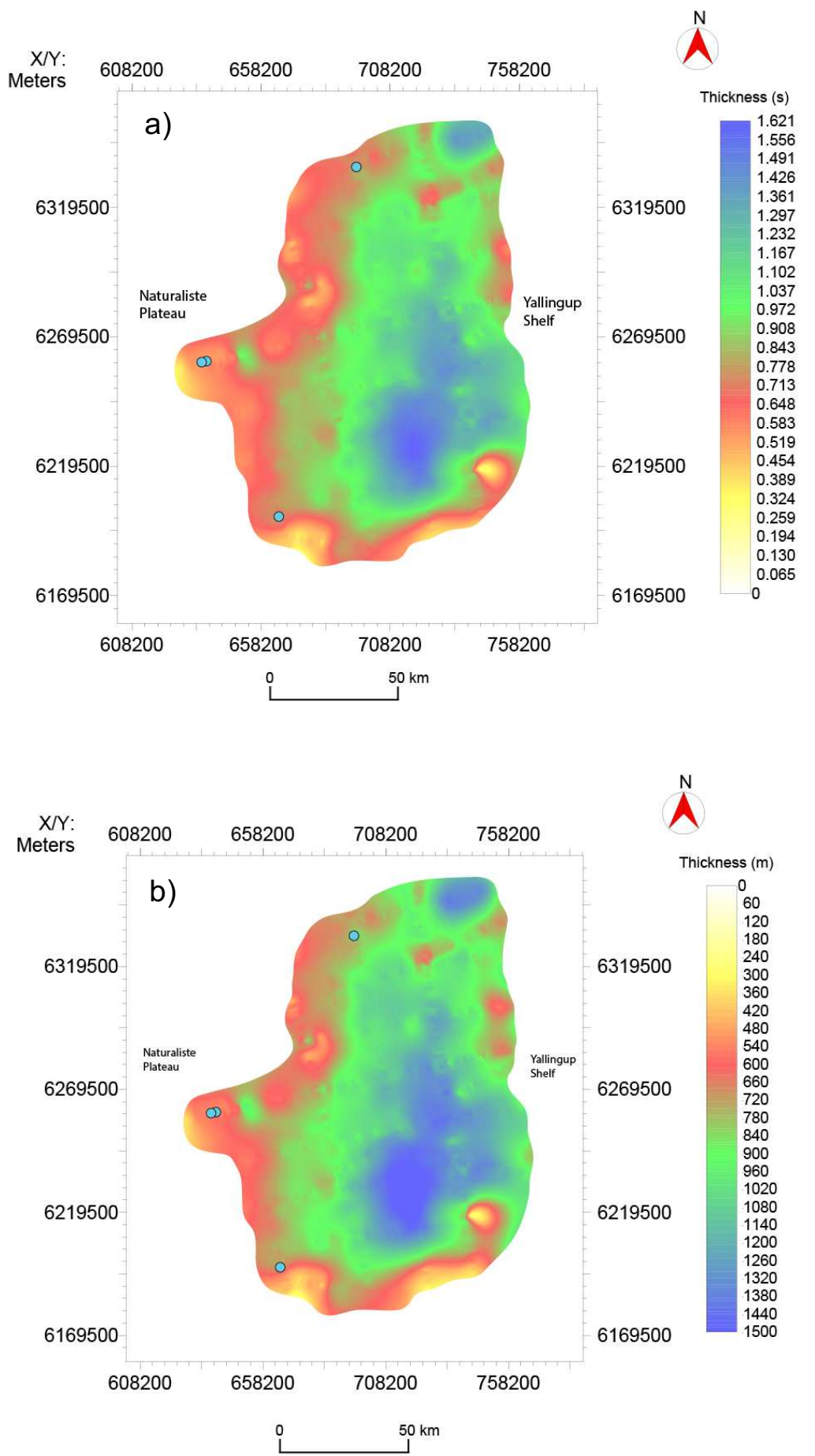

Figure 24. Seafloor to top of Unit 5 interval thickness. (a) Thickness is shown in time (s). (b) Thickness is shown in meters. The blue circles denote borehole locations. Starting from the south and moving clockwise: Hole U1516, DSDP 258, Hole U1513D, Hole U1514C. 

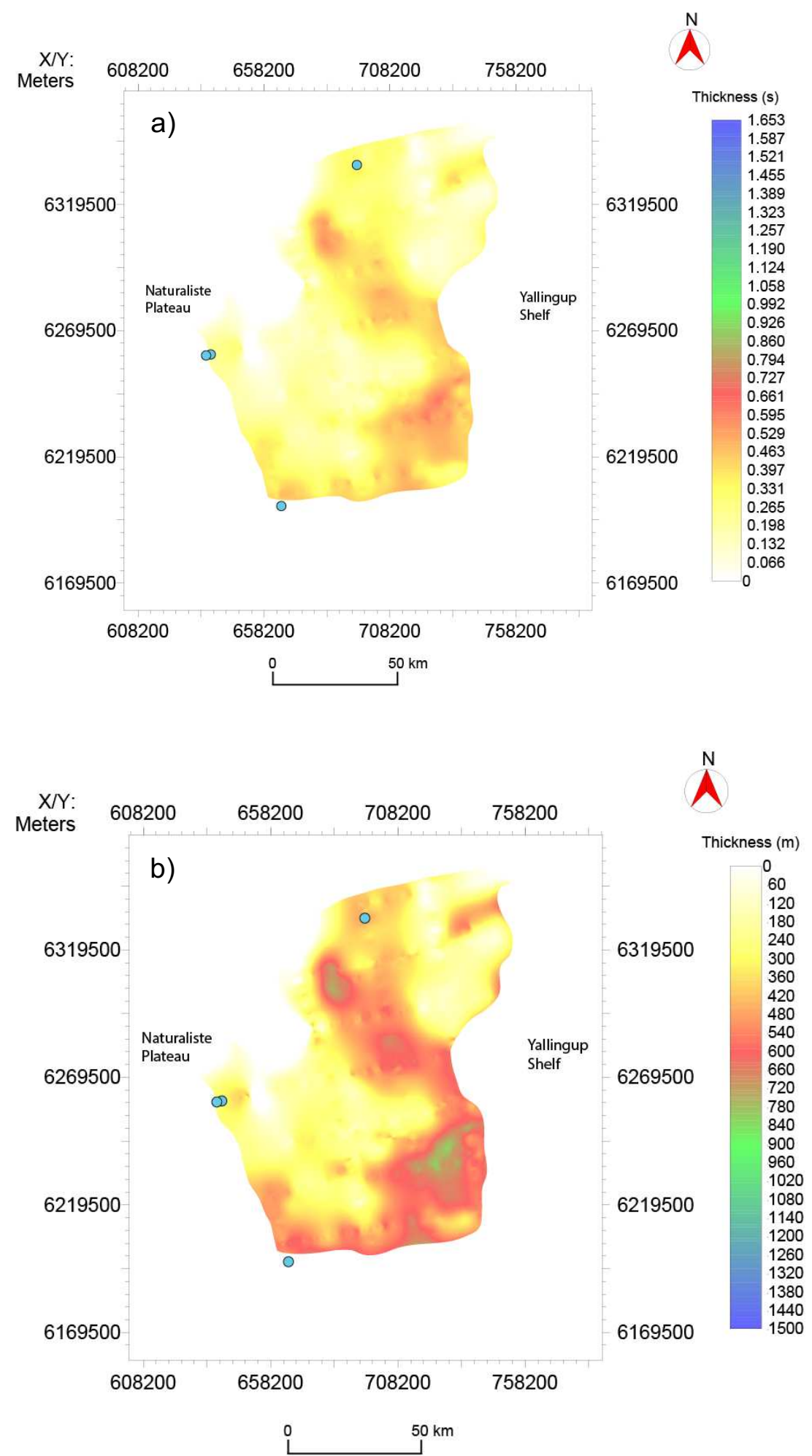

Figure 25. Interval thickness between top of volcaniclastic Unit 5 and Site U1513 basalts. (a) Thickness is shown in time (s). (b) Thickness is shown in meters. The blue circles denote the borehole locations. Starting from the south and moving clockwise: Hole U1516C, DSDP 258, Hole U1513D, Hole U1514C. 

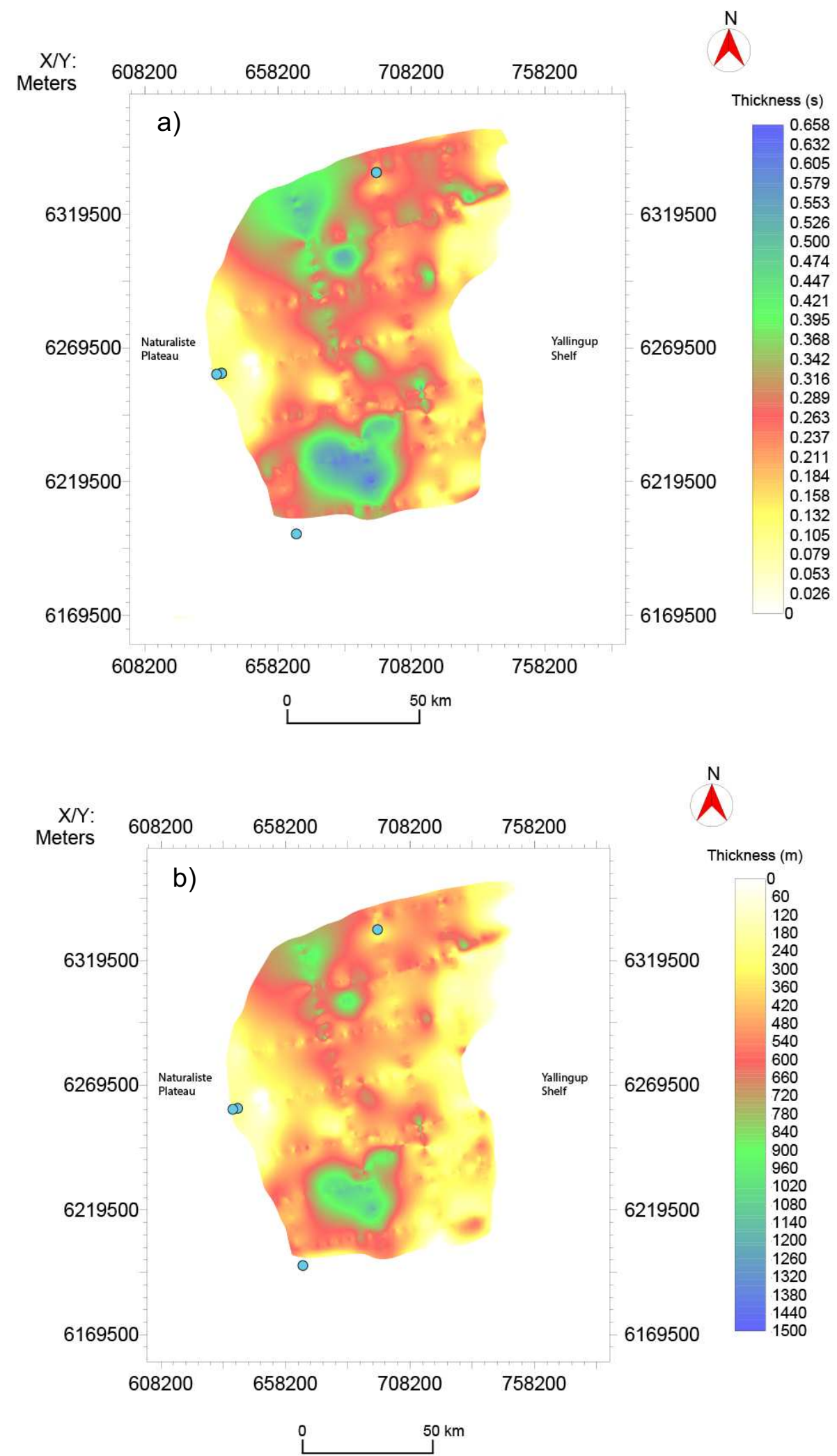

Figure 26. Site U1513 basalts to "shallow" Valanginian Unconformity interval thickness. (a) Thickness is shown in time (s). (b) Thickness is shown in meters. The numerous small features on the map that lie along the pattern of the seismic grid are due to the many small-scale faults that offset the mapped reflectors. The blue circles denote the borehole locations. Starting from the south and moving clockwise: Hole U1516C, DSDP 258, Hole U1513D, Hole U1514C. 

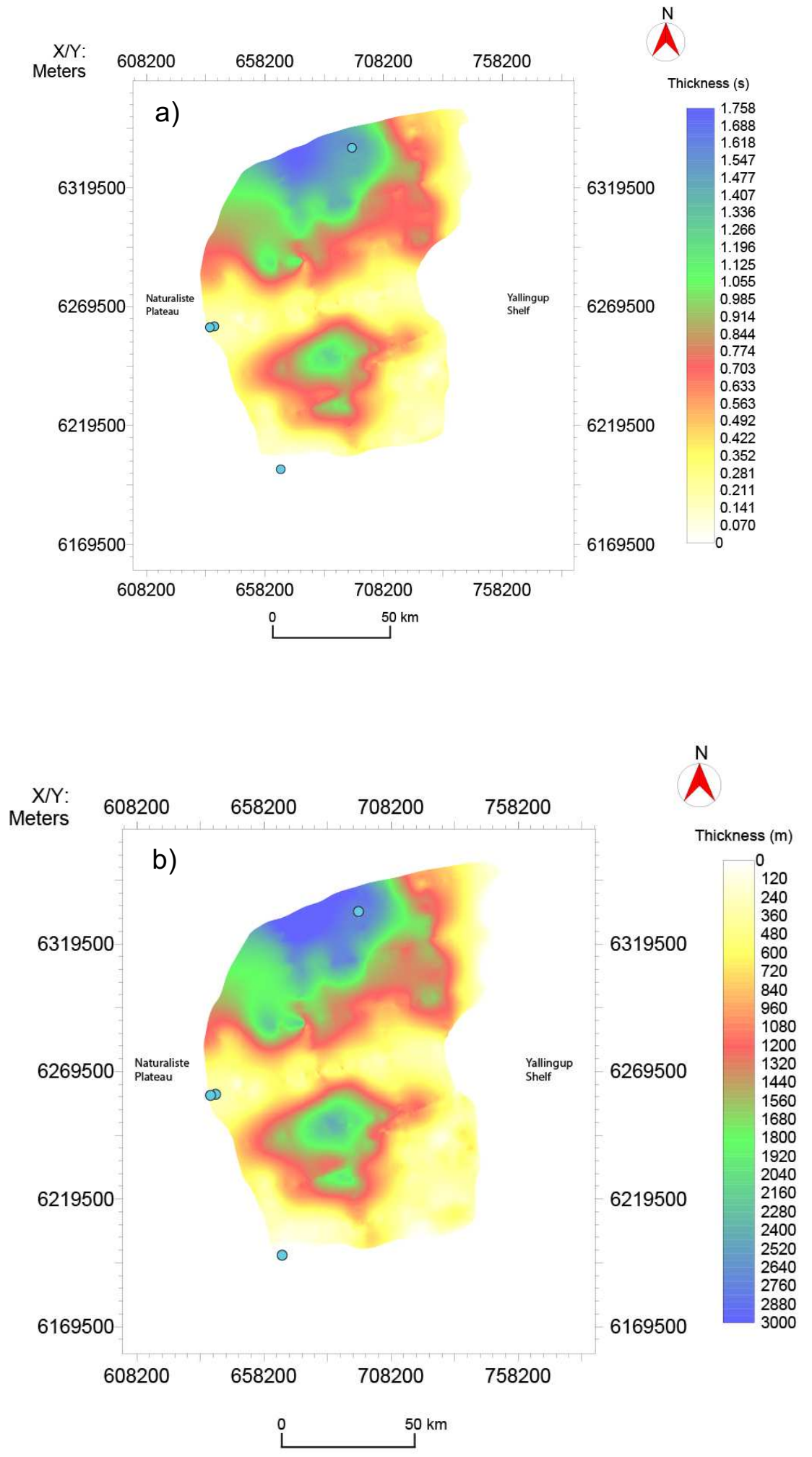

Figure 27. Basalts to likely Valanginian Unconformity interval thickness. (a) Thickness shown in time (s). (b) Thickness is shown in meters. Color bar saturates at $3000 \mathrm{~m}$ thickness. The blue circles denote the borehole locations. Starting from the south and moving clockwise: Hole U1516C, DSDP 258, Hole U1513D, Hole U1514C. 

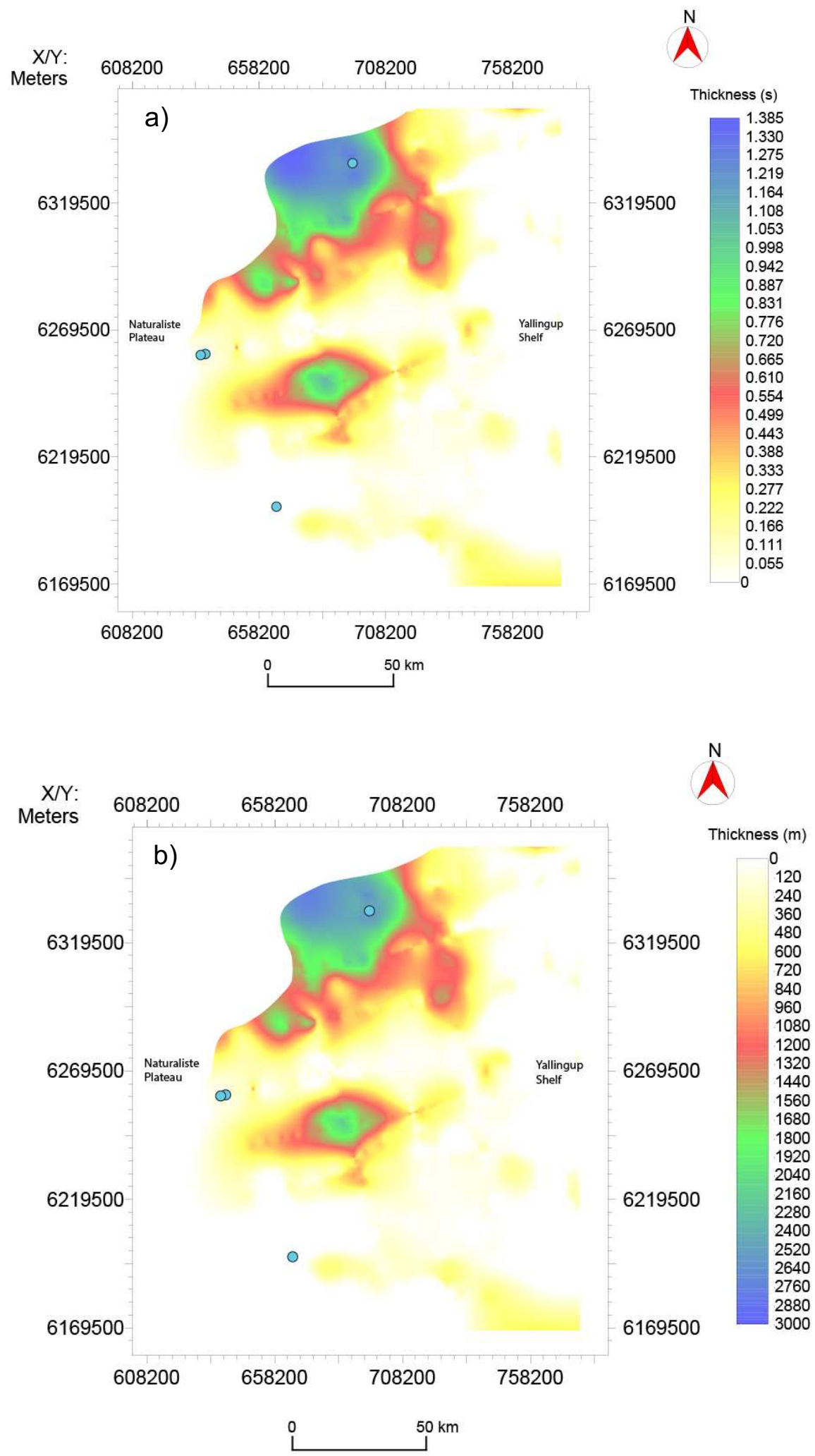

Figure 28. Shallow Valanginian to likely Valanginian Unconformity interval thickness. (a) Thickness is shown in time (s). (b) Thickness is shown in meters. The blue circles denote the borehole locations. Starting from the south and moving clockwise: Hole U1516C, DSDP 258, Hole U1513D, Hole U1514C. 


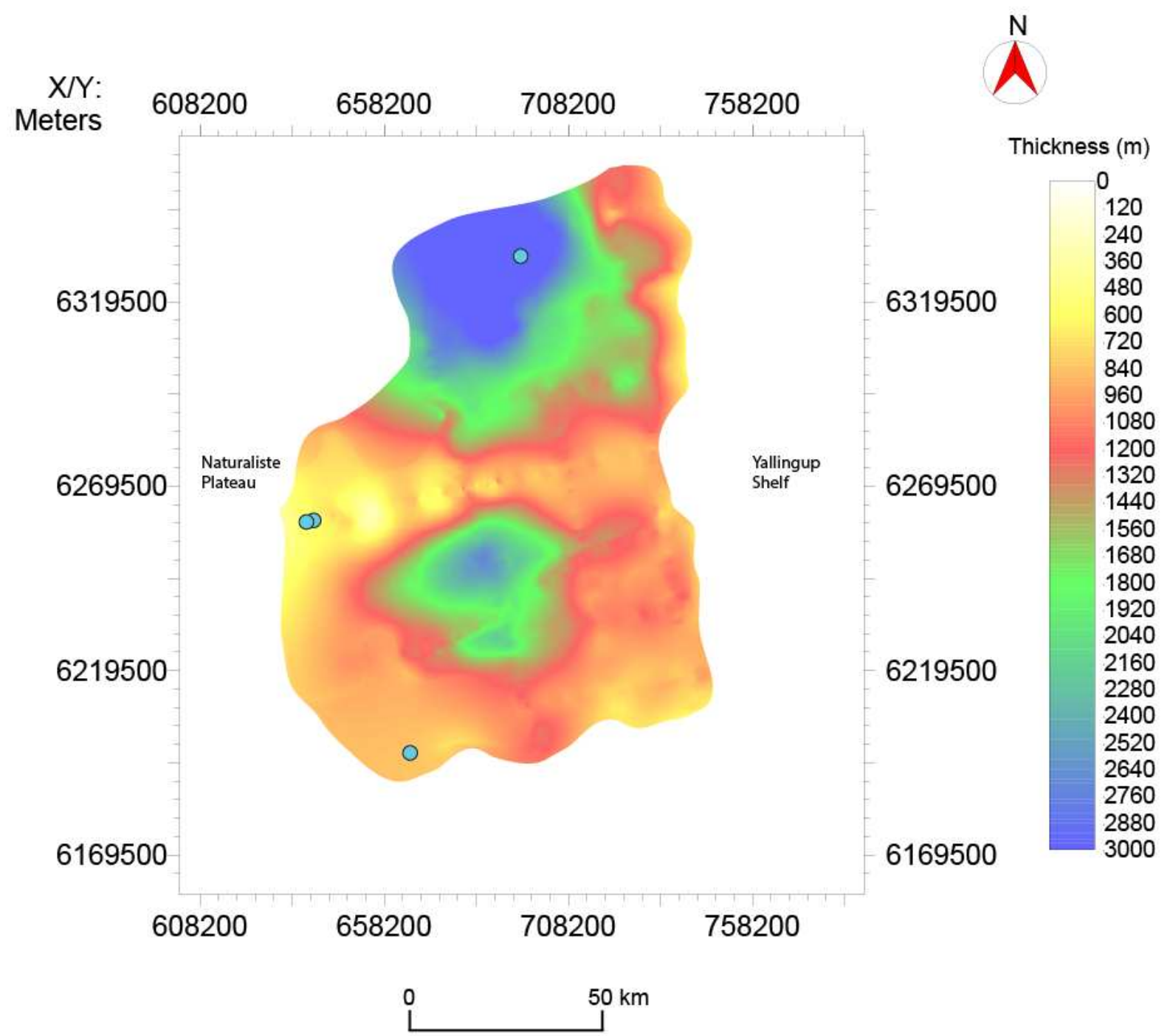

Figure 29. Interval thickness between top of Unit 5 and the likely Valanginian Unconformity. The color bar saturates at $3000 \mathrm{~m}$ thickness. The blue circles denote the borehole locations. Starting from the south and moving clockwise: Hole U1516C, DSDP 258, Hole U1513D, Hole U1514C. 


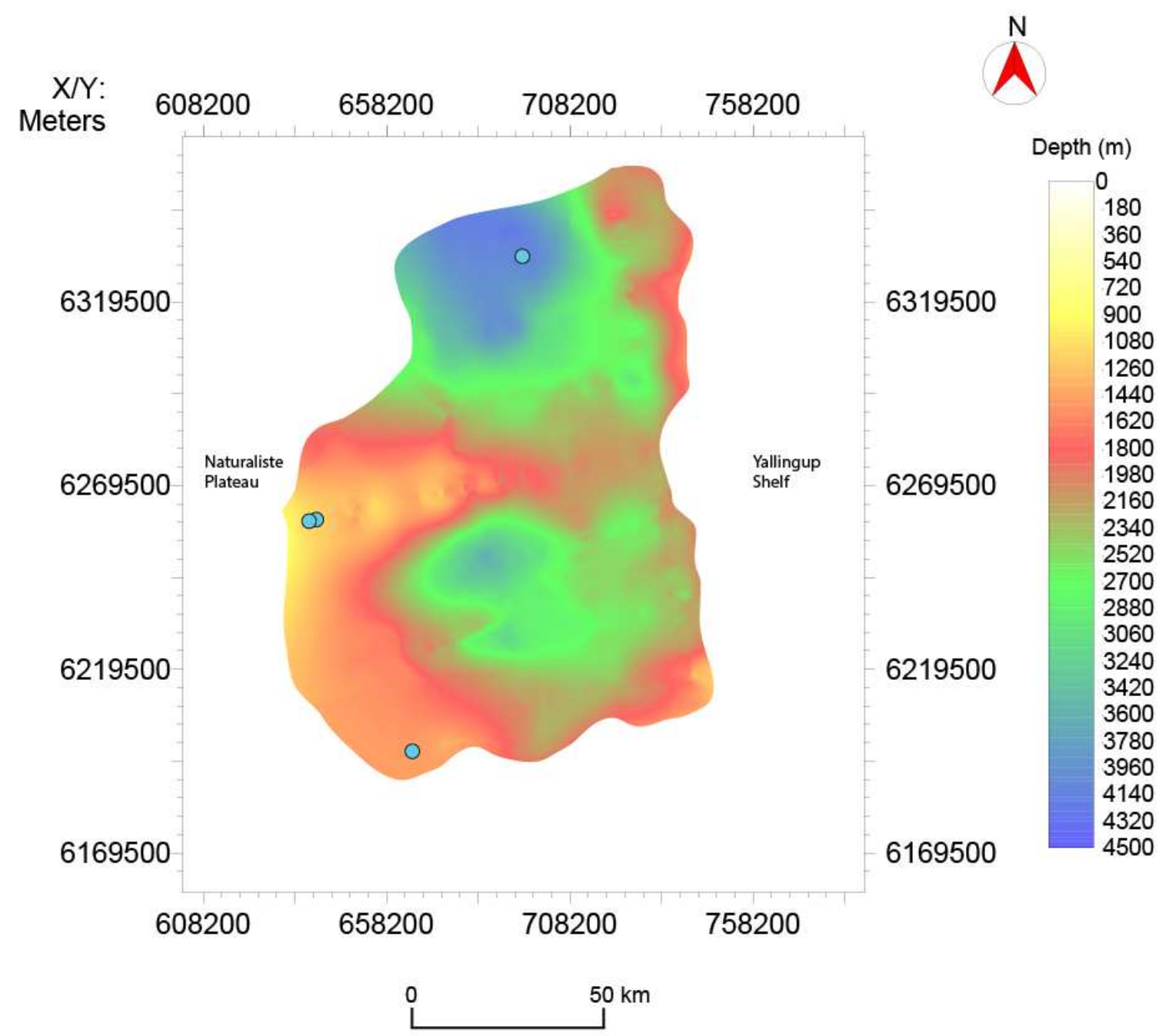

Figure 30. Interval thickness between seafloor and likely Valanginian Unconformity. The blue circles denote the borehole locations. Starting from the south and moving clockwise: Hole U1516C, DSDP 258, Hole U1513D, Hole U1514C. 


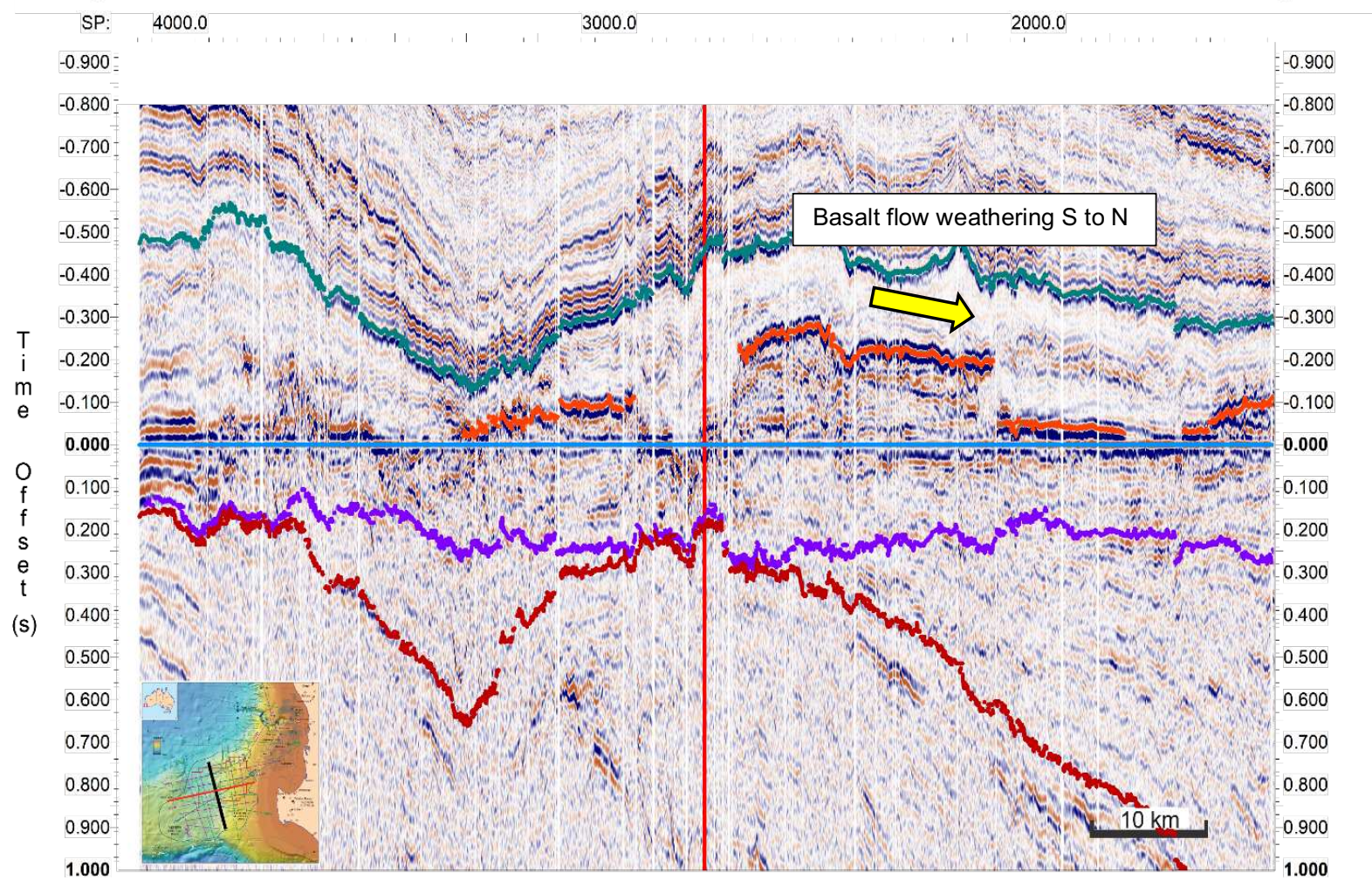

Figure 31. Paleohigh imaged on line S310_17. The basalt horizon (blue) was flattened to show the basin structure at the time of basalt emplacement. What are interpreted to be younger basalt flows (bright orange) are located both $\mathrm{N}$ and $\mathrm{S}$ of the paleohigh. Lateral changes $\mathrm{S}$ to $\mathrm{N}$ in reflector characteristics of the flows are interpreted to be due to weathering. The vertical red line through this seismic line marks the intersection of line S310_07 (Fig. 9). S310_07 lies along the W-E striking paleohigh. Locator map modified from Borissova et al., 2010. 


\section{CHAPTER V: INTERPRETATIONS AND DISCUSSION}

\section{Depositional Environments}

Weathering of strata between the Site U1513 basalt and the top of volcaniclastic Unit 5 implies that this interval was deposited above wavebase. The volcaniclastic strata of Unit 5 are underlain by basalt flows that extend from the eastern flank of the NP to the eastern slope of the MB. Volcanic activity was also present during the time of Unit 5 deposition, as evidenced by the volcanic flows and cones between the Valanginian Unconformity and the top of the volcaniclastic unit. However, volcanic activity slowed enough to where weathering and redistribution of the volcaniclastic strata took place during this same period, as shown by the downlapping reflector terminations west and east of the volcanic cone (Fig. 32). This pattern of deposition is interpreted to be strata weathering off of the sides of the cone and being deposited on the less steeply dipping surroundings. Other evidence of weathering is present throughout the basin (Fig. 33) on the basalt horizon. The reflector changes character from a higher amplitude continuous reflector to a lower amplitude sub-continuous reflector, which is interpreted to be weathering of the basalt flow and/or a lateral facies change.

The volcanic features are interpreted to have been emplaced between shallow water depths and above sea level. Volcanic units emplaced above sea level are able to flow over a distance, which are shown by the laterally extensive $(10-20 \mathrm{~km})$ basalt flows in the central Mentelle Basin (Figs. 10, 31, 32). Volcanic features emplaced underwater are cooled rapidly and not able to flow laterally (Fig. 34), resulting in a quenched volcanic cone.

After the basalt flows and volcanic features were emplaced close to sea level, physical and chemical weathering broke down the crystalline rock which then contributed to the volcaniclastic sediment being deposited at the time. Evidence for the volcaniclastic sediment mixing with other sediment types is present at Site U1513D, where volcaniclastic-rich sandstone interbedded with 
siltstones was penetrated (Huber et al., 2019b, Lee et al., 2020). I infer that the volcanic features were emplaced at shallow water depths or above sea level, and then weathered at or above sea level to form the volcaniclastic sequence in Unit 5 at Site U1513. This sequence was then buried by a marine transgression and deposition of the clay-rich deeper water strata of Unit 4 in boreholes U1513A and U1513D.

Besides the nannofossil-rich claystone of Unit 4 found above Unit 5 at Site U1513, evidence of a local marine transgression is present in the seismic data. For example, just below the top of Unit 5 (green) in Fig. 37, a reflector sequence onlapping to the north indicating local progradation is visible between a two-way travel time of 5.5 and 5.7 seconds. This pattern of reflectors terminating along an inclined surface is due to local sea-level rise (caused by either a global sea level rise or local subsidence outpacing sedimentation). In conjunction with the transition from volcaniclastic-rich sandstones interbedded with siltstones to deep-water black claystones at Site U1513, this reflector sequence provides evidence of local sea-level rise in the Mentelle Basin beginning before the Aptian (126 Ma) age. 


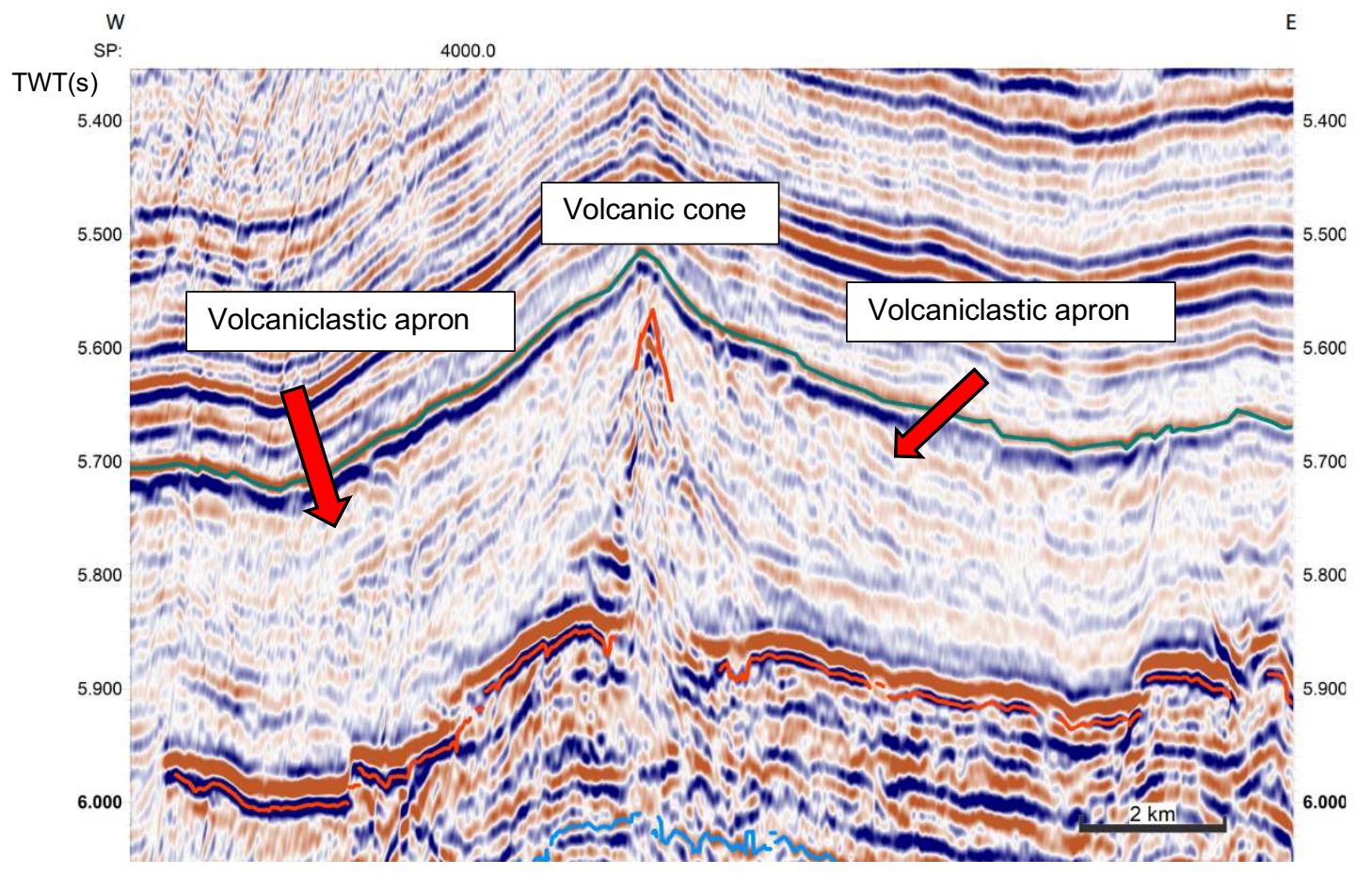

Figure 32. Erosional pattern on seismic line S310_07 (see Fig. 9 for location). Green horizon is top of volcaniclastic Unit 5, red signifies volcanic features, and blue horizon at bottom are basalts encountered at U1513D. West and east of the volcanic cone is erosional downlap off the cone onto strata above the mapped flow feature. 


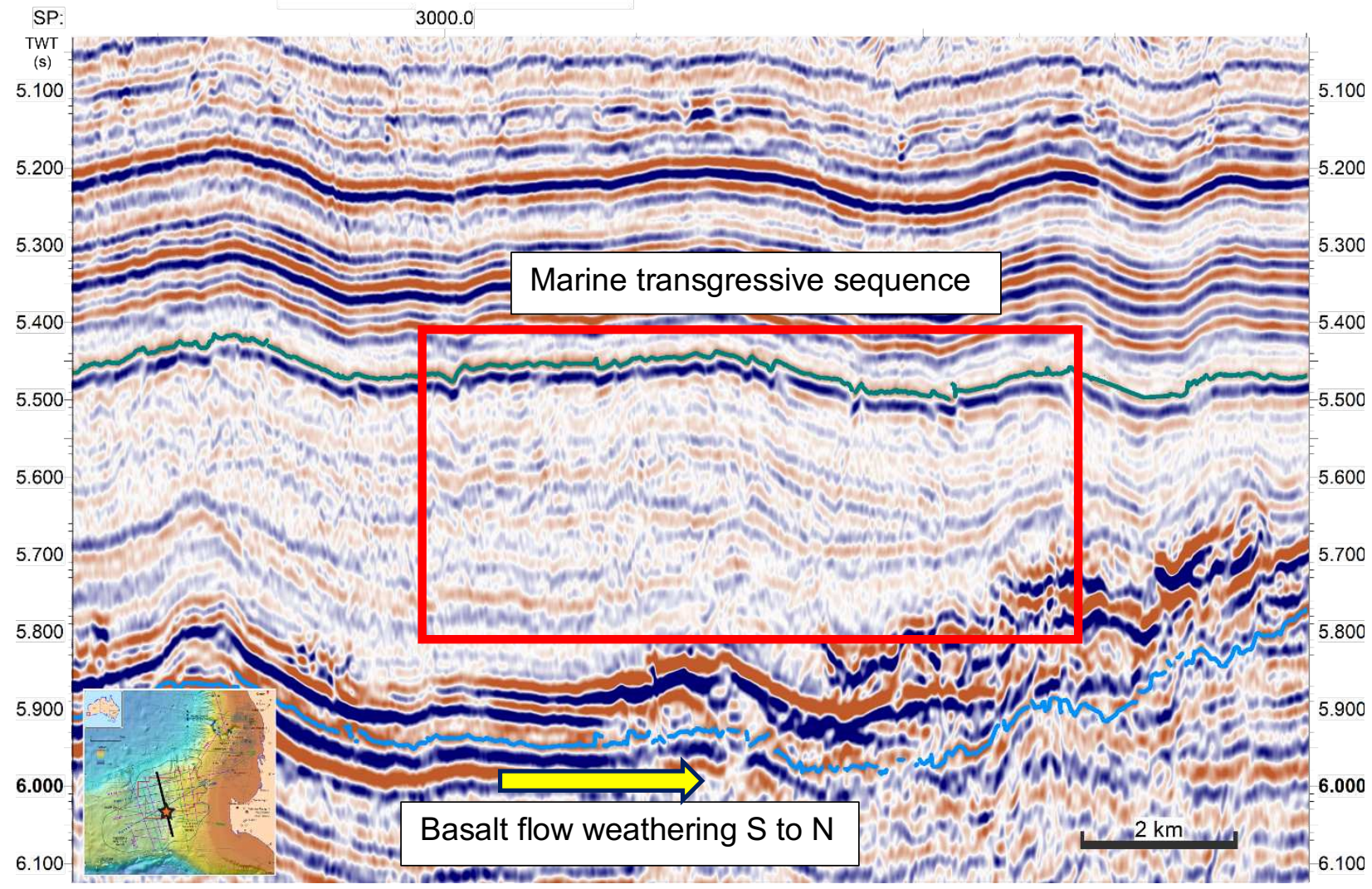

Figure 33. Stratigraphic onlap on line S310_16. The green horizon is the top of Unit 5 and the blue horizon signifies Site U1513 basalts. Onlapping reflector termination patterns are visible between 5.500 and 5.700 seconds. Also shown in the data here is the interfingering of younger basalt flows with the older basalts seen at U1513D. The basalts pictured here also show lateral changes in seismic character. Locator map modified from Borissova et al., 2010. 


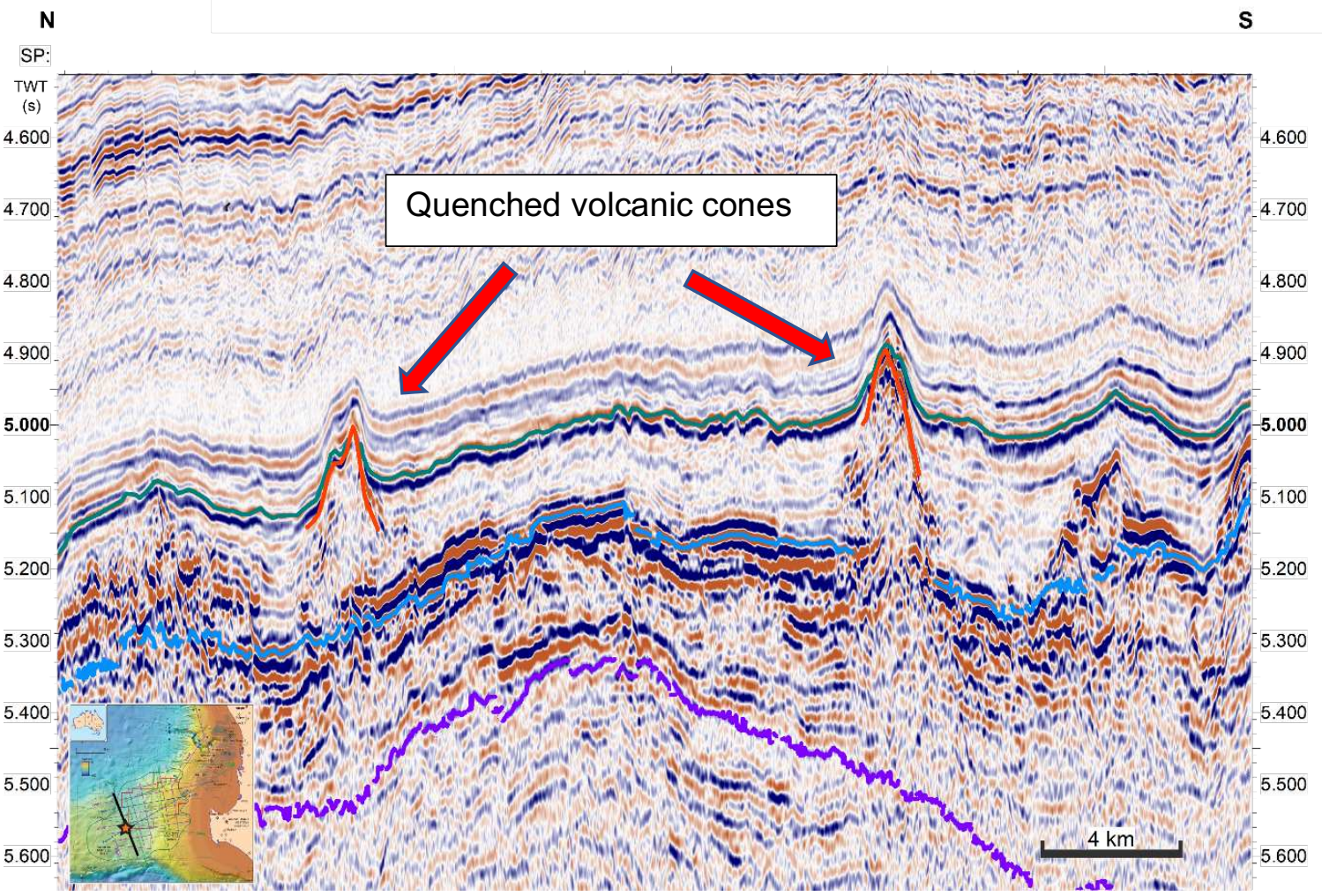

Figure 34. Volcanic features emplaced underwater. These volcanic cones (red) were rapidly cooled when exposed to the water, and therefore not allowed to expand laterally compared to flows emplaced above sea level (Figs. 35, 36). Top of Unit 5 shown in green, Site U1513 basalts in blue, and shallow Valanginian Unconformity in purple. Locator map modified from Borissova et al., 2010.

\section{Magmatism in the Mentelle Basin}

While magmatism occurred during breakup on the western Australian margin, as evidenced by the NP and Bunbury basalts west and east of the Mentelle Basin (Crostella and Backhouse, 2000; Borissova, 2002; Olierook et al., 2016; Direen et al., 2017), the duration and extent of magmatism is unclear in the MB itself. The seismic interpretation presented in Chapter IV places new constraints on both. The majority of the volcanic activity persisted after the late Valanginian (133 - $132 \mathrm{Ma}$ ) and ended before the Aptian (126 Ma), as the shallowest evidence of basalts and most volcanic features were mapped between the Valanginian Unconformity (even the shallowest interpretation) and the top of Unit 5. These volcanic features include 
smaller $(0.5-2.5 \mathrm{~km}$ wide $)$ cones and larger laterally continuous $(2-20 \mathrm{~km}$ wide) basaltic flows. While the basalt reflector mapped from U1513D corresponds with the end of basalt deposition on the eastern flank of the NP, younger basalt flows were imaged deeper in the basin. As the basalt reflector progressed eastward past Site U1513, it interfingers with younger basalt flows deeper in the MB, which also transition into low amplitude reflectors that are interpreted to be due to weathering. A few volcanic features were also mapped that crosscut the top of Unit 5, indicating some magmatic activity occurred after the Aptian age began. One particularly large example strikes NNW through the northern central region of the basin (Fig. 35). It appears as an $8-10 \mathrm{~km}$ wide cone-shaped (in cross section) feature that crosscuts all mapped horizons between the Valanginian and Aptian on the eastern slope of the MB. Due to the size of the feature, it is interpreted to be a post-Aptian incipient spreading center. 


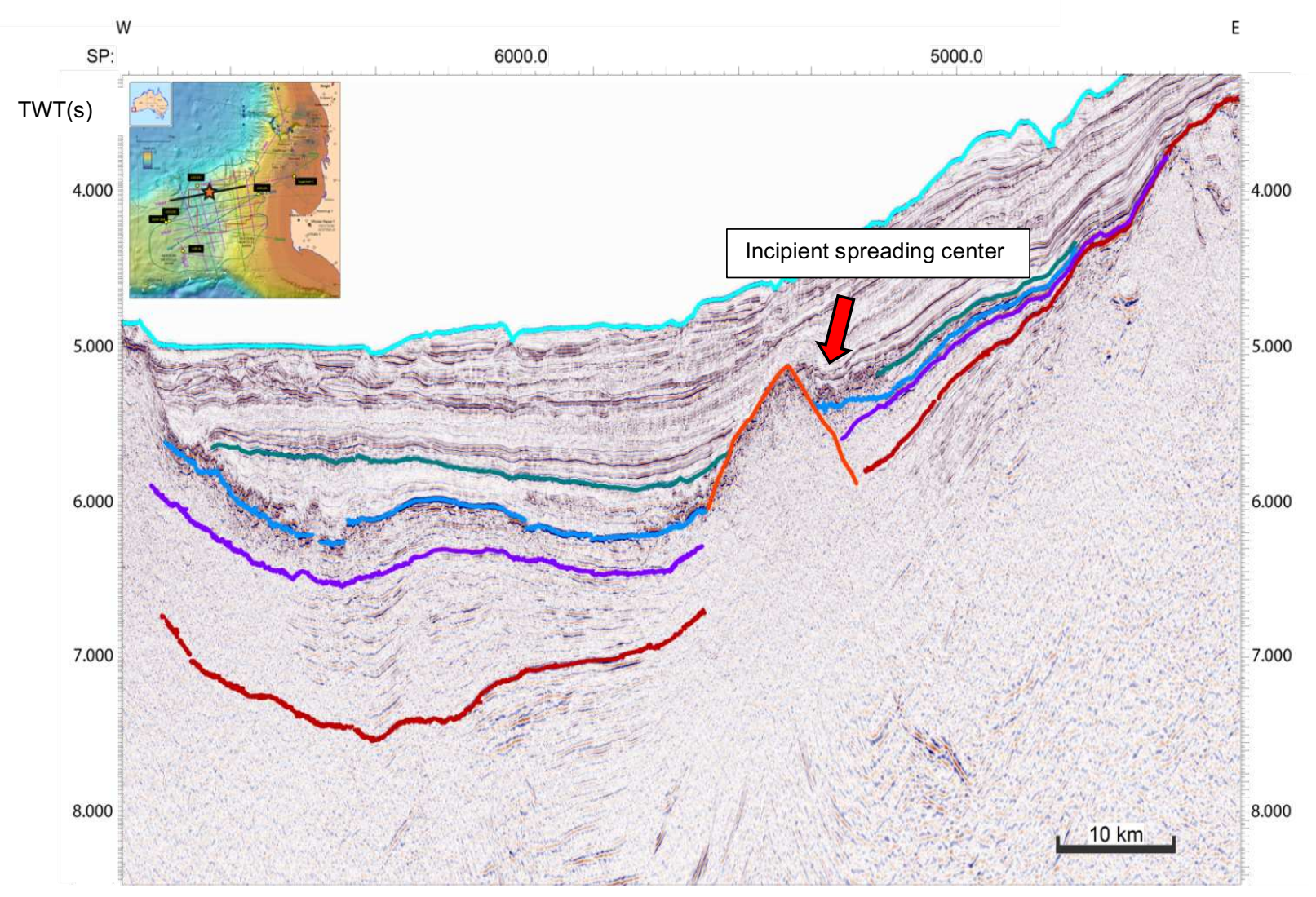

Figure 35. Incipient spreading center on line S310_03 in time domain. Horizons from top to bottom: seafloor (cyan), volcanic feature (orange/red), top of Unit 5 (dark green), basalts encountered at U1513D (blue), shallow Valanginian Unconformity possibility (purple), likely Valanginian Unconformity (dark red). Locator map in top left modified from Borissova et al., 2010.

The presence of basalts on the NP and western slope of the MB have been long known (Borissova et al., 2010; Direen et al., 2007; Huber et al., 2019b), but their eastern extent has been uncertain. Lee et al. (2020) suggested the basalts on the southwestern Australian margin were restricted to the NP and its buried eastern flank. In this study, reflectors interpreted to indicate basalt flows were mapped up to the toe of the eastern slope in the southern half of the basin (Fig. 9), and partway up the eastern slope in the northern half of the basin (Fig. 35). Thus, in this study the entirety of the MB is interpreted to have experienced basaltic volcanism at the time of breakup (with the exception of the eastern slop approaching the Yallingup Shelf). 


\section{Subsidence History}

Based on the isochore map (Fig. 29) between the top of Unit 5 and the likely Valanginian Unconformity horizon (encompassing strata deposited during the syn-rift to post-rift transition of breakup between India and Australia), we can infer that the MB subsided prior to the Naturaliste Plateau, which stayed at shelf depths until its breakup from the Indian plate (126 - $124 \mathrm{Ma})$. This is shown by the thick regions $(1800-3000+m)$ of strata in the center of the MB situated along the axis, while the western margin of the basin towards the NP is significantly thinner (400

$-800 \mathrm{~m}$ of thickness). The timing of the basin subsidence is inferred to begin no later than the late Valanginian (134 Ma), as the unconformity lies somewhere underneath the $134 \mathrm{Ma}$ Unit 5 strata at Site U1513. The isochore map between the seafloor and the likely Valanginian Unconformity (Fig. 34) has a similar structure to that of the interval between the top of the volcaniclastic strata and the unconformity, but also shows an increase in sedimentation on the eastern half of the basin. This implies that besides the increase in sedimentation on the eastern half of the Mentelle Basin, the broad subsidence pattern on the southwest Australian margin encompassing the MB and NP was relatively uniform after the start of the Aptian age (126 Ma). 


\section{CHAPTER VI: SUMMARY AND CONCLUSIONS}

This thesis investigated the subsidence and depositional history of the southwest Australian margin during the final stages of breakup from India between the Valanginian and early Aptian. The study concentrated on the volcanic sequences and overlying volcaniclastic strata (and its lateral equivalents) deposited in the MB between the onset of seafloor spreading on the PAP to the north $(>133-131 \mathrm{Ma})$ and the onset of spreading west of the NP (126 - $124 \mathrm{Ma}) .3630$ line-km of 2D multichannel seismic reflection data was used in conjunction with five IODP and DSDP boreholes to undertake this study.

The MB began to slowly subside with respect to the NP as extension occurred between Greater India and Australia-Antarctica during or prior to the Valanginian age. Overall subsidence between the Valanginian ( $>134 \mathrm{Ma}$ ) and start of the Aptian (126 Ma) ages was slow enough to keep the basin at or above shelf depths. Basalts and volcanic features were emplaced from the western slope to the eastern slope of the basin as rifting occurred between India and AustraliaAntarctica and continued after seafloor spreading began on the PAP (133 - $132 \mathrm{Ma})$ through the start of the Aptian age. These features were deposited between shelf depths and somewhere above sea level. Some were rapidly buried, preserving the volcanic architecture (e.g., Fig. 34), whereas others appear to have been exposed and weathered to create the surrounding volcaniclastic material (Figs. 32, 33). The weathered basalts interfinger with the

sedimentary strata (Unit 5), causing lateral changes in composition and reflection character from west to east in the MB. The rate of subsidence and sedimentation must have been similar, as the sediment was deposited at or above wave base, and/or reworked with volcaniclastics, and/or overlaid volcanic cones and flows before getting buried by a new layer. Following final breakup with India to the west of the NP (126 - $124 \mathrm{Ma})$, rapid subsidence of the NP and MB to middle bathyal to lower bathyal depths occurred, as evidenced by the transition from 
volcaniclastic sandstone (Unit 5) to Albian black nannofossil-rich claystones (Unit 4) at IODP Site U1513 (Lee et al., 2020). 


\section{REFERENCES}

Ball, P., Eagles, G., Ebinger, C., McClay, K., \& Totterdell, J. M. (2013). The spatial and temporal evolution of strain during the separation of Australia and Antarctica. Geochemistry, Geophysics, Geosystems, 14, 2771-2799. https://doi.org/10.1002/ggge.20160.

Besse, J., \& Courtillot, V. (1988). Paleogeographic maps of the continents bordering the Indian ocean since the early Jurassic. Journal of Geophysical Research, 93, 11791-11808. https://doi.org/10.1029/JB093iB10p11791.

Bodorkos, S., Fitzsimons, I. C. W., Hall, L. S., Sircombe, K. N. and Lewis, C. J. (2016). Beneath the Perth Basin: New U-Pb SHRIMP zircon ages from the Pinjarra Orogen, Western Australia, 2016. Record 2016/31. Geoscience Australia, Canberra. http://dx.doi.org/10.11636/Record.2016.031.

Borissova, I. (2002). Geological Framework of the Naturaliste Plateau, Geoscience Australia Record, 2002/20.

Borissova, I., Bradshaw, B., Nicholson, C., Struckmeyer, H., \& Payne, D. (2010). New exploration opportunities on the southwest Australian margin—deep-water frontier Mentelle Basin. The APPEA Journal, 50(1), 47-60.

Bradshaw, B. E., Rollet, N., Totterdell, J. M., \& Borissova, I. (2003). A revised structural framework for frontier basins on the southern and southwestern Australian continental margin, Geoscience Australia Record 2003/03 (p. 43). Canberra, Australia: Geoscience Australia.

Coffin, M. F., Pringle, M. S., Duncan, R. A., Gladzenko, T. P., Storey, M., Müller, R. D., \& Gahagan, L. A. (2002). Kerguelen hotspot magma output since $130 \mathrm{Ma}$. Journal of Petrology, 43, 1121-1139. https://doi.org/10.1093/petrology/43.7.1121.

Colwell, J. B., Symonds, P. A., \& Crawford, A. J. (1994). The nature of the Wallaby (Cuvier) Plateau and other igneous provinces of the west Australian margin. Journal of Australian Geology and Geophysics, 15, $137-156$.

Crostella, A., \& Backhouse, J. (2000). Geology and petroleum exploration of the central and southern Perth Basin, Western Australia (No. 57). Perth, WA: Geological Survey of Western Australia.

Davies, T. A., Luyendyk, B. P., et al., 1974, Initial Reports of the Deep Sea Drilling Project, Volume 26. Washington (U.S. Government Printing Office), 359-415. https:// doi:10.2973/dsdp.proc.26.111.1974.

Direen, N. G., Borissova, I., Stagg, H. M. J., Colwell, J.B., \& Symonds, P. A. (2007). Nature of the continent - ocean transition zone along the southern Australian continental margin: a comparison of the Naturaliste Plateau, SW Australia, and the central Great Australian Bight sectors. Imaging, Mapping and Modelling Continental Lithosphere Extension and Breakup, 235-263.

Direen, N. G., Stagg, H. M. J., Symonds, P. A., \& Colwell, J. B. (2011). Dominant symmetry of a conjugate southern Australian and East Antarctic magma-poor rifted margin segment. Geochemistry, Geophysics, Geosystems, 12, Q02006. https://doi.org/10.1029/2010GC003306 Dosso, L., Bougault, H., Beuzart, P., Calvez, J.-Y., \& Joron, J.-L. (1988). The geochemical structure of the South-East Indian Ridge. Earth and Planetary Science Letters, 88, 47-59. https://doi.org/10.1016/0012-821X(88)90045-3.

Direen, N.G., Stagg, H.M.J., Symonds, P.A., Norton, I.A. (2012). Variations in rift symmetry: cautionary examples from the Southern Rift System (Australia-Antarctica). Geological Society, London, Special Publications 369, 1-20. http://dx.doi.org/ 10.1144/SP369.4.

Direen, N. G., Cohen, B. E., Maas, R., Frey, F. A., Whittaker, J. M., Coffin, M. F., ... \& Crawford, A. J. (2017). Naturaliste Plateau: constraints on the timing and evolution of the Kerguelen Large Igneous Province and its role in Gondwana breakup. Australian Journal of Earth Sciences, 64(7), 851-869.

Frey, F. A., McNaughton, N. J., Nelson, D. R., \& Duncan, R. A. (1996). Petrogenesis of the Bunbury Basalt, Western Australia: Interaction between the Kerguelen plume and Gondwana lithosphere? Earth and Planetary Science Letters, 144, 163-183. https://doi. org/10.1016/0012-821X(96)00150-1. 
Frey, F. A., Coffin, M. F., Wallace, P. J., Weis, D., Zhao, X., Wise, S. W., Jr., et al. (2000). Origin and evolution of a submarine large igneous province: The Kerguelen Plateau and Broken Ridge, southern Indian Ocean. Earth and Planetary Science Letters, 176, 73-89. https://doi.org/10.1016/S0012-821X(99)00315-5.

Fullerton, L. G., Sager, W. W., \& Handschumacher, D. W. (1989). Late Jurassic-Early Cretaceous evolution of the eastern Indian Ocean adjacent to northwest Australia. Journal of Geophysical Research, 94, 2937-2953. https://doi.org/10.1029/JB094iB03p02937.

Gaina, C., Müller, R. D., Brown, B., Ishihara, T., \& Ivanov, S. (2007). Breakup and early seafloor spreading between India and Antarctica. Geophysical Journal International, 170, 151-169. https://doi.org/10.1111/j.1365246X.2007.03450.x.

Gibbons, A. D., U. Barckhausen, P. van den Bogaard, K. Hoernle, R. Werner, J. M. Whittaker, and R. D. Müller (2012), Constraining the Jurassic extent of Greater India: Tectonic evolution of the West Australian margin, Geochem. Geophys. Geosyst., 13, Q05W13, doi:10.1029/2011GC003919.

Gibbons, A. D., Whittaker, J. M., \& Müller, R. D. (2013). The breakup of East Gondwana: Assimilating constraints from Cretaceous ocean basins around India into a best-fit tectonic model. Journal of Geophysical Research: Solid Earth, 118, 808-822. https://doi.org/10.1002/ jgrb.50079.

Goncharov, A., \& Nelson, G. (2012). From two way time to depth and pressure for interpretation of seismic velocities offshore: Methodology and examples from the Wallaby Plateau on the West Australian margin. Tectonophysics, 572 573, 26-37. https://doi.org/10.1016/j. tecto.2012.06.037.

Hall, L. S., Gibbons, A. D., Bernardel, G., Whittaker, J., Nicholson, C., Rollet, N., \& Müller, R. D. (2013), Structural architecture of Australia's southwest continental margin and implications for Early Cretaceous basin evolution. In S. J. Moss \& M. Keep (Eds.), West Australian Basins Symposium (pp. 2-20). Perth, Australia: Petroleum Exploration Society of Australia.

Halpin, J. A., Crawford, A. J., Direen, N. G., Coffin, M. F., Forbes, C. J., \& Borissova, I. (2008). Naturaliste Plateau, offshore Western Australia: A submarine window into Gondwana assembly and breakup. Geology, 36(10), 807-810.

Halpin, J. A., Daczko, N. R., Direen, N. G., Mulder, R. C., \& Ishihara, T. (2020). Provenance of rifted continental crust at the nexus of East Gondwana breakup. Lithos, 354-355, 105363. https://doi.org/10.1016/..lithos.2019.105363.

Harrowfield, M., Holdgate, G. R., Wilson, C. J. L., \& McLoughlin, S. (2005). Tectonic significance of the Lambert graben, East Antarctica: Reconstructing the Gondwanan rift. Geology, 33, 197-200.

https://doi.org/10.1130/G21081.1.

Harris, L. B. (1994). Structural and tectonic synthesis for the Perth Basin, western Australia. Journal of Petroleum Geology, 17, 129-156. https://doi.org/10.1111/j.1747-5457.1994.tb00123.x.

Harry, D. L., Tejada, M. L. G., Lee, E. Y., Wolfgring, E., Wainman, C. C., Brumsack, H.-J., et al. (2020). Evolution of the Southwest Australian rifted continental margin during breakup of East Gondwana: Results from International Ocean discovery program expedition 369. Geochemistry, Geophysics, Geosystems, 21, e2020GC009144. https://doi. org/10.1029/2020GC009144.

Heine, C., \& Müller, R. (2005). Late Jurassic rifting along the Australian North West Shelf: margin geometry and spreading ridge configuration. Australian Journal of Earth Sciences, 52, 27-39.

https://doi.org/10.1080/08120090500100077.

Huber, B.T., Hobbs, R.W., Bogus, K.A., Batenburg, S.J., Brumsack, H.-J., do Monte Guerra, R., Edgar, K.M., Edvardsen, T., Garcia Tejada, M.L., Harry, D.L., Hasegawa, T., Haynes, S.J., Jiang, T., Jones, M.M., Kuroda, J., Lee, E.Y., Li, Y.-X., MacLeod, K.G., Maritati, A., Martinez, M., O'Connor, L.K., Petrizzo, M.R., Quan, T.M., Richter, C., Riquier, L., Tagliaro, G.T., Wainman, C.C., Watkins, D.K., White, L.T., Wolfgring, E., and Xu, Z. (2019a). Site U1512. In Hobbs, R.W., Huber, B.T., Bogus, K.A., and the Expedition 369 Scientists, Australia Cretaceous Climate and Tectonics. Proceedings of the International Ocean Discovery Program, 369: College Station, TX (International Ocean Discovery Program). https://doi.org/10.14379/iodp.proc.369.103.2019

Huber, B.T., Hobbs, R.W., Bogus, K.A., Batenburg, S.J., Brumsack, H.-J., do Monte Guerra, R., Edgar, K.M., Edvardsen, T., Garcia Tejada, M.L., Harry, D.L., Hasegawa, T., Haynes, S.J., Jiang, T., Jones, M.M., Kuroda, J., Lee, E.Y., Li, Y.-X., MacLeod, K.G., Maritati, A., Martinez, M., O'Connor, L.K., Petrizzo, M.R., Quan, T.M., Richter, C., 
Riquier, L., Tagliaro, G.T., Wainman, C.C., Watkins, D.K., White, L.T., Wolfgring, E., and Xu, Z. (2019b). Site U1513. In Hobbs, R.W., Huber, B.T., Bogus, K.A., and the Expedition 369 Scientists, Australia Cretaceous Climate and Tectonics. Proceedings of the International Ocean Discovery Program, 369: College Station, TX (International Ocean Discovery Program). https://doi.org/10.14379/iodp.proc.369.104.2019

Huber, B.T., Hobbs, R.W., Bogus, K.A., Batenburg, S.J., Brumsack, H.-J., do Monte Guerra, R., Edgar, K.M., Edvardsen, T., Garcia Tejada, M.L., Harry, D.L., Hasegawa, T., Haynes, S.J., Jiang, T., Jones, M.M., Kuroda, J., Lee, E.Y., Li, Y.-X., MacLeod, K.G., Maritati, A., Martinez, M., O'Connor, L.K., Petrizzo, M.R., Quan, T.M., Richter, C., Riquier, L., Tagliaro, G.T., Wainman, C.C., Watkins, D.K., White, L.T., Wolfgring, E., and Xu, Z. (2019c). Site U1514. In Hobbs, R.W., Huber, B.T., Bogus, K.A., and the Expedition 369 Scientists, Australia Cretaceous Climate and Tectonics. Proceedings of the International Ocean Discovery Program, 369: College Station, TX (International Ocean Discovery Program). https://doi.org/10.14379/iodp.proc.369.105.2019

Huber, B.T., Hobbs, R.W., Bogus, K.A., Batenburg, S.J., Brumsack, H.-J., do Monte Guerra, R., Edgar, K.M., Edvardsen, T., Garcia Tejada, M.L., Harry, D.L., Hasegawa, T., Haynes, S.J., Jiang, T., Jones, M.M., Kuroda, J., Lee, E.Y., Li, Y.-X., MacLeod, K.G., Maritati, A., Martinez, M., O’Connor, L.K., Petrizzo, M.R., Quan, T.M., Richter, C., Riquier, L., Tagliaro, G.T., Wainman, C.C., Watkins, D.K., White, L.T., Wolfgring, E., and Xu, Z. (2019d). Site U1515. In Hobbs, R.W., Huber, B.T., Bogus, K.A., and the Expedition 369 Scientists, Australia Cretaceous Climate and Tectonics. Proceedings of the International Ocean Discovery Program, 369: College Station, TX (International Ocean Discovery Program). https://doi.org/10.14379/iodp.proc.369.106.2019

Huber, B.T., Hobbs, R.W., Bogus, K.A., Batenburg, S.J., Brumsack, H.-J., do Monte Guerra, R., Edgar, K.M., Edvardsen, T., Garcia Tejada, M.L., Harry, D.L., Hasegawa, T., Haynes, S.J., Jiang, T., Jones, M.M., Kuroda, J., Lee, E.Y., Li, Y.-X., MacLeod, K.G., Maritati, A., Martinez, M., O'Connor, L.K., Petrizzo, M.R., Quan, T.M., Richter, C., Riquier, L., Tagliaro, G.T., Wainman, C.C., Watkins, D.K., White, L.T., Wolfgring, E., and Xu, Z. (2019e). Site U1516. In Hobbs, R.W., Huber, B.T., Bogus, K.A., and the Expedition 369 Scientists, Australia Cretaceous Climate and Tectonics. Proceedings of the International Ocean Discovery Program, 369: College Station, TX (International Ocean Discovery Program). https://doi.org/10.14379/iodp.proc.369.107.2019

Ingle, S., Weis, D., Scoates, J. S., \& Frey, F. A. (2002). Relationship between the early Kerguelen plume and continental flood basalts of the paleo-Eastern Gondwanan margins. Earth and Planetary Science Letters, 197, 35-50. https://doi.org/10.1016/S0012-821X(02)00473-9.

Ingle, S., Scoates, J., Weis, D., Brügmann, G., \& Kent, R. (2004). Origin of Cretaceous continental tholeiites in southwestern Australia and eastern India: Insights from Hf and Os isotopes. Chemical Geology, 209, 83-106. https://doi.org/10.1016/i.chemgeo.2004.04.023.

Kent, R. (1991). Lithospheric uplift in eastern Gondwana: evidence for a long-lived mantle plume system. Geology, 19, 19-23. https://doi. org/10.1130/0091-7613(1991)0192.3.CO;2.

Kent, R. W., Pringle, M. S., Müller, R. D., Saunders, A. D., \& Ghose, N. C. (2002). 40Ar/39Ar geochronology of the Rajmahal basalts, India, and their relationship to the Kerguelen Plateau. Journal of Petrology, 43, 1141-1153. https://doi.org/10.1093/petrology/43.7.1141.

Kinny, P. D., \& Nutman, A. P. (1996). Zirconology of the Meeberrie gneiss, Yilgarn Craton, Western Australia: an early Archaean migmatite. Precambrian Research, 78(1-3), 165-178.

Lawver, L. A., Gahagan, L. M., \& Coffin, M. F. (1992). The development of paleoseaways around Antarctica. In J. P. Kennett \& D. A. Warkne (Eds.), The Antarctic paleoenvironment: Perspectives on global change: Part one (pp. 7-30). Washington, DC: American Geophysical Union.

Lech, M. E., Jorgensen, D. C., Southby, C., Wang, L., Nguyen, V., Borissova, I., \& Lescinsky, D. (2016). Palaeogeographic mapping to understand the hydrocarbon and CO2 storage potential of the post-rift Warnbro Group, offshore Vlaming Sub-basin, southern Perth Basin, Australia. Marine and Petroleum Geology, 77, $1206-1226$.

Lee, E. Y., Wolfgring, E., Tejada, M. L. G., Harry, D. L., Wainman, C. C., Chun, S. S., ... \& Party, S. (2020). Early Cretaceous subsidence of the Naturaliste Plateau defined by a new record of volcaniclastic-rich sequence at IODP Site U1513. Gondwana Research, 82, 1-11.

Mahoney, J. J., Jones, W. B., Frey, F. A., Salters, V. J. M., Pyle, D. G., \& Davies, H. L. (1995). Geochemical characteristics of lavas from Broken Ridge, the Naturaliste Plateau and southernmost Kerguelen Plateau: Cretaceous 
plateau volcanism in the southeast Indian Ocean. Chemical Geology, 120, 315-345. https://doi.org/10.1016/00092541(94)00144-W.

Maritati, A., Danisik, M., Halpin, J. A., Whittaker, J. M., \& Aitken, A. R. A. (2020). Pangea rifting shaped the East Antarctic Landscape. Tectonics, 39, e2020TC006180. https://doi.org/10.1029/2020TC006180.

Markl, R. G. (1978). Evidence for the early Cretaceous breakup of Gondwanaland off southwestern Australia. Marine Geology, 26, 41-48. https://doi.org/10.1016/0025-3227(78)90044-0.

Markwitz, V., Kirkland, C. L., \& Evans, N. J. (2017). Early Cambrian metamorphic zircon in the northern Pinjarra Orogen: Implications for the structure of the West Australian Craton margin. Lithosphere, 9(1), 3-13.

Mihut, D., \& Müller, R. D. (1998). Volcanic margin formation and Mesozoic rift propagators in the Cuvier Abyssal Plain off Western Australia. Journal of Geophysical Research: Solid Earth, 103(B11), 27135-27149.

Müller, R. D., C. Gaina, A. Tikku, D. Mihut, S. Cande, and J. M. Stock (2000), Mesozoic/Cenozoic tectonic events around Australia, in The History and Dynamics of Global Plate Motions, Geophys. Monogr. Ser., vol. 121, edited by M. A. Richards, R. G. Gordon, and R. D. van der Hilst, pp. 161-188, AGU, Washington, D. C., doi:10.1029/ GM121p0161.

Mutter, J.C., Hegarty, K.A., Cande, S.C. and Weissel, J.K.. 1985. Breakup between Australia and Antarctica: a brief review in the light of new data, In: E.S. Husebye, G.L. Johnson and Y. Kristoffersen (Editors), Geophysics of the Polar Regions. Tectonophysics, 114: 255-279.

Nicholson, C., Borissova, I., Krassay, A., Boreham, C., Monteil, E., Neumann, V., ... \& Bradshaw, B. (2008). New exploration opportunities in the southern Vlaming Sub-basin. The APPEA Journal, 48(1), 371-380.

Norton, I. O., \& Sclater, J. G. (1979). A model for the evolution of the Indian Ocean and the breakup of Gondwanaland. Journal of Geophysical Research, 84, 6803-6830. https://doi.org/10.1029/JB084iB12p06803.

Norvick, M. S. (2004). Tectonic and stratigraphic history of the Perth Basin, Geoscience Australia Record 2004/16 (p. 30). Canberra, Australia: Geoscience Australia.

Olierook, H. K. H., Merle, R. E., Jourdan, F., Sircombe, K., Faser, G., Timms, N. E., et al. (2015). Age and geochemistry of magmatism on the oceanic Wallaby Plateau and implications for the opening of the Indian Ocean. Geology, 43, 971-974. https://doi.org/10.1130/G37044.1.

Olierook, H. K. H., Jourdan, F., Merle, R. E., Timms, N. E., Kusznir, N., \& Muhling, J. R. (2016). Bunbury Basalt: Gondwana breakup products or earliest vestiges of the Kerguelen mantle plume? Earth and Planetary Science Letters, 440, 20-32. https://doi.org/10.1016/j. epsl.2016.02.008.

Olierook, H. K. H., Merle, R. E., \& Jourdan, F. (2017). Toward a Greater Kerguelen large igneous province: Evolving mantle source contributions in and around the Indian Ocean. Lithos, 282-283, 163-172.

https://doi.org/10.1016/j.lithos.2017.03.007.

Owens, R. J., Borissova, I., Hall, L. S., Bernardel, G., Southby, C., Grosjean, E., \& Mitchell, C. (2018). Extensional during rifting direction Geology and prospectivity of the northern Houtman Sub basin, Geoscience Australia Record 2018/25. Canberra, Australia: Geoscience Australia.

Planke, S., P. A. Symonds, and C. Berndt (2002), Volcanic rifted margin structure and development: A comparison between the NE Atlantic and western Australian continental margins, paper 90022 presented at AAPG Hedberg Conference, Stavanger, Norway, 8-11 Sept.

Plumb, K. A. (1979). The tectonic evolution of Australia. Earth Science Reviews, 14, 205-249. https://doi.org/10.1016/0012-8252(79)90001-1.

Powell, C. M., Roots, S. R., \& Veevers, J. J. (1988). Pre-breakup continental extension in East Gondwanaland and the early opening of the eastern Indian Ocean. Tectonophysics, 155, 261-283. https://doi.org/10.1016/00401951(88)90269-7. 
Robb, M. S., Taylor, B., \& Goodliffe, A. M. (2005). Re-examination of the magnetic lineations of the Gascoyne and Cuvier Abyssal Plains, off NW Australia. Geophysical Journal International, 163, 42-55.

https://doi.org/10.1111/i.1365-246X.2005.02727.x.

Royer, J.-Y., \& Sandwell, D. T. (1989). Evolution of the eastern Indian ocean since the Late Cretaceous: Constraints from GEOSAT altimetry. Journal of Geophysical Research, 94, 13755-13782. https://doi.org/10.1029/JB094iB10p13755.

Song, T., \& Cawood, P. S. (2000). Structural styles in the Perth Basin associated with the Mesozoic break-up of Greater India and Australia. Tectonophysics, 317, 55-72. https://doi.org/10.1016/S0040-1951(99)00273-5.

Storey, M., Saunders, A. D., Tarney, J., Gibson, I. L., Norry, M. J., Thirlwall, M. F., et al. (1989). Contamination of Indian Ocean asthenosphere by the Kerguelen-Heard mantle plume. Nature, 338, 574-576. https://doi.org/10.1038/338574a.

Symonds, P. A., Planke, S., Frey, O., \& Skogseid, J. (1998). Volcanic evolution of the Western Australian continental margin and its implications for basin development.

Tejada, M. L. G., Lee, E. Y., Chun, S. S., Harry, D. L., Riquier, L. Wainman, C. C. (2020), Data report: Petrology and volcanic stratigraphy at Site U1513, IODP Expedition 369 (Vol. 369, Australia Cretaceous climate and tectonics). Proceedings of the International Ocean Discovery Program, International Ocean Discovery Program, College Station, TX. https://doi.org/10.14379/iodp.proc.369.202.2020.

Totterdell, J.M., Blevin, J.E., Struckmeyer, H.I.M., Bradshaw, B.E., Colwell, J.B., Kennard, J.M. (2000). A new sequence framework for the Great Australian Bight: starting with a clean slate. The APPEA Journal 40, 95-117.

Veevers, J. J. (2006). Updated Gondwana (Permian-Cretaceous) earth history of Australia. Gondwana Research, 9 , 231-260. https://doi. org/10.1016/j.gr.2005.11.005.

Wainman, C. C., Borissova, I., Harry, D. L., Hobbs, R. W., Mantle, D. J., Maritati, A., ... \& the Expedition 369 Scientists. (2020). Evidence for non-marine Jurassic to earliest Cretaceous sediments in the pre-breakup section of the Mentelle Basin, southwestern Australia. Australian Journal of Earth Sciences, 67(1), 89-105.

Weaver, S. D., Storey, B. C., Pankhurst, R. J., Mukasa, S. B., DiVenere, V. J., \& Bradshaw, J. D. (1994). AntarcticaNew Zealand rifting and Marie Byrd Land lithospheric magmatism linked to ridge subduction and mantle plume activity. Geology, 22(9), 811-814.

White, L. T., Gibson, G. M., \& Lister, G. S. (2013). A reassessment of paleogeographic reconstructions of eastern Gondwana: Bringing geology back into the equation. Gondwana Research, 24, 984-998. https://doi.org/10.1016/i.gr.2013.06.009.

Whitechurch, H., Montigny, R., Sevigny, J., Storey, M., \& Salters, V. (1992). K-Ar and 40Ar-39Ar ages of central Kerguelen Plateau basalts (Vol. 120, pp. 71-77). Proceedings of the Ocean Drilling Program, Scientific Results, Ocean Drilling Program, College Station, TX.

Whittaker, J. M., Williams, S. E., Halpin, J. A., Wild, T. J., Stilwell, J. D., Jourdan, F., \& Daczko, R. (2016). Eastern Indian Ocean microcontinent formation driven by plate motion changes. Earth and Planetary Science Letters, 454, 203-212. https://doi.org/10.1016/j. epsl.2016.09.019.

Williams, S. E., Whittaker, J. M., Granot, R., \& Müller, R. D. (2013). Early India-Australia spreading history revealed by newly detected Mesozoic magnetic anomalies in the Perth Abyssal Plain. Journal of Geophysical Research: Solid Earth, 118, 3275-3284. https://doi. org/10.1002/jgrb.50239.

Yeates, A. N., Bradshaw, M. T., Dickins, J. M., Brakel, A. T., \& Exon, N. F. (1987). The Westralian superbasin: an Australian link with Tethys. In International Symposium on Shallow Tethys 2 (pp. 199-213).

Zhou, Q., Liu, Z., Lai, Y., Wang, G.-C., Liao, Z., Li, Y.-X., et al. (2017). Petrogenesis of mafic and felsic rocks from the Comei large igneous province, South Tibet: Implications for the initial activity of the Kerguelen plume. Geological Society of America Bulletin, 130, 811-824. https://doi.org/10.1130/B31653.1.

Zhu, D. -C., Mo, X., Pan, G., Zhao, Z., Dong, G., Shi, Y., et al. (2008). Petrogenesis of the earliest Early Cretaceous mafic rocks from the Cona area of the eastern Tethyan Himalaya in south Tibet: Interaction between the incubating 
Kerguelen plume and the eastern Greater India lithosphere? Lithos, 100, 147-175.

https://doi.org/10.1016/j.lithos.2007.06.024.

Zhu, D.-C., Chung, S.-L., Mo, X.-X., Zhao, Z.-D., Niu, Y., Song, B., \& Yang, Y.-H. (2009). The 132 Ma Comei-

Bunbury large igneous province: Remnants identified in present-day southeastern Tibet and southwestern Australia. Geology, 37, 583-586. https://doi.org/10.1130/ G30001A.1. 